Cristiane Martins Moulin de Moraes

\title{
Avaliação de aspectos da resposta imune de pacientes com obesidade grau III antes e após cirurgia bariátrica
}

Tese apresentada à Faculdade de Medicina da Universidade de São Paulo para obtenção do título de Doutor em Ciências

Área de concentração: Endocrinologia Orientador: Prof. Dr. Alfredo Halpern 
Cristiane Martins Moulin de Moraes

\section{Avaliação de aspectos da resposta imune de pacientes com obesidade grau III antes e após cirurgia bariátrica}

Tese apresentada à Faculdade de Medicina da Universidade de São Paulo para obtenção do título de Doutor em Ciências

Área de concentração: Endocrinologia Orientador: Prof. Dr. Alfredo Halpern 


\title{
Dados Internacionais de Catalogação na Publicação (CIP)
}

\author{
Preparada pela Biblioteca da
}

Faculdade de Medicina da Universidade de São Paulo

Creprodução autorizada pelo autor

Moraes, Cristiane Martins Moulin de

Avaliação de aspectos da resposta imune de pacientes com obesidade grau III antes e após cirurgia bariátrica / Cristiane Martins Moulin de Moraes. -- São Paulo, 2008.

Tese(doutorado)--Faculdade de Medicina da Universidade de São Paulo. Departamento de Clínica Médica.

Área de concentração: Endocrinologia.

Orientador: Alfredo Halpern.

Descritores: 1.Obesidade 2.Cirurgia bariátrica 3.Imunidade 4.Células matadoras naturais 


\section{DEDICATÓRIA}

Dedico este trabalho às três pessoas mais importantes na minha vida:

minha mãe Emy,

minha madrinha Nilciléa

e meu padrinho Antônio Cezar.

Pelo amor incomensurável e altruísmo absoluto, que me fizeram crescer e me fortalecer sempre. 


\section{AGRADECIMENTOS}

A Deus sempre, especialmente pela saúde e por ter colocado tantas pessoas especiais em meu caminho.

Aos pacientes participantes deste estudo, que, por meios próprios e com toda simplicidade, saíram de suas casas para esta colaboração.

Ao Professor Dr. Luiz Vicente Rizzo, meu querido e muito admirado orientador, por abrir as portas de seu laboratório para realização deste estudo e pelo seu precioso (e disputado!) tempo dispensado para me ajudar do início ao fim deste trabalho. Você sabe que lhe sou eternamente grata!

Ao Professor Dr. Alfredo Halpern, meu outro (e não menor!) orientador, pela oportunidade de aprendizagem, influência importante na minha formação profissional e científica e pela confiança que depositou em $\operatorname{mim}$.

Aos amigos Ivo Marguti (menino Ivo!) e Jean Pierre S. Peron (João Pedro!), pela solidariedade, carinho e paciência nas etapas de realização dos experimentos e elaboração de pôsteres e artigo (e os outros frutos que foram gerados e os que virão deste trabalho).

Ao restante do pessoal do Laboratório de Imunologia, em especial, Luciana, Ricardo, Lilia, Julieta, Rafael (valeu pelo CD com o Prism!) e Luiz (ótima a explicação da citometria de fluxo!), pela acolhida e toda ajuda fornecida.

Ao pessoal do Hospital São Cristóvão, em especial, Dr. José Renato Cohn e Dr. Enéas Rocco, por terem permitido a realização de parte da coleta no hospital, e pelo estímulo constante.

À Eliana Vergílio, pelo mais pronto auxílio, pessoalmente, por via email e telefone, com as questões burocráticas e outras pendências para as quais eu precisei de alguém para resolver.

À Prof ${ }^{a}$ Anna Myrna Jaguaribe de Lima, por sua ajuda à distância com gráficos e algumas outras questões da tese, e por sua torcida e amizade.

À $\mathrm{Dr}^{\mathrm{a}}$ Cíntia Cercato, pelo apoio (e por intermediar com o ocupado chefinho!) desde meu início no Hospital das Clínicas.

Às "meninas" nutricionistas Alessandra Rodrigues e Lourença Dalcanale, pela revisão dos assuntos sobre os quais vocês são bem entendidas.

Às minhas outras especiais "meninas" Daniela Telo, Maria Edna de Melo, Heide Lui Reinhardt e Rebeca Bedone (amo muito tudo isto!), além das várias outras queridas "meninas" que estão ou que passaram pelo 
Grupo de Obesidade e Síndrome Metabólica neste meu período de pósgraduação e ao "menino" Dr. Marcio Mancini, por me proporcionarem um ambiente de trabalho descontraído. A força e a amizade de cada um de vocês foram indispensáveis para a conclusão deste trabalho.

À minha banca do exame de qualificação, Prof ${ }^{a}$ Valquíria Bueno, Prof $^{a}$ $\operatorname{Dr}^{a}$ Ana Cláudia Latrônico e $\operatorname{Prof}^{a}{ }^{2} r^{a}$ Márcia Nery, pelos elogios, críticas construtivas e valiosas sugestões.

A Danilo Marcelo Leite do Prado e a sua tia Regina, pelo auxílio na reta final e pela generosa revisão.

À $\operatorname{Dr}^{a}$ Ivani Maria P. B. Caruso, por auxiliar na organização dos meus pensamentos, ajudando a encontrar a luz em vários períodos escuros.

A Luís Antônio G. Benegas, por ter me levado a São Paulo, e pelo incentivo a me manter na minha luta profissional.

Aos meus amigos, que mesmo à distância, sempre me motivaram com sua valiosa torcida.

Além dos meus familiares, aos quais dedico este trabalho, aos meus outros familiares, por todo apoio, amor e carinho, e por sempre vibrarem com todas minhas pequenas conquistas, sem quererem nada em troca.

Àqueles que tiveram participação direta ou indireta na conclusão deste trabalho e que, porventura, tenham sido omitidos.

Por fim, agradeço a FAPESP - Fundação de Amparo à Pesquisa do Estado de São Paulo - pelo apoio financeiro para a realização deste estudo.

Cumpro uma etapa muito importante de minha vida, que me trouxe (além de algumas rugas!) muitas felicidades e grande crescimento profissional e emocional. 


\section{SUMÁRIO}

\section{LISTA DE ABREVIATURAS}

LISTA DE SÍMBOLOS

LISTA DE TABELAS

LISTA DE FIGURAS

RESUMO

SUMMARY

1. INTRODUÇÃO

1.1 Visão geral do sistema imune............................................. 3

1.2 Relação entre função imune e obesidade ........................ 15

1.3 Tecido adiposo como órgão pró-inflamatório.................... 17

1.4 Efeitos dos nutrientes sobre o sistema imune................ 20

1.5 Efeitos da perda de peso induzida por dieta sobre o

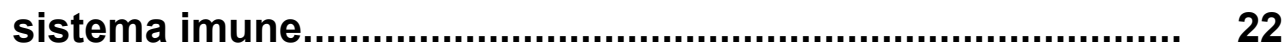

1.6 Perda de peso induzida por cirurgia bariátrica e efeitos potenciais no sistema imune................................................ 24

2. OBJETIVOS

3. CASUÍSTICA E MÉTODOS........................................................ 31

3.1 Casuística e critérios de inclusão....................................... 32

3.2 Critérios de exclusão......................................................... 33

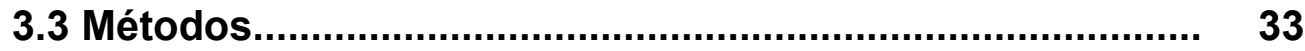

3.3.1 Exames laboratoriais................................................ 36 
3.3.2 Avaliação imunológica ............................................... $\quad 38$

3.4 Análise estatística............................................................. 49

4. RESULTADOS ........................................................................ 51

4.1 Peso corporal e exames laboratoriais............................. 52

4.2 Parâmetros imunológicos.............................................. 53

4.2.1 Ensaio de proliferação de linfócitos T em presença de mitógeno

4.2.2 Produção de citocinas por células mononucleares após estimulação com mitógeno.

4.2.3 Fenotipagem de populações celulares mononucleares obtidas do sangue periférico por citometria de fluxo.

4.2.4 Atividade citotóxica de células NK.......................... 64

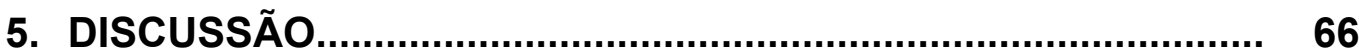

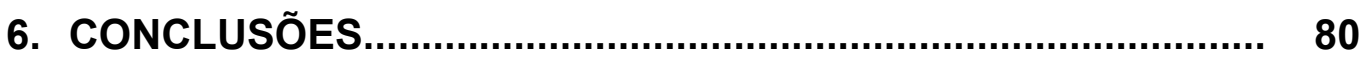

7. ANEXOS............................................................................ 82

8. REFERÊNCIAS BIBLIOGRÁFICAS........................................ 87 


\section{LISTA DE ABREVIATURAS}

ABTS- ácido 2,2'-azino-bis-(3-etilbenzotiazolina)-6-sulfônico

ASP- Proteína Estimuladora da Acilação

BGA- Banda Gástrica Ajustável

CAA- Células Apresentadoras de Antígenos

CD- Grupo de Diferenciação

Col- Colesterol

CT- Colesterol Total

Cy- Cy-Cromo

DGJYR- Derivação Gastrojejunal e Reconstrução em Y de Roux

DMEM- Meio de Eagle Modificado por Dulbecco

DNA- Ácido Desoxiribonucleico

ELISA- Ensaio de Imunoadsorção Ligado à Enzima

FITC- Isotiocianato de Fluoresceína

FL- Fluorocromo

FSC- "Forward Light Scatter"

GVB- Gastroplastia Vertical com Bandagem

HDL- Lipoproteína de Alto Peso Molecular

HRPO- Peroxidase de Rabanete Selvagem

IDR- Ingestão Diária Recomendada

IE- Índice de Estimulação

IFN- Interferon

Ig- Imunoglobulina

IL- Interleucina 
IMC- Índice de Massa Corpórea

JAK- Quinase Tirosina Janus

Kcal- Quilocalorias

LDH- Desidrogenase Láctica

LDL- Lipoproteína de Baixo Peso Molecular

Ltda- Limitada

MHC- Complexo Principal de Histocompatibilidade

NK- Natural Killer

OPD- ø-Fenileno-Diamina

PBMC- Células Mononucleares de Sangue Periférico

PBS- Solução Salina Tamponada

PCR- Proteína C Reativa

PE- Ficoeritrina

PHA- Fitohemaglutinina

Rpm- Rotações por Minuto

RPMI- Meio de Cultura Roswell Park Memorial Institute

SSC- "Side Scatter"

STAT- Transdutor de Sinal e Ativador de Transcrição

Tc- T citotóxico

TG- Triglicerídeos

Th- T "helper"

TNF- Fator de Necrose Tumoral

VLCD- Dieta com Muito Baixas Calorias

VR- Valor de Referência 
a- alfa

$\beta$ - beta

$\gamma$-gama

$\mu-$ micro

${ }^{\circ} \mathrm{C}$ - graus Celsius

\%- por cento

d- deci

g- grama

$g$ - força gravitacional

$\mathrm{H}$ - comprimento de onda

kg- quilograma

L- litro

mg- miligrama

mM- milimolar

mL- mililitro

m- metro

M- molar

n- nano

>- maior que

$<-$ menor que 


\section{LISTA DE TABELAS}

Tabela 1. Composição das principais vitaminas e minerais contidos no polivitamínico Materna ${ }^{\circledR}$ e a ingestão diária recomendada para

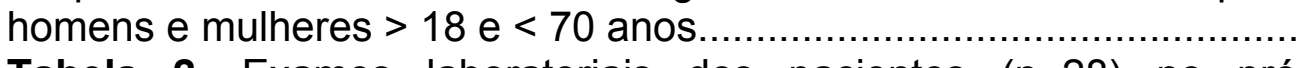
Tabela 2. Exames laboratoriais dos pacientes $(n=28)$ no préoperatório e seis meses após a cirurgia... 


\section{LISTA DE FIGURAS}

Figura 1. Principais células envolvidas nas respostas imunes.

Figura 2. O papel das citocinas na diferenciação e na função efetora de linfócitos T e células NK

Figura 3. Representação esquemática de um citômetro de fluxo........

Figura 4. Diagrama em "dot plot" da distribuição de células obtidas de sangue periférico segundo análise de tamanho (FSC) e granulosidade (SSC).

Figura 5. Representação esquemática da placa de cultura de células para a realização do ensaio de células NK.

Figura 6. Dados antropométricos dos pacientes $(n=28)$ no préoperatório e seis meses após a cirurgia. * teste t de Student.

Figura 7. Expressão em "dot plot" do índice de estimulação (IE) dos pacientes $(n=28)$ no pré-operatório e seis meses após a cirurgia.

Figura 8. Expressão em "dot plot" das concentrações de citocinas produzidas por células mononucleares dos pacientes $(n=28$, exceto para IL-2 e IL-12 cujo $n=27$ ) no pré-operatório e seis meses após a cirurgia

Figura 9. Número absoluto de pacientes que apresentaram redução ou aumento (por faixa percentual de aumento: $<10 \%$, entre $10-25 \%$, entre $25-50 \%$ e $>50 \%$ ) nas concentrações das citocinas produzidas por PBMC após estímulo com PHA.

Figura 10A. Expressão em "dot plot" dos marcadores de superfície de populações celulares avaliados por citometria de fluxo no préoperatório e seis meses após cirurgia. Os dados são representativos da porcentagem da população de linfócitos Th (CD3/CD4) $(n=26)$ e Tc (CD3/CD8) $(n=26)$, da relação entre linfócitos "naïve" e de memória (CD45RA/CD45RO) $(n=24)$ e da relação entre linfócitos efetores e células reguladoras (CD4/CD25) $(n=23)$ medidos em sangue periférico.

Figura 10B. Exemplo representativo da análise de fenotipagem por citometria de fluxo de células mononucleares de um paciente no préoperatório e seis meses após a cirurgia. a) Compensação e gating de linfócitos segundo análise de tamanho (FSC) e granulosidade (SSC), utilizados para a aquisição dos dados que foram expressos em porcentagem. b, c e d) controle isotípico. e) células CD3/CD4. f)

células CD3/CD8. g) células CD4/CD25. h) células CD45RA/CD45RO

Figura 11A. Expressão em "dot plot" dos marcadores de superfície de outras populações celulares avaliados por citometria de fluxo no pré-operatório e seis meses após cirurgia. Os dados são representativos da porcentagem da população de células NK (CD56) $(n=22)$ e de linfócitos B (CD19/CD45) $(n=25)$ e de ativação precoce de linfócito $B(C D 19 / C D 69)(n=24)$..

Figura 11B. Exemplo representativo da análise de fenotipagem por citometria de fluxo de células mononucleares de um paciente no préoperatório e seis meses após a cirurgia. Compensação e gating como na figura 10B. a) células CD56. b) células CD19/CD45. c) células CD19/CD69. 
Figura 12A. Expressão em "dot plot" dos marcadores de superfície de ativação avaliados por citometria de fluxo no pré-operatório e seis meses após cirurgia. Os dados são representativos da porcentagem da população dos marcadores de linfócitos T ativados (CD4/CD95 e CD8/CD95) ( $n=24$ e $n=22$, respectivamente), de ativação precoce de linfócito $B(C D 45 / C D 69) \quad(n=23)$ e marcador de linfócito naïve (CD3/CD45RA) ( $n=17)$

Figura 12B. Exemplo representativo da análise de fenotipagem por citometria de fluxo de células mononucleares de um paciente no préoperatório e seis meses após a cirurgia. Compensação e gating como na figura 10B. a) células CD4/CD95. b) células CD8/CD95. c) células CD45/CD69. d) células CD3/CD45RA.

Figura 13. A atividade citotóxica das células NK dos pacientes $(n=28)$ no pré-operatório e seis meses após a cirurgia. 
Moulin de Moraes, C. M. Avaliação de aspectos da resposta imune de pacientes com obesidade grau III após cirurgia bariátrica [tese].

São Paulo: Faculdade de Medicina, Universidade de São Paulo; 2008.

Embora a obesidade esteja associada à disfunção imune, com incidência aumentada de infecções e alguns tipos de cânceres, há poucos estudos que avaliaram parâmetros imunológicos em pacientes obesos graves. Além disso, há um número limitado de trabalhos analisando o efeito da perda de peso sobre parâmetros imunológicos na obesidade grave. Desta forma, o objetivo do presente trabalho foi avaliar a influência da perda de peso de pacientes com obesidade grau III submetidos à cirurgia de derivação gastrojejunal em $\mathrm{Y}$ de Roux (DGJYR) em parâmetros imunológicos. A produção de citocinas associadas com a resposta imune adquirida (IL-2, IL4, IL-10 e IFN- $\gamma$ ) e inata (TNF- $\alpha$ e IL-6) por células mononucleares de sangue periférico (PBMC), o perfil das populações de linfócitos e a atividade citotóxica de células natural killer (NK), além de citocinas associadas a sua função e desenvolvimento (IL-12 e IL-18), foram avaliados em vinte e oito pacientes não diabéticos, sedentários, com obesidade grau III (20 mulheres e 8 homens, com média de idade de 39,9 \pm 10,9 anos e IMC de 49,5 \pm 7,1 $\mathrm{kg} / \mathrm{m}^{2}$ ) no pré-operatório e 6 meses após a cirurgia. As PBMC foram estimuladas com o mitógeno fitohemaglutinina (PHA) e as citocinas produzidas foram quantificadas por ELISA. O perfil das populações de linfócitos foi avaliado por citometria de fluxo. A citotoxicidade mediada por células NK foi determinada pelo ensaio de liberação de LDH por células alvo K562. A perda de peso foi de $35,3 \pm 4,5 \mathrm{~kg}$, com uma significativa redução no IMC seis meses após a cirurgia $\left(-12,9 \pm 0,9 \mathrm{~kg} / \mathrm{m}^{2}, \mathrm{p}<0,001\right)$. Nenhuma das populações de linfócitos analisadas apresentou modificação no $6^{\circ}$ mês após a cirurgia. Observou-se aumento significativo da proliferação de linfócitos seis meses após a cirurgia $(p=0,0026)$. Houve aumento pósoperatório nas concentrações de IFN- $\gamma$, IL-12 e IL-18 produzidas por PBMC após estímulo com PHA, enquanto a IL-2 apresentou uma tendência ao aumento $(p=0,07)$. As demais citocinas não apresentaram variação significativa. A atividade citotóxica das células NK aumentou seis meses após a cirurgia $[17,1 \pm 14,7 \%$ no pré vs $51,8 \pm 11,3 \% 6$ meses pósoperatório, na proporção 40:1 (célula NK:célula alvo); $p<0,001$ ], mostrando recuperação quando se compara aos valores obtidos em indivíduos controle, pareados por idade e sexo, de peso normal [proporção 40:1 (célula NK:célula alvo) de 45,4 $\pm 7,8 \%$ ]. Houve aumento de atividade citotóxica em todos os pontos da curva no pós-operatório em cerca de $79 \%$ da amostra (22 pacientes). Os resultados obtidos demonstram que a perda de peso induzida por DGJYR aumenta a produção de algumas citocinas relacionadas com a função das células NK e melhora a sua atividade citotóxica. As alterações na função de células NK e do nível de citocinas envolvidas com a atividade destas células podem explicar a propensão ao desenvolvimento de infecções e cânceres associados com a obesidade. Os dados obtidos neste estudo sugerem que a cirurgia bariátrica pode ter impacto positivo sobre estes fatores.

Descritores: obesidade, cirurgia bariátrica, imunidade, células natural killer 
Moulin de Moraes, C. M. Evaluation of aspects of immune response of patients with grade III obesity after bariatric surgery [thesis].

São Paulo: "Faculdade de Medicina, Universidade de São Paulo"; 2008.

Although obesity is related to immune dysfunction, with a higher incidence of infections and some types of cancer, few studies have evaluated immunological parameters in severely obese patients. Moreover, a limited set of studies have analyzed the effect of weight loss in immunological parameters in severely obese patients. Thus, the objective of this thesis was to evaluate the influence of weight loss induced by Roux en-Y gastric bypass in patients with grade III obesity in immunological parameters. The production of cytokines associated with acquired (IL-2, IL-4, IL-10 and IFN- $\gamma$ ) and innate (TNF- $\alpha$ e IL-6) immune responses from peripheral blood mononuclear cells (PBMCs), the profile of lymphocytes populations and the cytotoxic activity of natural killer cells (NK), besides cytokines related with NK cell cytotoxic function and development (IL-12 e IL-18), were analyzed in 28 non-diabetic and sedentary patients with grade III obesity (20 women and 8 men, $39,9 \pm 10,9$ years and BMI 49,5 $\pm 7,1 \mathrm{~kg} / \mathrm{m}^{2}$ ) before and 6 months after RYGB. PBMCs were stimulated with the mitogen phytohemagglutinin (PHA) and cytokines were measure by ELISA. The profile of lymphocytes populations was evaluated by flow cytometry. NK cell cytotoxicity was determined by the lactate dehydrogenase release assay from K562 lysed target cells. The weight loss 6 months after surgery was $35.3 \pm 4.5 \mathrm{~kg}$ and there was a significant post-surgical decrease in $\mathrm{BMI}$ at this point $(-12.9 \pm 0.9$ $\left.\mathrm{kg} / \mathrm{m}^{2}, \mathrm{p}<0.001\right)$. No significant differences were found in the lymphocytes populations after surgery. It was observed a significant increase in the lymphocytes proliferation six months after surgery $(p=0.0026)$. There was also a post-surgical increase in the production of IFN- $\gamma$, IL-12 e IL-18 from PBMC stimulated with PHA, while there was a trend towards the increase of the IL-2 production $(p=0.07)$. The other cytokines analyzed were not altered. Cytotoxic activity of NK cells was significantly enhanced 6 months after RYGB $[17.1 \pm 14.7 \%$ before RYGB vs $51.8 \pm 11.3 \%$ at 6 months after, at effector to target cell (NK cell:K562 cell) ratio 40:1; p<0.001], and it was in the same range when compared to data obtained from controls with normal BMI matched for age and gender $(45,4 \pm 7,8 \%$ at NK cell:K562 cell ratio 40:1). There was a significant post-surgical improvement in all points of the cytotoxic activity curve in almost $79 \%$ of the sample (22 patients). In conclusion, the data obtained show that the weight loss induced by RYGB increases the production of cytokines related with NK cell cytotoxic function and improves its activity. The impairment in NK cells cytotoxic activity and cytokines observed in patients with severe obesity may explain their propensity to develop infections and cancer. Our data suggests that the weight loss induced by bariatric surgery can positively impact these factors.

Descriptors: obesity, bariatric surgery, immunity, natural killer cells. 
1. INTRODUÇÃO 
A obesidade é uma condição complexa e multifatorial caracterizada por excesso de gordura corporal ${ }^{1}$. Deve ser considerada uma doença crônica, requerendo, portanto, tratamento e seguimento contínuos.

A obesidade está emergindo rapidamente como epidemia global. Dados do "National Health and Nutrition Examination Survey" (NHANES) de 20032004 demonstram progressão da prevalência de sobrepeso e obesidade na população americana ${ }^{2}$. No Brasil, estudos epidemiológicos mostram que a evolução da obesidade também é ascendente ${ }^{3,4}$, estando $40 \%$ da população adulta com excesso de peso ${ }^{5}$. Quanto a obesidade grau III ou mórbida (IMC $\geq$ $40 \mathrm{~kg} / \mathrm{m}^{2}$ ), sabe-se que sua prevalência nos Estados Unidos é de $2,8 \%$ em homens e $6,9 \%$ em mulheres ${ }^{2}$. Estes dados ainda não estão bem definidos na população brasileira, porém estima-se que $3 \%$ dos brasileiros sejam obesos mórbidos ${ }^{6}$.

A alta prevalência de excesso de peso no mundo provoca grande impacto na saúde pública, por estar associado a inúmeras comorbidades, como doenças cardiovasculares, diabetes mellitus, dislipidemia, colelitíase, osteoartrite, apnéia do sono, distúrbios psiquiátricos e certos tipos de câncer ${ }^{7}$. Além disto, a obesidade tem sido relacionada à disfunção imune, como discutiremos a seguir. Nos Estados Unidos, a morbidade relacionada à obesidade é responsável por $5,7 \%$ dos gastos em saúde, sendo os gastos per capita de um adulto com obesidade grau III 47\% maiores que um obeso grau $\mathrm{I}^{8,9}$. Além disto, cerca de mais 100.000 mortes por ano são atribuídas a esta doença crônica ${ }^{10}$. A perda de peso é rotineiramente recomendada para 
indivíduos com excesso de peso, a fim de reverter ou prevenir estas conseqüências adversas relacionadas à obesidade.

\section{1- Visão geral do sistema imune}

Para o entendimento deste trabalho, consideramos importante rever aspectos básicos do sistema imune. A resposta imune é composta por dois braços interligados: a imunidade inata e adquirida ou adaptativa. Ambas as respostas dependem da atividade dos leucócitos, os quais derivam de precursores na medula óssea. Um esquema geral do sistema hematopoiético está mostrado na figura 1. Uma célula-tronco hematopoiética pluripontente dá origem a linhagens mielóides, que participam das respostas imunes inatas e adquiridas, e a linhagens linfóides, responsáveis pela imunidade adquirida. Além de originar linfócitos $T$ e $B$, o progenitor linfóide também origina a célula "natural killer" (NK), que é um tipo distinto de linfócito que, por não ter memória, nem especificidade para antígenos, é considerado como elemento da imunidade inata. Neutrófilos, eosinófilos e basófilos, conhecidos como granulócitos, atuam como células efetoras em sítios de infecção e inflamação ${ }^{11}$. Macrófagos, que correspondem a forma madura dos monócitos, completam sua diferenciação nos tecidos, onde atuam como células efetoras de primeira linha na defesa do organismo e no início da inflamação. Células dendríticas e macrófagos fagocitam bactérias e secretam substâncias que recrutam neutrófilos da circulação sanguínea. Células 
dendríticas adentram os tecidos como fagócitos imaturos, onde se especializam na ingestão de antígenos, e posteriormente migram para tecidos linfóides, atuando como células apresentadoras de antígenos $(\mathrm{CAA})^{12}$. Além das células descritas, existem os mastócitos, cujos precursores não estão bem definidos, que também completam sua maturação nos tecidos. Os mastócitos têm como principais papéis a defesa contra parasitas e estão envolvidos na indução de reações alérgicas, além de serem capazes de secretar quimiocinas que recrutam eosinófilos e basófilos, os quais exercem função similar e complementar a sua ${ }^{13}$. As células derivadas do progenitor mielóide, juntamente com as barreiras físicas, como pele e mucosas, células NK, sistema complemento e outras substâncias antimicrobianas, como lisozimas, proteína $C$ reativa $(P C R)$ e mediadores inflamatórios, são os componentes da resposta imune inata ${ }^{14}$.

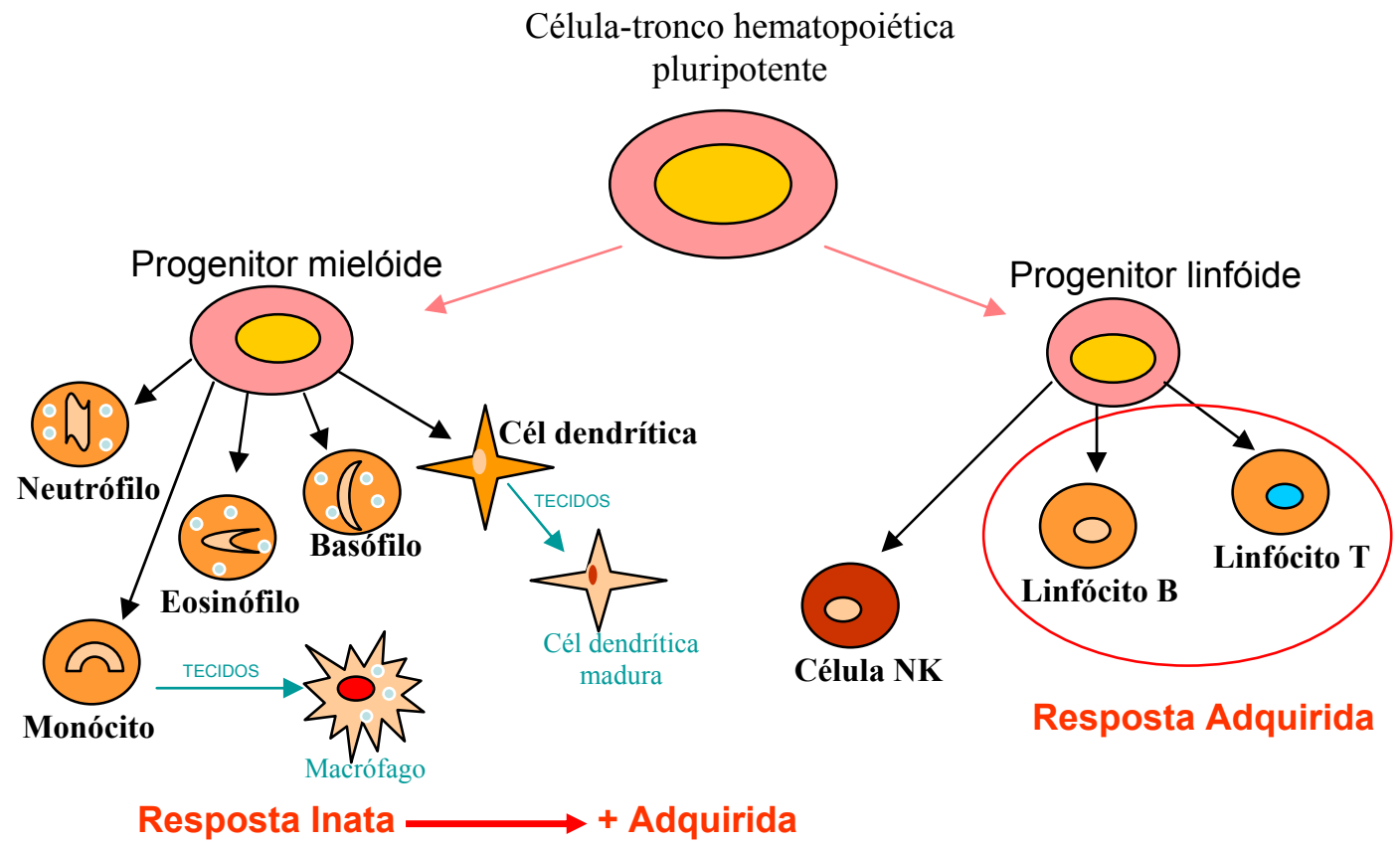

Figura 1. Principais células envolvidas nas respostas imunes. Uma célula-tronco hematopoiética pluripontente dá origem aos progenitores mielóide e linfóide. As células derivadas do progenitor mielóide, que são neutrófilos, eosinófilos, basófilos, monócitos e 
células dendríticas participam da resposta imune inata e são fundamentais para estímulo da resposta imune adquirida. Monócitos e células dendríticas migram para os tecidos, onde se diferenciam, respectivamente, em macrófagos e células dendríticas maduras, que são células especializadas na fagocitose e na apresentação de antígenos aos linfócitos. Já o progenitor linfóide origina os linfócitos $\mathrm{T}$ e $\mathrm{B}$, responsáveis pela imunidade adquirida, além de originar a célula NK, que é um tipo distinto de linfócito que, por não ter memória, nem especificidade para antígenos, é considerado como elemento da resposta inata e que exerce efeito imunoregulatório, influenciando de forma importante a resposta adquirida.

A maturação das células da linhagem mielóide e dos linfócitos B ocorre na própria medula óssea, porém os precursores dos linfócitos T migram para o timo para concluírem sua maturação. A medula óssea e o timo são considerados órgãos linfóides centrais, locais onde os linfócitos são gerados. Uma vez que os linfócitos tenham completado sua maturação, eles entram na corrente sanguínea, migrando para os órgãos linfóides periféricos, onde as respostas imunes adaptativas são iniciadas e onde os linfócitos são mantidos $^{12}$.

A imunidade inata constitui a primeira linha de defesa do organismo. As células que compõem a imunidade inata têm receptores pré-formados, o que faz com que este braço da resposta imune seja de ação rápida, porém seja desprovido de memória e tenha baixa especificidade ${ }^{11}$. Como há um período de cerca de 4-7 dias para que resposta adquirida inicial tenha efeito, a resposta inata tem papel crítico no controle da infecção neste período ${ }^{12}$. Os receptores imunes inatos, que incluem os receptores toll-like, reconhecem um número limitado de moléculas, algumas das quais presentes em vários agentes infecciosos, como lipopolissacarídeos e peptideoglicanos ${ }^{15}$. reconhecimento destas moléculas pelos receptores presentes nas células imunes inatas resulta na ativação de vias sinalizadoras intra-celulares que culminam na produção de citocinas inflamatórias e interferons, alertando o 
organismo para a presença da infecção ou agente não-próprio ${ }^{16}$. Portanto, as células da resposta imune inata exercem um papel crucial na iniciação e, subseqüente, direcionamento das respostas adaptativas e participam na remoção de patógenos, alvos dos linfócitos ${ }^{12}$.

Por sua vez, a imunidade adquirida é caracterizada pela especificidade e memória, como resultado de exposição prévia a microrganismos invasores ou determinantes antigênicos reconhecidos como não próprios ${ }^{11}$. A memória imunológica confere à resposta imune adaptativa a capacidade de responder mais efetivamente a um dado antígeno a cada exposição, promovendo proteção aumentada contra re-infecção. A imunidade adquirida é baseada na seleção e expansão clonal de linfócitos com receptores antígenoespecífico $^{14}$. Cada progenitor linfóide dá origem a um grande número de linfócitos, cada um com diferente especificidade. Os linfócitos com receptores que ligam antígenos próprios com alta afinidade são eliminados antes de se tornarem funcionais, levando à tolerância a tais antígenos próprios, num processo conhecido como seleção negativa ou tolerância central, já que esta forma de tolerância é induzida no órgão linfóide central ${ }^{11}$. Quando um antígeno não próprio interage com o receptor no linfócito "naïve" (inexperiente), esta célula é ativada e começa a se dividir, produzindo vários progenitores idênticos, que são os clones, todos com receptores idênticos, que se ligam ao mesmo antígeno que estimulou a ativação e expansão clonal. A especificidade antigênica é mantida até a proliferação e diferenciação destas células em efetoras. Uma vez que o antígeno tenha sido 
eliminado pelas células efetoras, a resposta imune cessa, embora alguns linfócitos sejam preservados para mediar a memória imunológica ${ }^{12}$.

Os antígenos são fagocitados nos sítios de infecção por células dendríticas e macrófagos, os quais migram para os órgãos linfóides secundários, onde funcionam como CAA. Os órgãos linfóides secundários são tecidos anatomicamente distintos, formando agregados de tecido linfóide, dentro dos quais ocorre o reconhecimento do antígeno pelo linfócito, iniciando a resposta imune adaptativa. Estes órgãos linfóides especializados incluem linfonodos, baço e tecidos linfóides associados à mucosa. Linfonodos estrategicamente localizados, por exemplo, formam uma rede de proteção na detecção de antígenos intersticiais, enquanto o baço é importante na deteç̧ão e proteção contra patógenos em corrente sanguínea. Por sua vez, os tecidos linfóides associados à mucosa exercem crítica proteção em superfícies mucosas, como as dos pulmões, trato gastrointestinal e trato reprodutivo, por coletar antígenos diretamente destes locais ${ }^{17}$. Os tecidos linfóides periféricos fornecem sinais sustentados aos linfócitos que não encontraram seus antígenos específicos, contribuindo para que estes linfócitos sobrevivam e recirculem até que encontrem seu antígeno específico ou sofram apoptose. Isto é importante na manutenção do número correto de linfócitos T e B em circulação e garante que somente aqueles linfócitos com o potencial para responder a antígenos estranhos sejam mantidos $^{12}$.

Os componentes da imunidade antígeno-específica incluem a resposta humoral, dependente dos linfócitos $B$, e a resposta mediada por células, que 
depende de linfócitos T e seus produtos, as citocinas. Os dois componentes da resposta adquirida atuam em conjunto, promovendo a defesa integrada contra infecções, dano celular ou mecanismos patogênicos. Após encontrarem com o antígeno, os linfócitos B se diferenciam em plasmócitos, células que sintetizam e liberam anticorpos específicos, enquanto os linfócitos $T$ se diferenciam em células efetoras com uma variedade de funções. Os anticorpos produzidos pertencem a diferentes classes de imunoglobulinas dependendo do tipo de estímulo e do sítio anatômico dos linfócitos envolvidos ${ }^{18}$. Os anticorpos podem proteger contra patógenos, ou seus produtos tóxicos, pela ligação com estes, bloqueando seu acesso a células (neutralização), facilitando seu reconhecimento pelo fagócito (opsonização) e ativando o sistema complemento, o que aumenta a ação bactericida de fagócitos ${ }^{11}$.

Os linfócitos $\mathrm{T}$ podem ser funcionalmente divididos em linfócitos $\mathrm{T}$ auxiliares ["helper" (Th)] e linfócitos T citotóxicos (Tc), dependendo da expressão diferenciada de CD4+ e CD8+, respectivamente. Os linfócitos Th são responsáveis pela maioria das funções efetoras, como estímulo da proliferação de linfócitos e ativação de macrófagos, células NK e linfócitos B, enquanto os linfócitos Tc são mediadores da maioria das atividades citotóxicas contra células infectadas por vírus e tumores ${ }^{12}$. Como os linfócitos $\mathrm{T}$, diferentemente dos linfócitos $\mathrm{B}$, não reconhecem diretamente antígenos naturais, é necessário que estes sejam processados por CAA. As CAA, que incluem, além de macrófagos e células dendríticas nos tecidos, linfócitos B ativados e monócitos no sangue, fagocitam os agentes estranhos, 
quebrando-os em pequenos fragmentos proteicos (peptídeos antigênicos), que são posteriormente apresentados aos linfócitos T em sua membrana, por molécula codificada pelo complexo principal de histocompatibilidade (MHC). Para o desencadeamento da expansão clonal de células $T$ "naïve" e sua diferenciação em células $T$ efetoras, também é necessária a expressão de sinais co-estimulatórios pelas $C A A^{19}$. Em função da natureza do antígeno e das condições de ativação, uma proporção dos linfócitos Th efetores se diferencia em Th1 ou Th2, com padrões de citocinas específicos e funções definidas $^{12}$

As células do tipo Th1 estão envolvidas nas reações celulares inflamatórias e nas reações de hipersensibilidade tardia. As principais citocinas secretadas por estas células são interleucina (IL)-2, interferon (IFN)$\gamma$ e linfotoxina ${ }^{20}$. A IL-2 está envolvida na proliferação de células $T^{12}$. A produção de IL-2 e IFN- $\gamma$ ativa linfócitos Tc, os quais também produzem IFN$\gamma$. A IL-2 contribui para a proliferação e ativação de células NK, enquanto IFN- $\gamma$ estimula a atividade citotóxica destas células, juntamente com IL-12 e IL-18 ${ }^{21}$. O IFN- $\gamma$ também ativa macrófagos, aumentando a fagocitose e amplificando sua capacidade microbicida, e ativa linfócitos B, estimulando sua produção de anticorpos opsonizantes [predominantemente imunoglobulina $(\mathrm{Ig}) \mathrm{G}]$, os quais auxiliam a fagocitose ${ }^{12}$. O IFN- $\gamma$ induz enzimas anti-virais, bloqueando a replicação viral ou levando a eliminação do vírus de células infectadas, sem matá-las ${ }^{22}$. Já a linfotoxina ativa macrófagos, inibe células $B$ e é diretamente citotóxica para algumas células ${ }^{12}$. 
As células do tipo Th2 produzem principalmente as citocinas IL-4, IL-5, IL-10 e IL-13, que estão envolvidas na síntese de IgA, IgM e, principalmente, $\lg \mathrm{E}$ e na ativação de mastócitos, eosinófilos e dos próprios linfócitos Th2 ${ }^{12}$. A IL-4 (principal molécula efetora de Th2) participa da ativação de linfócitos B em células secretoras de anticorpos e favorece o desenvolvimento das células Th2 ${ }^{23}$. Por sua vez, a IL-5 aumenta a produção e a diferenciação de eosinófilos, contribuindo para fases tardias da resposta alérgica, enquanto a IL-10 suprime a ativação de monócitos ${ }^{12,23}$. A IL-10 tem uma potente função anti-inflamatória, ao inibir Th1 e ao suprimir as funções pró-inflamatórias das CAA, por antagonizar a expressão de moléculas co-estimuladoras, a liberação de citocinas pró-inflamatórias e, em geral, a maturação das $C_{A} A^{24}$. Atua, portanto, limitando a resposta inflamatória excessiva, provavelmente evitando doenças relacionadas à inflamação ${ }^{25}$. Já a IL-13, de forma semelhante a IL-4, exerce efeitos sobre linfócitos B e monócitos, estimulando a expressão de $\mathrm{MHC}$ classe II, promovendo a produção de IgE e inibindo a produção de citocinas inflamatórias ${ }^{26}$.

Tanto células Th1 quanto células Th2 podem secretar IL-3, fator de necrose tumoral (TNF)- $\alpha$ e fator estimulador de colônia de granulócitos ${ }^{20}$. A IL-3 favorece a diferenciação de granulócitos, células eritróides e megacariocitóides e induz a proliferação de precursores de linfócitos $B$, além de ser responsável pela ativação de mastócitos em superfícies mucosas ${ }^{27}$. Monócitos e macrófagos também secretam TNF- $\alpha$ e outras interleucinas, como IL-1, IL-6 e IL-12, chamadas em conjunto de citocinas próinflamatórias, pois, entre outras funções, induzem a produção de outras 
citocinas pelos linfócitos $\mathrm{T}^{12}$. O TNF- $\alpha$ estimula a migração de células dendríticas dos tecidos periféricos para os linfonodos e sua maturação em CAA. A IL-1 ativa o endotélio vascular e a destruição tecidual local, aumentando o acesso das células efetoras ao sítio de infecção. A IL-6 estimula a proliferação e maturação dos linfócitos T e B e aumenta fatores estimuladores de colônia de monócitos, macrófagos e granulócitos ${ }^{12}$. A IL-12, também produzida por células dendríticas e, em menor quantidade, por células $B$, exerce papel central na ligação das respostas imunes inatas e adaptativas $^{20,28}$. Esta citocina estimula a proliferação e aumenta a atividade citotóxica das células NK e promove a diferenciação de linfócitos Th "naïve" em Th1, além de ser potente indutora da síntese de IFN- $\gamma^{28}$. A produção de IFN- $\gamma$ induzida por IL-12 estimula a produção da própria IL-12 em macrófagos. Esta amplificação parece ser importante na iniciação ou estabilização da resposta Th1 ${ }^{22}$. A IL-18, secretada por macrófagos e células dendríticas, atua em sinergismo com IL-12 na indução da produção de IFN$\gamma^{29}$. Esta citocina exerce importante papel na modulação da função de células T, dendríticas e NK. Ela aumenta a maturação de células T e células NK, a produção de citocinas e a citotoxicidade destas células $^{29}$. IL-18 tem a capacidade de induzir a polarização Th1 ou Th2, dependendo do contexto imunológico: aumenta as repostas imunes Th1 guiadas por IL-2, mas também pode estimular as repostas imunes Th2, na ausência de IL-12 ${ }^{30}$.

As citocinas avaliadas neste estudo estão destacadas na figura 2. 


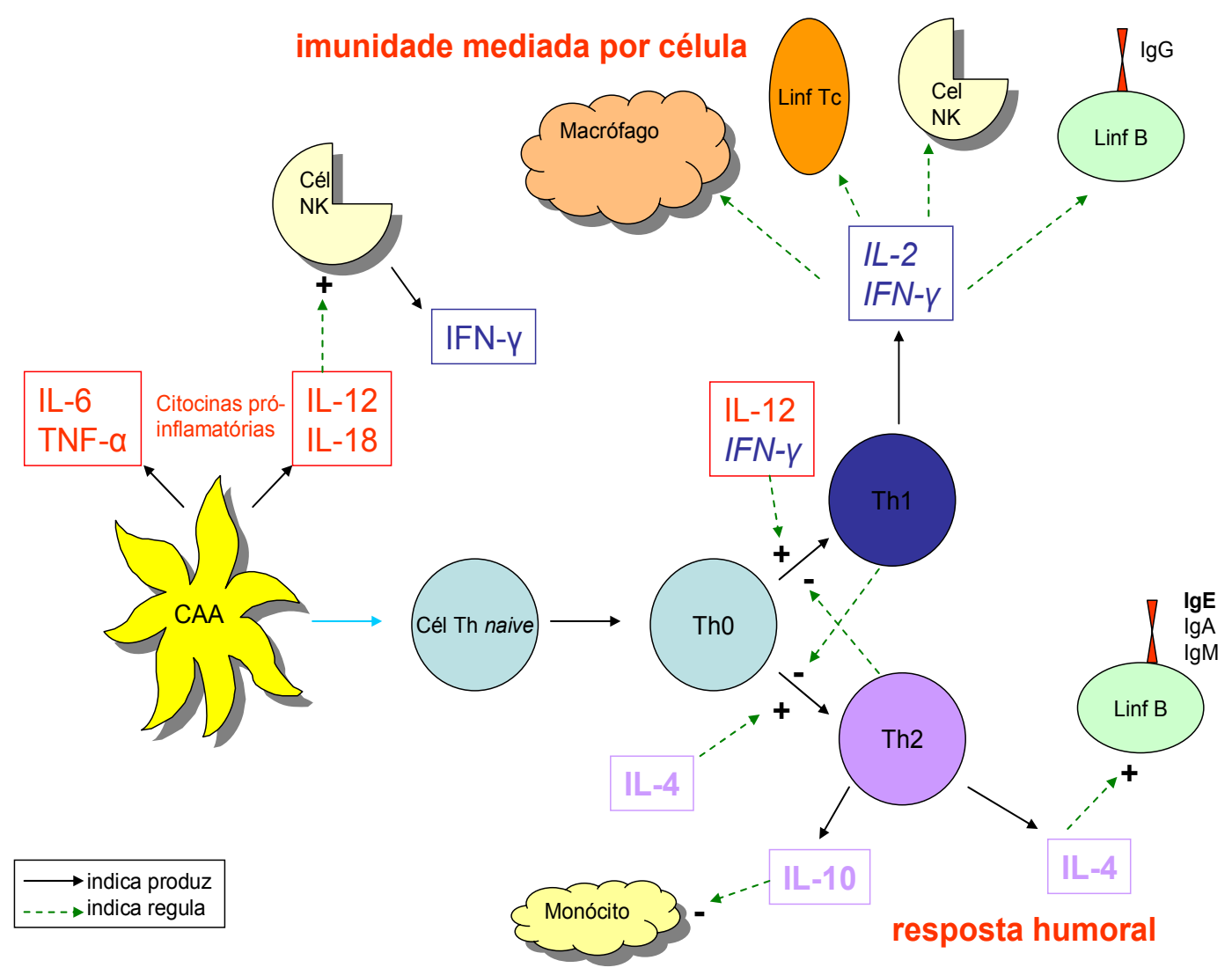

Figura 2. O papel das citocinas na diferenciação e na função efetora de linfócitos $T$ e células NK. Os linfócitos são subdivididos de acordo com o padrão de citocinas que produzem. Após o reconhecimento do antígeno, apresentado pelas CAA, a célula Th naive se diferencia em uma população celular denominada Th0, a qual origina Th1 ou Th2. A diferenciação em Th1 ou Th2 é regulada por citocinas: IL-12 e IFN- $\gamma$ promovem o desenvolvimento de células Th1, enquanto IL-4, o desenvolvimento de células Th2. Células Th1 produzem IL-2 e IFN-y, os quais ativam macrófagos, linfócitos Tc e células NK, além de linfócitos B produtores de anticorpos IgG. Estas células são os principais efetores da imunidade mediada por célula e da hipersensibilidade tardia. Células Th2 promovem a resposta humoral ao produzirem IL-4, o qual estimula a produção de $\lg \mathrm{A}, \lg \mathrm{M}$ e, principalmente, IgE pelos linfócitos B, e IL-10, que junto com IL-4, suprime a imunidade mediada por célula e a inflamação. Citocinas derivadas de Th1, especialmente IFN-y, inibem a diferenciação de células Th2, enquanto citocinas de Th2, especialmente IL-4, inibem a diferenciação de células Th1. As CAA secretam citocinas pró-inflamatórias, como TNF- $\alpha$, IL6 e IL-12, além de IL-18. IL-12 e IL-18 atuam sinergicamente na indução da produção de IFN-y pelas células NK e no aumento da atividade citotóxica destas células. Modificada de Calder PC et al. ${ }^{18}$.

A predominância na resposta imune adaptativa do componente celular ou humoral é determinada pela diferenciação e ativação de células Th1 ou Th2, respectivamente. O fator que determina em que subpopulação a célula 
Th "naïve" vai se diferenciar não é completamente entendido, mas esta diferenciação ocorre cedo na resposta imune. As infecções causadas por patógenos intracelulares, como por bactérias e vírus, tendem a induzir atividade Th1, o que leva à produção de citocinas que estimulam a atividade de células capazes de destruir tais patógenos, como macrófagos, células Tc e células NK, além de $\lg ^{18}$. Já exposição a patógenos extracelulares, como em infestações helmínticas, tende a induzir a diferenciação de linfócitos Th para o padrão Th2, a qual leva a respostas que contribuem para a eliminação de tais patógenos, como a produção de $\lg ^{18}$. As células dendríticas geralmente induzem respostas Th1, enquanto as células B induzem respostas Th2. Baixas doses de antígenos induzem resposta Th1. Por outro lado, altas doses dos mesmos, onde a CAA for célula B ou dendrítica, aumentam Th2. A polarização das respostas em Th1 ou Th2 não somente tem diferentes papéis na proteção, mas também pode promover reações imunopatológicas. Respostas Th1 parecem estar envolvidas em doenças auto-imunes, enquanto respostas Th2 são responsáveis por deflagrar distúrbios alérgicos e atopias ${ }^{20}$.

A função principal das células NK é a indução de morte por citotoxicidade ou por apoptose em células que apresentem uma diminuição das moléculas de MHC classe I ou que expressam determinadas substâncias, notadamente lipídeos e polissacarídeos, associados à molécula de CD1, que é uma molécula não clássica do MHC classe $\mathrm{I}^{31}$. Ambas as circunstâncias estão associadas à infecção por alguns tipos virais, sobretudo os da família dos herpesvírus, a alguns tipos de tumores ou a certas 
infecções bacterianas. Apesar de pertencer à linhagem linfóide, a célula NK é considerada como elemento da imunidade natural, por não atuar com especificidade e nem desenvolver memória, características dos outros linfócitos $^{31}$. Possuem, porém, a capacidade de expansão clonal, como os outros linfócitos ${ }^{32}$. Estas células também produzem IFN- $\gamma$ e exercem efeito imunoregulatório por interação com células dendríticas ${ }^{12}$. As células NK e os interferons têm papel essencial no combate inicial das infecções virais, antes da atuação da imunidade adquirida, e parecem ser responsáveis pela rápida recuperação no caso de viroses de curta duração, como resfriados ${ }^{33}$. Trabalhos mostram que a citotoxicidade de células NK parece estar inversamente associada com o risco e gravidade de infecções ${ }^{34,35}$. Ogata et al. ${ }^{36}$ concluíram que a baixa atividade citotóxica de células NK estava associada com desenvolvimento de infecções e mortes por infecções em uma coorte de idosos. Outra função relevante das células NK é a proteção contra tumores. As células NK podem eliminar células que se tornam malignas antes delas causarem um tumor ${ }^{31}$. As células NK humanas são capazes de destruir células cancerígenas de várias origens, como melanoma, sarcoma, carcinoma ovariano e colônico e células leucêmicas "in vitro”37. A relevância clínica destes achados é confirmada por alguns estudos. Em um estudo prospectivo de 11 anos, que incluiu mais de 3.600 pessoas, menor atividade citotóxica de células NK foi associada com incidência aumentada de cânceres ${ }^{38}$. Pacientes com síndrome de Chediak-Higashi, uma doença autossômica recessiva caracterizada por anormalidade da função citotóxica de célula NK, têm um risco 200 vezes maior de 
desenvolvimento de tumores malignos ${ }^{39}$. Além disto, a redução da função de células NK em pacientes com câncer está relacionada com pior prognóstico, maior risco de desenvolvimento de metástases regionais e à distância e aumento da mortalidade ${ }^{39}$.

\section{2- Relação entre função imune e obesidade}

Como já foi dito, a obesidade tem sido relacionada não só a uma grande variedade de comorbidades endócrinas e metabólicas, mas também à disfunção imune ${ }^{40}$. A obesidade influencia a resposta imune inata e adaptativa, sendo observada uma tendência à deterioração da imunidade com o avanço do grau de obesidade $\mathrm{o}^{40,41}$.

Animais com obesidade induzida por dieta, considerados modelos experimentais comparáveis à obesidade em humanos, exibem alterações de parâmetros imunológicos. Lamas et al. $^{42,43}$ observaram, em ratos com sobrepeso, redução de linfócitos Th, menor resposta proliferativa de esplenócitos em resposta a mitógenos e tendência à menor atividade citotóxica de células NK. Além disto, foi observado menor produção estimulada de IL-2 ${ }^{42}$. Ratos com obesidade induzida por dieta também apresentam alteração na resposta de hipersensibilidade de contato ${ }^{44}$.

Estudos revelam que a incidência e gravidade de certas infecções são maiores em pacientes obesos que em não obesos ${ }^{45-48}$. Observou-se também risco aumentado de atraso na cicatrização de feridas em obesos após 
procedimentos cirúrgicos ${ }^{48}$. Weber et al $^{49}$ relataram menor produção de anticorpos após vacinação para hepatite B em pacientes obesos.

Maior incidência de certos tipos de câncer em pacientes obesos também tem sido associada com alterações da resposta imune ${ }^{50}$. A obesidade está relacionada a uma condição de inflamação crônica, caracterizada pela produção anormal de citocinas pró-inflamatórias com efeitos locais ou sistêmicos, como TNF- $\alpha$ e IL-6, respectivamente, que podem contribuir para 0 desenvolvimento de cânceres ${ }^{51}$. Embora a inflamação local limitada possa ser fundamental para a iniciação das respostas imunes e, portanto, protetora para o organismo, a inflamação excessiva pode promover a progressão tumoral ${ }^{52}$. A obesidade, ao levar ao aumento de células inflamatórias e citocinas, causa uma superprodução crônica de espécies reativas de oxigênio, as quais podem induzir alterações mutagênicas e danificar proteínas reparadoras do DNA, contribuindo para o desenvolvimento do câncer ${ }^{53}$. Além disto, as citocinas pró-inflamatórias podem exacerbar a resistência insulínica. A hiperinsulinemia aumenta as concentrações de IGF-1 plasmático, o qual, juntamente com a insulina, pode promover o desenvolvimento tumoral por inibição de apoptose e por estímulo de proliferação celular, já que ambas são moléculas anabólicas ${ }^{54}$.

Dados na literatura apontam diferenças na resposta imune entre indivíduos obesos e não obesos. A obesidade está relacionada com maior contagem de leucócitos ${ }^{55-57}$, neutrófilos e monócitos ${ }^{56,57}$ e menor proliferação de linfócitos induzida por mitógeno ${ }^{58-60}$. Chandra e Kutty ${ }^{60}$ encontraram, além da alteração da proliferação de linfócitos estimulada por mitógenos, prejuízo 
nas respostas cutâneas de hipersensibilidade tardia e na capacidade bactericida de neutrófilos em crianças e adolescentes obesos.

Poucos estudos enfocaram a avaliação de variáveis específicas da resposta imune em obesos grau III. Trabalhos da década de 80 descreveram, em pacientes com obesidade grave, menor taxa de maturação de monócitos em macrófagos ${ }^{61}$ e menor capacidade bactericida de polimorfonucleares ${ }^{62}$, além de aumento na reatividade cutânea após inoculação de estreptoquinase/estreptodornase e candidina ${ }^{63}$. Estudos recentes observaram diferenças em alguns marcadores de superfície de monócitos, neutrófilos e linfócitos entre obesos mórbidos e controles de peso normal ${ }^{64,65}$.

É importante ressaltar que, além de ser limitado o número de estudos que avaliaram índices específicos de função imunológica em pacientes obesos, em particular pacientes com obesidade grave, estes estudos incluíram somente pequeno número de pacientes e poucos testes imunológicos.

\section{3- Tecido adiposo como órgão pró-inflamatório}

O tecido adiposo é um órgão endócrino dinâmico que secreta vários fatores, como IL-6, TNF- $\alpha$, proteínas relacionadas ao complemento e leptina, que reconhecidamente contribuem para a inflamação vascular e sistêmica e que estão aumentados na obesidade ${ }^{66,67}$. Alguns estudos sugerem que préadipócitos poderiam funcionar como células semelhantes a macrófagos, 
aumentando a possibilidade de uma participação direta do tecido adiposo em processos inflamatórios $^{68}$. Além disto, estima-se que em magros, os macrófagos correspondam a $10 \%$ da celularidade do tecido adiposo, enquanto, em obesos, este número aumente para $40-50 \%{ }^{69}$. Citocinas inflamatórias, como IL-6 e TNF-a, parecem ser produzidas principalmente por estes macrófagos contidos no tecido adiposo ${ }^{69}$.

A liberação de IL-6, além de ativar células do sistema imune e induzir a síntese hepática de proteínas de fase aguda, aumenta a atividade do eixo hipotálamo-hipófise-adrenal, o qual participa como mediador de respostas metabólicas e imunes ${ }^{70}$. A IL-6 reduz a atividade da lipoproteína lipase, favorecendo a captação lipídica por macrófagos, contribuindo para a progressão da placa de ateroma ${ }^{70}$. Pode, portanto, ser considerada mediador inflamatório e aterosclerótico ${ }^{66}$. Estima-se que um terço dos níveis circulantes de IL-6 seja originado do tecido adiposo ${ }^{66}$. Diante da substancial contribuição do tecido adiposo como fonte de IL-6 e do fato da IL-6 representar o maior regulador da resposta de fase aguda hepática, se considera que a obesidade se assemelha a um estado inflamatório de baixo grau ${ }^{70}$. O TNF- $\alpha$ é também um fator implicado na ativação da resposta imune ${ }^{12}$. É considerado importante mediador da resistência insulínica na obesidade, estando, desta forma, envolvido na patogênese do diabetes mellitus e da hiperlipidemia ${ }^{71}$.

Adipócitos sintetizam e secretam pelo menos três proteínas constituintes do sistema complemento: complemento $C 3$, fator $B^{58}$ e fator $D$ ou adipsina ${ }^{66,72}$. Estes fatores são componentes da via alternativa do complemento, a qual pode ser ativada sem um complexo antígeno-anticorpo. 
A ativação destes fatores gera C3a, o qual, após a remoção da molécula de arginina carboxi terminal, origina a proteína estimuladora da acilação (ASP), um estimulador do estoque de triglicerídeos pelo tecido adiposo ${ }^{73}$. Desta forma, a regulação da ASP pode ter importantes conseqüências metabólicas e estar associada com obesidade e doença cardiovascular ${ }^{73}$.

A leptina é o fator produzido pelo adipócito mais bem estudado. Seus níveis plasmáticos se correlacionam com o total de massa de gordura corporal e são alterados por condições como jejum e superalimentação ${ }^{74}$. Devido a similaridades estruturais da leptina e seu receptor com outras citocinas, sugere-se que seja classificada como uma citocina ${ }^{75}$. Seu receptor funcional está expresso não somente no hipotálamo, onde regula a homeostase energética e funções neuroendócrinas ${ }^{76}$, mas também em todos os tipos de células da imunidade inata e adaptativa ${ }^{77}$. A leptina influencia inúmeras respostas relacionadas à imunidade, ao ser capaz de estimular o desenvolvimento de células mielóides ${ }^{78}$, ativar monócitos ${ }^{79}$ e macrófagos ${ }^{80,81}$, ter efeito imunomodulador sobre células dendríticas ${ }^{82}$ e células $N^{83}$ e influenciar a proliferação e produção de citocinas pelos linfócitos T, levando a resposta imune ao fenótipo de $\mathrm{Th} 1^{84,85}$. Chan et al. ${ }^{86}$ mostraram que a remoção completa de leptina no soro por anticorpo anti-leptina humana suprimiu a resposta proliferativa de linfócitos T "in vitro", a qual foi restaurada após a adição de leptina recombinante.

Estudos em ratos com deficiência e com defeitos no receptor de leptina sugerem um papel para a leptina na regulação da função imune. Estes animais exibem redução da função fagocítica de macrófagos ${ }^{87}$ e de 
respostas de linfócito $\mathrm{T}^{88,89}$, atrofia de órgãos linfóides ${ }^{89,90}$ e alteração da funcão de células dendríticas ${ }^{91}$, sendo estas alterações revertidas com a administração de leptina em casos de deficiência ${ }^{80,90,91}$. A hipoleptinemia também está associada com aumento da toxicidade induzida por lipopolissacarídeos $^{92}$ e por TNF- $\alpha^{93}$. De forma semelhante, humanos com obesidade causada pela rara deficiência congênita de leptina parecem ter uma maior incidência de morte por infecção na infância ${ }^{94}$. A administração de leptina humana recombinante a duas crianças com esta deficiência restaurou a resposta proliferativa e o perfil de liberação de citocinas de seus linfócitos ${ }^{95}$. Por outro lado, deficiência de leptina pode melhorar doenças, cuja patogênese é mediada por Th1, como é o caso da doença inflamatória intestinal $^{75}$.

\section{4- Efeitos dos nutrientes sobre o sistema imune}

Nutrição é um determinante crítico das respostas imunes ${ }^{96}$. Tanto o estado nutricional como nutrientes específicos podem afetar o sistema imune diretamente (ex: desencadeando a ativação de células imunes ou alterando as interações entre células imunes) ou indiretamente (ex: alterando os substratos para a síntese de DNA, o metabolismo energético e a integridade fisiológica das células ou alterando sinais e hormônios) ${ }^{97}$.

Desnutrição protéica está associada com prejuízo da imunidade mediada por células e redução da função fagocítica, do sistema 
complemento, da concentração de $\lg A$ e da produção de citocinas $^{96}$. Deficiência de nutrientes simples também resulta em alteração das respostas imunes, o que é observado até quando o estado de deficiência é relativamente leve. Dos micronutrientes, zinco, selênio, ferro, cobre, vitaminas $A, C$, E e B-6 e ácido fólico têm importante influência no sistema imune $e^{96,98}$.

Por outro lado, a ingestão excessiva de nutrientes também pode alterar a resposta imune direta ou indiretamente por afetar o estado metabólico e endócrino $^{99}$. A gordura da dieta é considerada um modulador importante da resposta imune, por, entre outros mecanismos, fornecer precursores para a biosíntese de vários eicosanóides, incluindo prostaglandinas e leucotrienos, e alterar o metabolismo de lipoproteínas ${ }^{100}$. Uma dieta rica em gordura pode prejudicar a função de linfócitos ${ }^{18}$. Um estudo mostrou que dieta rica em gordura saturada prejudica a reatividade de linfócitos T "naïve" e linfócitos T previamente expostos a antígeno ${ }^{101}$. Barone et al. ${ }^{102}$ mostraram que a redução da ingestão percentual de gordura melhorou a atividade citotóxica de células NK. Observou-se que indivíduos obesos geralmente consomem maior quantidade de gordura ${ }^{103}$, o que pode ser um fator contribuinte para a disfunção imune neste grupo. 


\section{5- Efeitos da perda de peso induzida por dieta sobre o sistema imune}

Investigações preliminares sugerem que certos tipos de estratégias para redução de peso produzem alterações na resposta imune. Ratos com sobrepeso induzido por dieta apresentaram aumento dos níveis de linfócito Th, da proliferação de esplenócitos estimulada por mitógenos e da atividade citotóxica das células NK quando submetidos à restrição calórica por um mês ${ }^{43}$. Dieta com restrição calórica é o tratamento para obesidade mais empregado. A imunocompetência durante e após perda de peso induzida por dieta restritiva foi avaliada em alguns estudos, com resultados controversos.

Há estudos que descrevem melhora da função imune após redução de peso. Um trabalho mostrou que, apesar da diminuição da proliferação de linfócitos estimulada por mitógenos após 14 dias de dieta, houve melhora em várias medidas da imunidade após a perda de peso, como aumento da atividade bactericida de monócitos, da atividade citotóxica de células NK, das respostas de testes cutâneos de hipersensibilidade tardia e das concentrações de imunoglobulinas ${ }^{104}$. Por sua vez, Tanaka et al. ${ }^{58,59}$ mostraram que a proliferação de linfócitos estimulada por mitógenos, suprimida em obesos, foi restaurada após perda de peso induzida por dieta com muito baixas calorias (VLCD).

Por outro lado, alguns pesquisadores observaram que a perda de peso está associada com redução da função de certos aspectos do sistema imune. Supressão da quimiotaxia e da capacidade microbicida de neutrófilos foram 
descritas após três meses de VLCD em pacientes que fizeram cetose ${ }^{105}$ Restrição calórica por três meses resultou em diminuição da concentração de IgG, IgA, fator C3 do complemento e do número de células NK circulantes em mulheres com sobrepeso ${ }^{106}$. Supressão da atividade de células NK, sem redução da população de células NK no sangue periférico, ocorreu em mulheres obesas submetidas a oito semanas de dieta de $950 \mathrm{kcal} / \mathrm{dia}^{107}$. Redução da proliferação de linfócitos estimulada por mitógenos foi relatada após seis semanas de $\operatorname{VLCD}^{108}$ e após restrição energética moderada (12001300 kcal) por 12 semanas ${ }^{56}$. Field et al. ${ }^{108}$ observaram também redução da percentagem de linfócitos Th e queda de relação de células CD4+/CD8+ durante VLCD, com recuperação destes valores após a realimentação. Um estudo relatou que respostas de testes cutâneos de hipersensibilidade tardia e de produção de anticorpos após imunização foram reduzidas após um período de 12 semanas de VLCD, 6 semanas de realimentação e 8 semanas de dieta convencional de 1200-1500 kcal. Estes parâmetros permaneceram diminuídos após 10 meses do término deste protocolo ${ }^{99}$. Diferenças nas técnicas dos ensaios empregados, nos tipos de pacientes e nos regimes de perda de peso tornam difícil a interpretação dos estudos existentes. 


\section{6- Perda de peso induzida por cirurgia bariátrica e efeitos potenciais no sistema imune}

O tratamento cirúrgico da obesidade tem se mostrado como a forma mais eficiente para perda de peso e manutenção em longo prazo em obesos mórbidos ${ }^{109}$. Vários procedimentos cirúrgicos estão disponíveis, com sucesso terapêutico variável, conforme a técnica empregada. Estes procedimentos geram perda de peso por dois mecanismos: restrição e má absorção ${ }^{110}$.

Cirurgias de derivação intestinal (jejuno-ileal), que produzem perda de peso por má absorção, foram os procedimentos mais comumente empregados do final dos anos 60 até os anos 80. Por induzirem complicações graves, como alterações hepáticas, enteroartropatia, nefrolitíase, deficiências de vitaminas e minerais, foram substituídas por novas técnicas ${ }^{111}$. Dois estudos relataram melhora na função imune após esta cirurgia. Palmblad $\mathrm{J}$ et al. ${ }^{62}$ demonstraram normalização da função bactericida de polimorfonucleares e aumento da resposta proliferativa de linfócitos. Hallberg D et al. ${ }^{112}$ também demonstraram um aumento nos testes de hipersensibilidade tardia. Por outro lado, há relatos de infecções fúngicas raras após este procedimento ${ }^{113}$. Adami et al. ${ }^{114}$ observaram redução de valores quantitativos dos testes de hipersensibilidade tardia em pacientes submetidos a derivação biliopancreática total, outra técnica predominantemente disabsortiva. 
Procedimentos de restrição gástrica, que promovem perda de peso primariamente por restrição física da ingestão de alimentos e indução da saciedade, substituíram as cirurgias de derivação intestinal como técnicas cirúrgicas de escolha. Gastroplastia vertical com bandagem (GVB) e banda gástrica ajustável (BGA) são exemplos deste tipo de procedimento. Estudos descrevem diminuição dos níveis de polimorfonucleares e linfócitos após perda de peso por BGA ${ }^{115,116}$. Após seis meses de BGA, observou-se queda nos níveis de proteínas de fase aguda ${ }^{115}$. Por sua vez, van Dielen et al. ${ }^{117}$ mostraram que receptores solúveis de TNF e proteínas de fase aguda se mantiveram elevados até seis meses após cirurgias restritivas, evoluindo com queda significativa apenas após um ano de intervenção. Redução dos níveis séricos de IL-3 e TNF- $\alpha$ foi observada seis meses após perda de peso induzida por GVB ${ }^{118}$. Hu et al. ${ }^{119}$ descreveram menores níveis de CD4 e maiores níveis séricos de IL-2 e IL-6 em indivíduos com IMC $\geq 35 \mathrm{~kg} / \mathrm{m}^{2}$ quando comparados a controles e, seis meses após BGA, aumento de CD4 e redução de IL-2 nestes pacientes.

Maiores taxas de sucesso de perda de peso têm sido obtidas com as cirurgias mistas, que consistem na redução da capacidade gástrica associada a uma derivação gastroentérica ${ }^{120}$. A derivação gastrojejunal e reconstrução em Y de Roux (DGJYR) é a cirurgia bariátrica mais comumente empregada, sendo considerada como padrão ouro, já que demonstra os melhores resultados, com menores taxas de complicações ${ }^{110}$. A técnica de Fobi-Capella é a mais utilizada em nosso hospital. Nesta técnica, a restrição é criada pelo pequeno reservatório gástrico $(15-30 \mathrm{~mL})$ e pela redução do 
seu esvaziamento através do emprego de um anel de contenção. Em adição, a técnica fornece um grau pequeno a moderado de má absorção intencional, pela derivação do fundo, corpo gástrico, antro, duodeno e parte variável do jejuno proximal.

Com a limitação na ingestão de alimentos, imposta pela restrição da capacidade gástrica, e exclusão de boa parte do intestino delgado, envolvido na absorção de nutrientes, há o risco de desenvolvimento de deficiências nutricionais, principalmente deficiência de cálcio, ferro, folato e vitamina $\mathrm{B} 12^{121}$. Como alguns micronutrientes são críticos para a manutenção da função imune, alterações imunológicas podem ser esperadas em pacientes submetidos a este procedimento.

A maioria dos estudos que avaliaram o efeito das cirurgias bariátricas sobre o sistema imune teve como enfoque os marcadores de inflamação. Um estudo recente de 10 mulheres submetidas à derivação biliopancreática observou queda nos níveis de PCR, IL-6 e a-defensinas 36 meses após a cirurgia, sem diferença nos níveis de TNF- $\alpha^{122}$. McAuliffe et al. ${ }^{123}$ observaram aumento de monócitos e redução de células dendríticas até 28 dias após cirurgia de DGJYR. Já Vilarrasa et al. ${ }^{124}$ encontraram redução das concentrações séricas de IL-18, receptores de TNF-a e PCR um ano após "bypass" gástrico. O grupo de Cottam et al. ${ }^{64,65,125}$ avaliou apenas marcadores celulares por citometria de fluxo. Estes autores encontraram maior porcentagem de células T CD95+ e menor expressão de CD62L (Lselectina) em obesos mórbidos quando comparados a controles, com redução e aumento, respectivos, destes marcadores, além de queda na 
porcentagem de células CD69+, após a cirurgia. Em outro estudo, a produção de proteína quimiotática de macrófago-1 e de IFN- $\gamma$ por células mononucleares estimuladas por mitógenos foi avaliada em seis pacientes obesos mórbidos antes e após um ano de DGJYR. Observou-se que as concentrações destas citocinas, que eram menores nos obesos antes da cirurgia que nos controles de peso normal, foram restauradas após a perda de peso induzida pela cirurgia ${ }^{126}$.

Sugere-se que a leptina possa atuar como a ligação entre estado nutricional e função imune. Redução dos níveis de leptina é uma das adaptações neuroendócrinas ao jejum e restrição energética ${ }^{127}$. A redução da gordura corporal e a privação nutricional, tipicamente associadas com hipoleptinemia, são causas diretas de imunodeficiência secundária e aumento de susceptibilidade à infecção. A redução dos níveis de leptina durante o jejum foi proposta como mecanismo causal da imunodeficiência associada à desnutrição ${ }^{75}$. Nijhuis et al. $^{128}$ sugerem que a queda nos níveis de leptina possa estar implicada na patogênese de complicações pósoperatórias, como embolia pulmonar, infecção de ferida e sepse, observadas após cirurgia bariátrica. Por outro lado, os dados de Chan et al. ${ }^{129}$ não indicam um papel para a leptina na regulação da função imune em estados de excesso de leptina ou um papel etiológico dos altos níveis de leptina no estado pró-inflamatório associado com a obesidade.

Portanto, o número de estudos que avaliaram parâmetros da função imunológica em pacientes obesos graves e o efeito da perda de peso sobre estes parâmetros é restrito. Além disso, estes estudos incluíram somente 
pequeno número de testes imunológicos, sendo alguns de baixa relevância biológica. Não é claro se o grau de perda de peso induzida pela cirurgia bariátrica influencia a função imune.

Como há pouquíssimos dados na literatura sobre o impacto da perda de peso induzida pela cirurgia de DGJYR no sistema imune, realizamos uma pesquisa mais abrangente da avaliação imunológica nestes pacientes. Procuramos estudar os aspectos da resposta imune potencialmente mais sensíveis às alterações induzidas pela obesidade e conseqüente perda de peso após a cirurgia. Sendo assim, optamos por estudar elementos da resposta imune adaptativa, como a resposta linfoproliferativa e a produção de citocinas Th1 e Th2, e fatores envolvidos na ativação e na atividade das células NK. 
2. OBJETIVOS 


\section{1- Geral}

- Avaliar a influência da perda de peso de pacientes com obesidade grau III submetidos à cirurgia de DGJYR em parâmetros imunológicos.

\section{2- Específicos}

1. Avaliar as concentrações, pré-operatórias e seis meses após cirurgia de DGJYR, de citocinas associadas com a resposta imune adquirida (IL-2, IL4, IL-10 e IFN- $\gamma$ ) e inata (TNF- $\alpha$ e IL-6) de pacientes com obesidade grau III. 2. Estudar o perfil de populações de linfócitos, pré-operatório e seis meses após cirurgia de DGJYR, de pacientes com obesidade grau III.

3. Estudar a função de células NK, pré-operatória e seis meses após cirurgia de DGJYR, de pacientes com obesidade grau III, incluindo seu número em circulação, sua atividade citotóxica e as citocinas associadas a sua função e desenvolvimento (IL-12 e IL-18). 
3. CASUÍSTICA E MÉTODOS 


\section{1- Casuística e Critérios de Inclusão}

Foram avaliados 28 pacientes com obesidade grau III (IMC $\geq 40 \mathrm{~kg} / \mathrm{m}^{2}$ ), na faixa etária $>18$ anos e $<60$ anos, submetidos à cirurgia bariátrica pela técnica de derivação gastrojejunal e reconstrução em $Y$ de Roux (técnica de Fobi-Capella), realizada no Hospital das Clínicas da Faculdade de Medicina de São Paulo (HC/FMUSP) e no Hospital Maternidade São Cristóvão (HMSC).

Foram incluídos vinte mulheres e oito homens, dezesseis brancos e doze não-brancos, com média de idade de 39,9 \pm 10,9 anos (23 a 58 anos) e IMC pré-operatório de 49,5 $\pm 7,1 \mathrm{~kg} / \mathrm{m}^{2}\left(40,1\right.$ a $\left.62,4 \mathrm{~kg} / \mathrm{m}^{2}\right)$. Os pacientes foram submetidos à cirurgia de DGJYR, sendo vinte e três por técnica aberta, entre os quais cinco foram operados no HMSC, e cinco por técnica videolaparoscópica, realizada no HC/FMUSP.

Em relação a doenças associadas, quinze pacientes eram hipertensos, dois apresentavam hipotireoidismo, com anticorpos antitireóide negativos, compensado com reposição, dois apresentavam dislipidemia em tratamento com estatina e um era asmático. Nove mulheres estavam em período após a menopausa e apenas um pacientes era tabagista de um maço de cigarros por semana. Todos pacientes eram sedentários antes da cirurgia.

Os indivíduos que concordaram em participar da pesquisa assinaram um termo de consentimento livre e esclarecido, de acordo com a resolução 
CNS 196/96 do Ministério da Saúde (anexo 1) e aprovado pelo comitê de ética em pesquisa do HC/FMUSP (anexo 2).

\section{2- Critérios de Exclusão}

Foram excluídos pacientes portadores de diabetes mellitus (glicemia em jejum $\geq 126 \mathrm{mg} / \mathrm{dL}$ ou em uso de hipoglicemiantes), doenças auto-imunes em tratamento, neoplasias e infecções crônicas ou que estavam sob uso de drogas imunossupressoras para outras patologias ou ainda aqueles que apresentaram complicações graves no pós-operatório.

\section{3- Métodos}

Os pacientes foram submetidos à mensuração do peso e altura. O peso corporal $(\mathrm{kg})$ foi aferido com a utilização de uma balança digital Filizola®, com capacidade máxima de 300 kg com graduações de 100 em 100 gramas, estando os participantes da pesquisa descalços e com roupas leves. A altura (m) foi determinada por meio de um estadiômetro, graduado em centímetro e com barra de madeira vertical e fixa, com esquadro móvel, para posicionamento sobre a cabeça do indivíduo, estando os mesmos descalços, com os pés unidos, em posição ereta, olhando para frente. Para mensurar o IMC foi dividido o valor do peso $(\mathrm{kg})$ pelo quadrado da altura $\left(\mathrm{m}^{2}\right)$. 
Amostras de até $50 \mathrm{~mL}$ de sangue venoso foram obtidas por punção de veias periféricas. A coleta de sangue foi realizada entre 5 e10 horas da manhã, após, pelo menos, 8 horas de jejum. De cada coleta de sangue, um tubo contendo gel com ativador de coágulo foi encaminhado para o Banco de Sangue do Hospital das Clínicas para a dosagem de ácido fólico e um tubo com heparina sódica e outro tubo contendo gel com ativador de coágulo foram encaminhados para o Laboratório Central do Hospital das Clínicas para a dosagem de zinco e dos outros exames laboratoriais descritos a seguir. O restante do sangue foi coletado em tubos heparinizados e transportado em recipiente refrigerado para o Laboratório de Imunologia do Instituto de Ciências Biomédicas da Universidade de São Paulo, onde foram realizados os experimentos de avaliação dos parâmetros imunológicos. Ao chegar ao Laboratório, este material foi centrifugado a 1500 rotações por minuto (rpm) por 5 minutos a $20^{\circ} \mathrm{C}$ e as alíquotas de plasma separadas foram estocadas em freezer a $-20^{\circ} \mathrm{C}$ para a dosagem da leptina, a qual foi realizada em um só tempo, após a finalização de todas as coletas antes e após a cirurgia.

No primeiro mês pós-operatório, os pacientes foram orientados a consumir dieta hipocalórica e sem introdução de medicação polivitamínica. A dieta orientada foi dividida em fases, a fim de prevenir complicações e efeitos colaterais indesejáveis associados com a reestruturação anatômica e alterações fisiológicas resultantes da cirurgia ${ }^{130}$. A primeira fase da dieta, feita na fase de internação hospitalar, foi composta por dieta líquida restrita, como chás, isotônicos, caldos (legumes e carne), água e água de coco. A 
segunda fase, com duração de duas semanas, foi composta por dieta líquida completa, como sucos, isotônicos, caldos (legumes e de carne), leite, bebida láctea e fórmulas suplementares pobres em resíduos. O volume variou de 30 a $60 \mathrm{~mL}$ de hora em hora, evoluindo gradativamente de acordo com a tolerância do paciente. A partir de então, até o término do primeiro mês após a cirurgia ou conforme a tolerância individual, os pacientes foram orientados a consumir dieta líquida-pastosa (caldo de feijão, leite, vitaminas, sucos, iogurtes, sopas liquidificadas e purês etc). O volume variou de 50 a $90 \mathrm{~mL}$ de hora em hora, evoluindo gradativamente, e estimulou-se o consumo de 1500 $\mathrm{mL}$ por dia. Já a partir do primeiro mês, os pacientes foram orientados ao consumo de alimentos ricos em vitaminas e sais minerais, especialmente, em vitamina B12, ácido fólico, zinco, ferro e cálcio, sem restrição quanto à consistência e receberam um esquema dietético adaptado à tolerância individual. A reposição com polivitamínico foi prescrita a partir de um mês após a cirurgia. $O$ polivitamínico recomendado foi Materna ${ }^{\circledR}$, já que corresponde a um dos mais ricos em ácido fólico, ferro e zinco disponíveis no mercado, além de conter várias vitaminas e minerais essenciais, formando um composto bem balanceado para reposição segundo as necessidades dietéticas diárias. A composição deste polivitamínico e a ingestão diária recomendada (IDR) para homens e mulheres $>18$ e $<70$ anos $^{131}$ estão contidas na tabela 1. 
Tabela 1. Composição das principais vitaminas e minerais contidos no polivitamínico Materna ${ }^{\circledR}$ e a ingestão diária recomendada para homens e mulheres $>18$ e $<70$ anos

\begin{tabular}{llll}
\hline Componentes & Materna $\mathbb{~}$ & IDR Homens & IDR Mulheres \\
\hline Vitamina A (UI) & 5000 & 3000 & 2333 \\
Tiamina (mg) & 3 & 1,2 & 1,1 \\
Riboflavina (mg) & 3,4 & 1,3 & 1,1 \\
Niacina (mg) & 20 & 16 & 14 \\
Biotina (mcg) & 30 & 30 & 30 \\
Ácido Pantotênico (mg) & 10 & 5 & 5 \\
Piridoxina (mg) & 10 & $1,3-1,7$ & $1,3-1,5$ \\
Cianocolabamina (mcg) & 12 & 2,4 & 2,4 \\
Vitamina C (mg) & 100 & 90 & 75 \\
Vitamina D (UI) & 400 & $200-400$ & $200-400$ \\
Vitamina E (UI) & 30 & 10 & 10 \\
Ácido Fólico (mg) & 1 & 0,4 & 0,4 \\
Cálcio (mg) & 250 & 1000 & 1000 \\
Cobre (mg) & 2 & 0,9 & 0,9 \\
Cromo (mcg) & 25 & $30-35$ & $20-25$ \\
Ferro (mg) & 60 & 8 & $8-18$ \\
lodo (mcg) & 150 & 150 & 150 \\
Magnésio (mg) & 25 & $400-420$ & $310-320$ \\
Manganês (mg) & 5 & 2,3 & 1,8 \\
Zinco (mg) & 25 & 11 & 8 \\
\hline
\end{tabular}

IDR- ingestão diária recomendada

\subsection{1- Exames laboratoriais}

Além da dosagem de glicemia, colesterol total (CT), HDL-colesterol (col) e triglicerídeos (TG), foram também analisados cálcio ionizado, magnésio, zinco, ferro, ácido fólico e leptina.

Glicemia: foi determinada pelo método da hexoquinase, no equipamento Hitachi Modular P [Roche Diagnóstica Brasil Limitada (Ltda)]. Valor de referência (VR): 70 a $100 \mathrm{mg} / \mathrm{dL}$. 
Lípides: as dosagens de CT, TG e LDL-col foram determinadas pelo método enzimático colorimétrico e a dosagem de HDL-col, por método direto. Estas dosagens foram realizadas em sistema automatizado Hitachi Modular P (Roche Diagnóstica Brasil Ltda).

Cálcio ionizado: foi determinado pelo método eletrodo íon seletivo, no equipamento AVL 9180 (Roche Diagnóstica Brasil Ltda). VR: 4,6 a 5,3 $\mathrm{mg} / \mathrm{dL}$.

Magnésio: foi determinado pelo método colorimétrico, no equipamento Hitachi Modular P (Roche Diagnóstica Brasil Ltda). VR: 1,58 a 2,55 mg/dL.

Zinco: foi determinado pelo método de espectrofotometria de absorção atômica. VR: 50 a $150 \mu \mathrm{g} / \mathrm{dL}$.

Ferro: foi determinado pelo método colorimétrico sem desproteinização, no equipamento Hitachi Modular P (Roche Diagnóstica Brasil Ltda). VR em mulheres: 37 a $145 \mu \mathrm{g} / \mathrm{dL}$ e em homens: 59 a $158 \mu \mathrm{g} / \mathrm{dL}$.

Ácido fólico: foi determinado pelo método de quimioluminescência, no equipamento Access (Sanofi). VR: 3 a $17 \mathrm{mEq} / \mathrm{mL}$.

Leptina: foi determinada pelo método de ensaio de imunoadsorção ligado à enzima (ELISA) (Linco Inc). O menor nível de leptina que pode ser detectado por este método é de $0,5 \mathrm{ng} / \mathrm{mL}$. As análises foram realizadas em duplicatas. 


\subsection{2- Avaliação imunológica}

Obtenção de células mononucleares a partir de sangue periférico

As células mononucleares de sangue periférico (PMBC) foram separadas por gradiente de centrifugação sobre Isolymph (GallardSchlesinger Industries, Inc, Norway) a $970 \mathrm{~g}$ por 20 minutos a $20^{\circ} \mathrm{C}$. A interface contendo a camada de células mononucleares foi lavada uma vez com solução salina tamponada (PBS) $\left(\mathrm{NaCl} 0.14 \mathrm{M} ; \mathrm{Na}_{2} \mathrm{PO}_{4} 0.01 \mathrm{M} ; \mathrm{pH} 7.2\right)$ (centrífuga a $450 \mathrm{~g}$ por 5 minutos a $4{ }^{\circ} \mathrm{C}$ ) e, a seguir, foi adicionado $1 \mathrm{~mL}$ de meio de Eagle modificado por Dulbecco (DMEM) com soro humano $\mathrm{AB}^{+}$ (CAMBREX) a $5 \%$ suplementado estéril. Após a contagem das células em câmara, deste material foram separadas alíquotas para o ensaio de proliferação de célula $T$ em presença de mitógeno, para quantificação de células por citometria de fluxo e para a determinação da atividade de células NK em meio de cultura.

\section{Ensaio de proliferação de célula T em presença de mitógeno}

A proliferação das células foi avaliada pela técnica convencional de captação de timidina triciada medida por cintilação líquida. $O$ ensaio de proliferação de células $T$ na presença de mitógeno policlonal foi executado em DMEM ou meio Royal Park Memorial Institute (RPMI) 1640 contendo alta concentração de glucose $(4.500 \mathrm{mg} / \mathrm{L})$. O meio de cultura foi suplementado com aminoácidos não essenciais $0.1 \mathrm{mM}$, vitaminas $0.1 \mathrm{mM}$, piruvato de sódio $1 \mathrm{mM}$, L-glutamina $2.0 \mathrm{mM}$, e mercaptoetanol 10-5M. As PBMC $\left(2 \times 10^{5}\right.$ 
células/poço) foram submetidas a três lavagens em meio de cultura contendo $0.5 \%$ de soro humano $A B+e$ as células foram adicionadas em triplicatas a placas de 96 poços para cultura, num volume final de $200 \mu \mathrm{L}$ de meio contendo $5 \%$ soro humano $\mathrm{AB}+$. Como controle da viabilidade celular e de sua habilidade de proliferar em meio de cultura, todos os experimentos contiveram como controle estimulação por fitohemaglutinina (PHA) a 5 $\mu \mathrm{g} / \mathrm{mL}$. A proliferação basal foi medida em poços contendo apenas as células testadas em meio de cultura. A resposta proliferativa foi avaliada 48 horas após o estímulo com PHA a $5 \mu \mathrm{g} / \mathrm{mL}$.

\section{Dosagem de citocinas produzidas por PMBC}

As diversas citocinas foram avaliadas no sobrenadante coletado após estimulação das células mononucleares por PHA e dosadas pela técnica de ELISA de "sandwiche" com pares de anticorpos. Todas as determinações de citocinas pelo método de ELISA seguiram um protocolo semelhante de acordo com as sugestões do fornecedor dos anticorpos. Placas de 96 poços de alta afinidade Costar para imunoensaio enzimático foram cobertas por 18 horas a $4^{\circ} \mathrm{C}$ com a quantidade apropriada do anticorpo de captura específico para a citocina medida, usando tampão de carbonato/bicarbonato de sódio

0.5M, pH 9.6 ou tampão de bicarbonato de sódio $0.5 \mathrm{M}, \mathrm{pH} 8.2$. A concentração final de anticorpo foi determinada previamente por meio de curvas comparativas, usando interleucinas recombinantes dentro do intervalo sugerido pelo fornecedor. As placas assim cobertas foram lavadas 4 vezes com tampão de lavagem (PBS, pH 7.4, 0.01\% Tween 20, 0.01\% timerosal), e 
submetidas a bloqueio dos sítios não cobertos pelo anticorpo de captura em PBS estéril contendo $2.5 \%$ de albumina sérica bovina por um mínimo de 2 horas. O tampão de lavagem foi então aspirado, e as amostras e a curva padrão com a citocina apropriada, foram depositadas nas placas. Após 2 horas sob agitação (150 rpm em um agitador horizontal), as placas foram lavadas 4 vezes como descrito acima, e o anticorpo secundário marcado com biotina foi depositado na concentração apropriada previamente estabelecida (vide acima). Após 2 horas de incubação, sob as mesmas condições das amostras, as placas foram lavadas 6 vezes, e estreptavidina marcada com peroxidase de rabanete selvagem (HRPO) foi adicionada por 1 hora a $37^{\circ} \mathrm{C}$. As placas foram lavadas 8 vezes, e o substrato diluído em tampão citrato 0.2 M, pH 5.0 foi adicionado [ambos ø-fenileno-diamina (OPD) ou ácido 2,2'azino-bis-(3-etilbenzotiazolina)-6-sulfônico (ABTS) foram utilizados]. Entre cinco e vinte minutos após a adição do substrato, a reação foi interrompida usando solução de H2SO4.2N, e a leitura das absorbâncias foi feita usando um leitor de ELISA da Molecular Devices (Mountain View, CA, EUA), e o programa Vectra que o acompanha na versão para computadores Apple/Macintosh. Quando o substrato usado foi OPD, a leitura foi feita num comprimento de onda de $490 \mathrm{~nm}$, ou $405 \mathrm{~nm}$ quando o substrato usado foi ABTS.

\section{$\underline{\text { Fenotipagem de células por citometria de fluxo }}$}

A citometria de fluxo é uma técnica na qual, através de um sistema de fluidos, partículas microscópicas em suspensão aquosa (células) são 
levadas a passar "em fila indiana" através de um feixe de laser, e ao passar por esse feixe de laser, gera sinais luminosos que são:

- "Forward light scatter" (FSC): dispersão frontal do feixe de laser provocado pela partícula e que fornece um parâmetro relativo do tamanho da partícula.

- "Side scatter" (SSC): dispersão lateral do feixe de laser provocado pela partícula e que fornece um parâmetro relativo da granulosidade ou complexidade interna da partícula.

O citômetro também pode detectar sinais luminosos específicos procedentes de moléculas flourescentes, ou seja, estes compostos absorvem luz no comprimento de onda do laser (simbolizado por $\mathrm{H}$; por exemplo, 488nm), e emite luz em um comprimento de onda diferente (por exemplo, 530nm). O citômetro possui um aparato óptico que permite a distinção entre estes sinais luminosos.

Ao conjugar anticorpos específicos para proteínas presentes na membrana das células com esses fluorocromos, é possível detectar quais células possuem ou não a estrutura reconhecida pelo anticorpo em sua superfície. Além disto, o aparelho é capaz de detectar a intensidade de fluorescência emitida por cada célula e, deste modo, é possível distinguir não somente entre positivo e negativo, mas também é possível analisar, novamente de maneira relativa, se expressam maior ou menor quantidade da proteína em sua membrana. 
Com o uso de fluorocromos de cores diferentes conjugados a anticorpos diferentes, é possível o estudo da presença de diversas estruturas simultaneamente na mesma célula.

Finalmente, com os dados produzidos pelo citômetro são gerados arquivos de banco de dados que são analisados em softwares específicos.

A figura 3 representa um esquema de funcionamento de um citômetro de fluxo. 


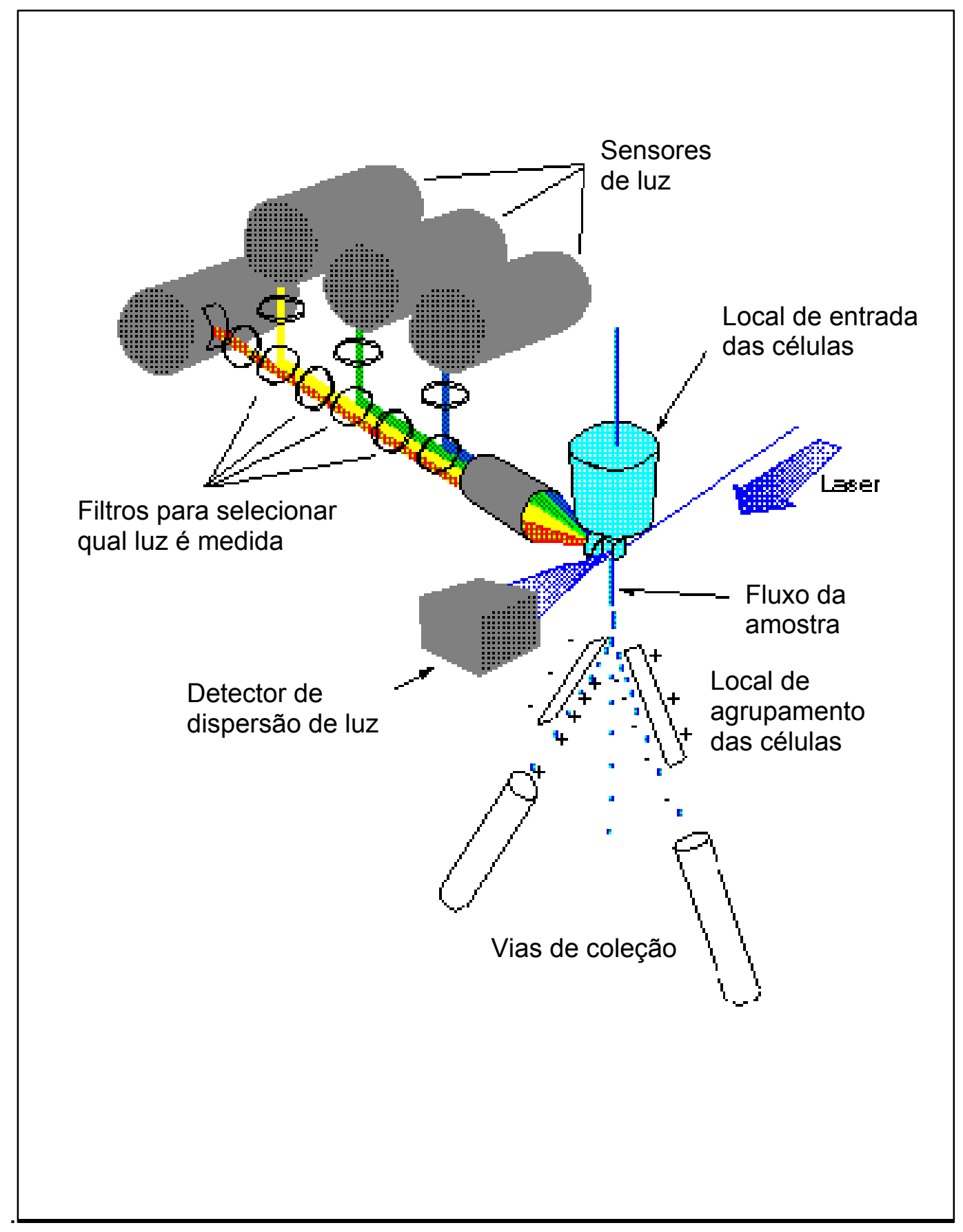

Figura 3: Representação esquemática de um citômetro de fluxo. As células marcadas são levadas ao citômetro, que possui um laser que excita a molécula corada ligada à célula, tornando-a fluorescente, permitindo sua leitura pelo aparelho.

Optamos por representar os dados obtidos no citômetro de fluxo em um diagrama denominado "dot plot" e expressar os resultados em porcentagem. Cada tipo celular tem determinada distribuição conforme tamanho e 
granulosidade, o que gera um diagrama semelhante ao exemplificado na figura 4. Para obter nossos resultados, utilizamos a região que corresponde ao tamanho e granulosidade de linfócitos ("gating" de linfócitos).

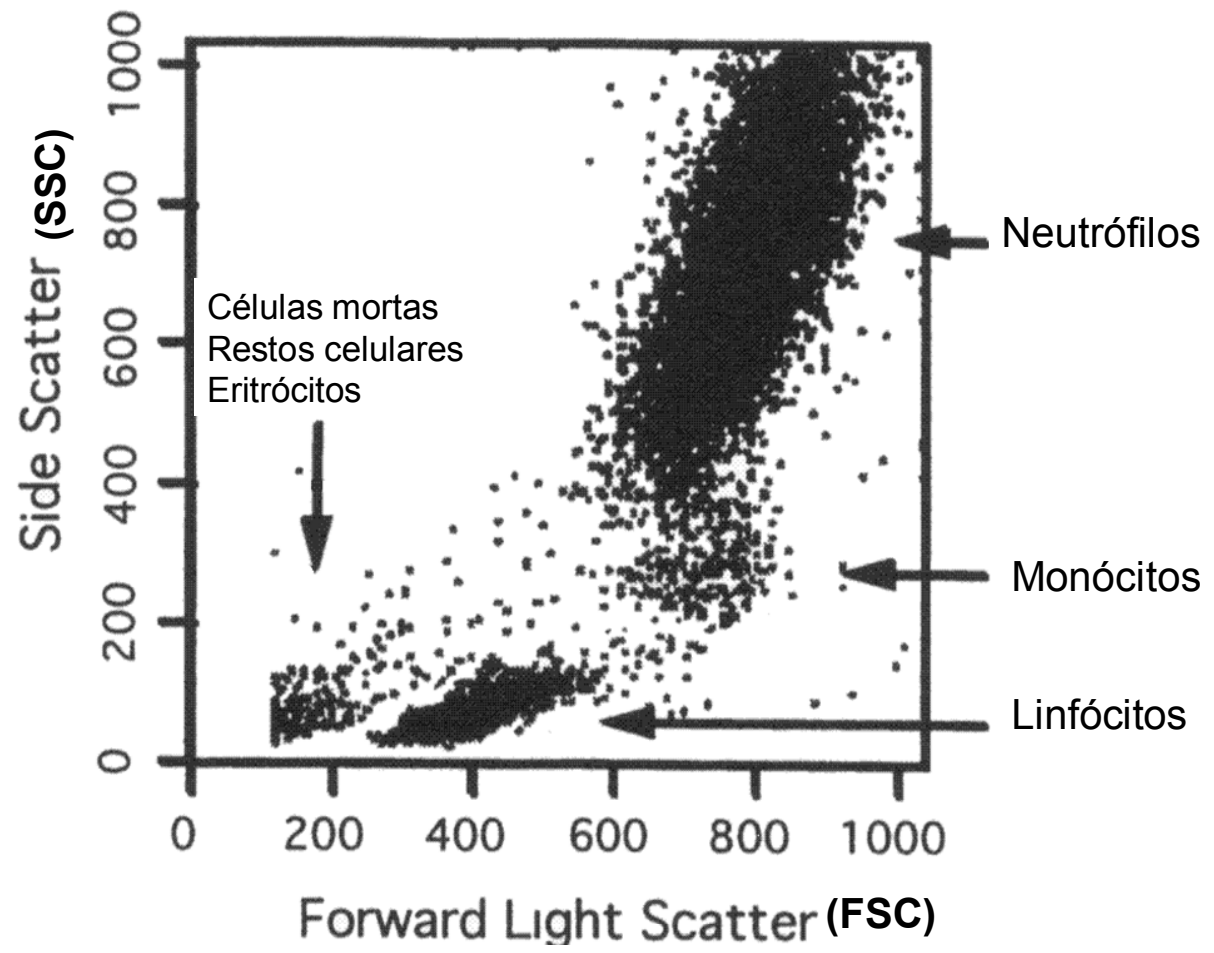

Figura 4: Diagrama em "dot plot" da distribuição de células obtidas de sangue periférico segundo análise de tamanho (FSC) e granulosidade (SSC).

Alíquotas de $1,0 \times 10^{6}$ células/mL diluídas em DMEM com soro humano $\mathrm{AB}^{+}$a $5 \%$ suplementado estéril foram incubadas com anticorpos monoclonais anti-CD3/CD4/CD8, anti-CD4/CD25, anti-CD16/CD56, anti-CD4/CD95, antiCD8/CD95, anti-CD19/CD69/CD45, anti-CD45RA/CD45RO e antiCD3/CD45RA conjugados com isotiocianato de fluoresceína (FITC), ficoeritrina (PE) ou Cy-Cromo (Cy), além de controle isotípico apropriado, durante 30 minutos à temperatura ambiente e protegido da luz. A seguir, uma lavagem com PBS e duas lavagens com PBS com soro humano $\mathrm{AB}^{+}$a $3 \%$ 
foram efetuadas. As hemácias foram lisadas com 2,0 mL de tampão de lise

de hemáceas $\left(F A C S^{R}\right.$ Lysing Buffer) à temperatura ambiente durante 10 minutos ao abrigo de luz. As suspensões celulares foram submetidas à leitura em citômetro de fluxo (FACScan - Becton Dickinson, Sunnyvale, CA), onde foram analisadas 10.000 células, utilizando como parâmetros: FSC-H x SSC-H, número de células $x$ fluorocromo $(F L)_{1}-\mathrm{H}$, número de células $x \mathrm{FL}_{2}-\mathrm{H}$, número de células $\times \mathrm{FL}_{3}-\mathrm{H}, \mathrm{FL}_{1}-\mathrm{H} \times \mathrm{FL}_{2}-\mathrm{H}, \mathrm{FL}_{1}-\mathrm{H} \times \mathrm{FL}_{3}-\mathrm{H}$ e $\mathrm{FL}_{2}-\mathrm{H} \times \mathrm{FL}_{3}-\mathrm{H}$.

\section{Determinação de atividade de células NK}

A atividade de células NK foi medida pelo ensaio de liberação enzimática de 4 horas. A citotoxicidade foi avaliada pela mensuração da atividade de desidrogenase láctica (LDH) liberada no sobrenadante pela lise de células alvo (K562), de acordo com o método de Korzeniewski and Callewaert $^{132}$. As células alvo K562 são células de linhagem leucêmica, MHC classe I negativas, o que as tornam alvo preferencial de células NK. As células alvo K562, selecionadas no laboratório para máxima susceptibilidade a lise, foram misturadas com PBMC (efetores) em diferentes proporções células efetoras:células alvo (40:1, 20:1, 10:1, 5:1 e 1:1). A atividade de LDH foi determinada por método colorimétrico, realizado no aparelho Ultramax 180 e analisada usando o programa Soft-Max PRO 8.9 (Molecular Devices Corporation, Menlo Park, USA). Os dados sobre a atividade das células NK das células PBMC incubadas por 4 horas com ou sem modificadores foram expressas como percentual (\%) de lise. 
Usando o desenho de placa abaixo:

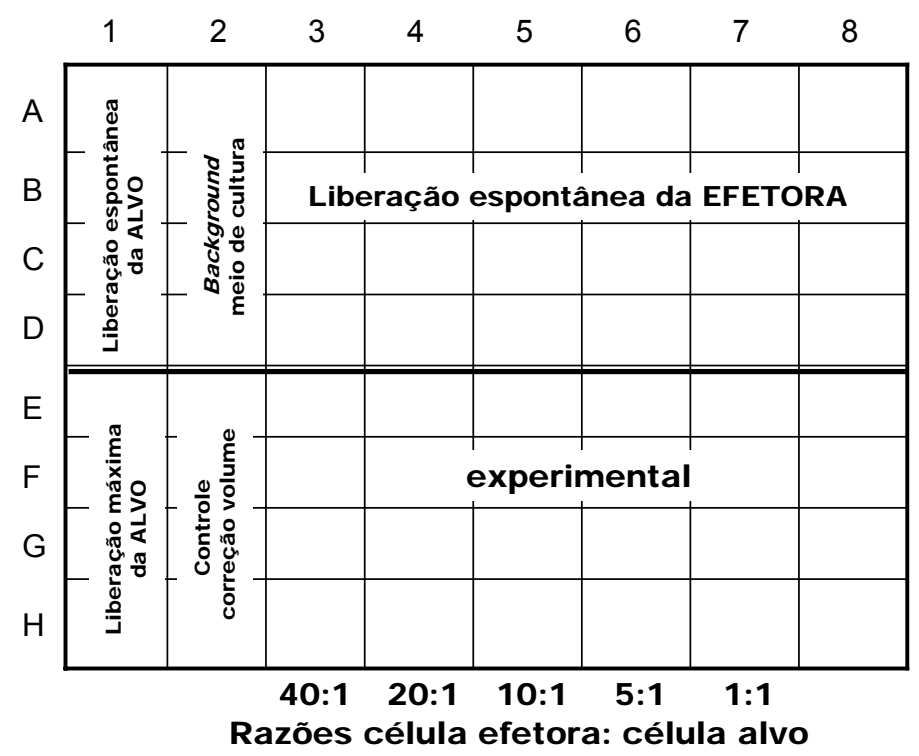

Figura 5: Representação esquemática da placa de cultura de células para realização do ensaio de células NK. Adiciona-se um número constante de células alvo aos poços experimentais e acrescenta-se células efetoras, criando proporções de células efetoras (PBMC): célula alvo (células K562) de 40:1, 20:1, 10:1, 5:1 e 1:1 nos poços para testar a liberação de LDH em cada razão células efetoras:célula alvo.

1. Liberação espontânea de LDH de células efetoras: adicionou-se somente células efetoras a cada concentração usada no plaqueamento experimental em quadruplicatas. O volume final foi o mesmo dos poços experimentais.

2. Poços experimentais: adicionou-se o número constante de células alvo (determinado na seção 1) a todos os poços experimentais de uma placa de 96 poços de fundo redondo. Adicionaram-se vários números de células efetoras em quadruplicatas (proporção células efetora:célula alvo 40:1 a 1:1) de poços para testar a razão célula efetora:célula alvo. O volume final combinado foi de $200 \mu \mathrm{L} /$ poço. 
3. Liberação espontânea de LDH de células alvo: adicionou-se células alvo (na concentração determinada na seção 1) em quadruplicatas. O volume final foi o mesmo dos poços experimentais.

4. Liberação máxima de LDH de células alvo: adicionou-se células alvo (na concentração determinada na seção 1) em quadruplicatas. O volume final foi o mesmo dos poços experimentais. Adicionou-se $10 \mu$ da solução de lise (10X) por $100 \mu \mathrm{L}$ de meio de cultura. Isto resultou na concentração de $0,8 \%$ de Triton X-100, que completou a lise das células alvo. Já que concentrações de células K562 acima de $5 \times 10^{5}$ células excedem a faixa linear do ensaio, alíquotas de células alvo foram incubadas na presença da solução de lise por 45 minutos antes da coleta do sobrenadante para determinar a liberação máxima de LDH da maior concentração de células alvo K562.

5. Correção do volume do controle: adicionou-se $10 \mu \mathrm{L}$ da solução de lise (10X) às quadruplicatas de poços contendo $100 \mu \mathrm{L}$ de meio de cultura (sem células). Este controle é recomendado para corrigir o maior volume causado pela adição da solução de lise (10X). Esta mudança de volume afeta a concentração de vermelho fenol e soro, que contribui para a leitura da absorbância.

6. Background do meio de cultura: adicionou-se $100 \mu \mathrm{L}$ de meio de cultura em quadruplicatas. Este controle é necessário para corrigir as contribuições causadas pelo vermelho fenol e atividade LDH que possam estar presentes no meio de cultura com soro.

7. Controle positivo LDH: foi usado controle positivo (LDH de coração bovino) para verificar a "performance" de outros componentes do sistema. Misturou- 
se, gentilmente, o controle positivo LDH por vórtex e, então, diluiu-se $2 \mu \mathrm{L}$ desta solução em $10 \mathrm{~mL}$ de PBS + 1\% BSA (1:5.000). Esta solução foi preparada no momento de uso. O volume final foi o mesmo dos poços experimentais. A diluição do controle positivo LDH a 1:5.000 dá aproximadamente o mesmo valor da enzima encontrada em 13.500 células K562 lisadas.

8. A placa foi centrifugada a $250 \mathrm{~g}$ por 4 minutos, para assegurar o contato da célula efetora e célula alvo.

Cálculo dos resultados:

1. Subtrair a média dos valores de absorbância do background do meio de cultura de todos os valores de absorbância experimental, liberação espontânea de LDH de células alvo e liberação espontânea de LDH de células efetoras.

2. Subtrair a média dos valores de absorbância do controle de correção de volume dos valores de absorbância obtidos do controle de liberação de LDH máximo da célula alvo.

3. Usar os valores corrigidos obtidos nos itens 1 e 2 na fórmula seguinte para computar o percentil de citotoxicidade para cada razão células efetora:célula alvo.

$\%$ citotoxicidade $=$ experimental - efetora espontânea - alvo espontânea X 100 alvo máxima - alvo espontânea 


\section{Exemplo:}

experimental (10:1; média) - background do meio de cultura (média):

$0,819-0,464=0,355$

espontâneo da célula alvo (média) - background do meio de cultura (média):

$0,472-0,464=0,187$

espontâneo da célula efetora (média) - background do meio de cultura (média) : 0,651-0,464 =0,187

máximo da célula alvo (média) - controle da correção de volume (média):

$0,659-0,444=0,215$

$\%$ citotoxicidade para a razão $40: 1=\underline{0,355-0,187-0,008} \times 100=80 \%$

$$
0,215-0,008
$$

\section{4- Análise estatística}

A condição de normalidade das variáveis foi avaliada pelo teste de Shapiro-Wilks. Para verificação das diferenças entre os dois tempos de análise em relação aos dados antropométricos e exames laboratoriais, utilizamos o teste $\mathrm{t}$ de Student. Os resultados foram apresentados como média \pm desvio padrão. $O$ teste de Wilcoxon foi utilizado para verificar a existência de diferenças entre os dois tempos de análise em relação aos parâmetros imunológicos avaliados, exceto para a atividade citotóxica. O teste de Fisher foi usado para as análises da atividade citotóxica das células NK, sendo usado para a análise individual dos dados o teste de ANOVA, que 
foram realizados no programa Stat View 4.5. O programa GraphPad Prism versão 3.0 foi usado para o restante das análises estatísticas. 
4. RESULTADOS 


\section{1- Peso corporal e exames laboratoriais}

A perda de peso foi de $35,3 \pm 4,5 \mathrm{~kg}$ no $6^{\circ}$ mês após a cirurgia, o que correspondeu a uma perda de $25,9 \%$ do peso inicial. Houve uma significativa redução no IMC após 6 meses da cirurgia $\left(-12,9 \pm 0,9 \mathrm{~kg} / \mathrm{m}^{2}, p<0,001\right)$ (figura 6).

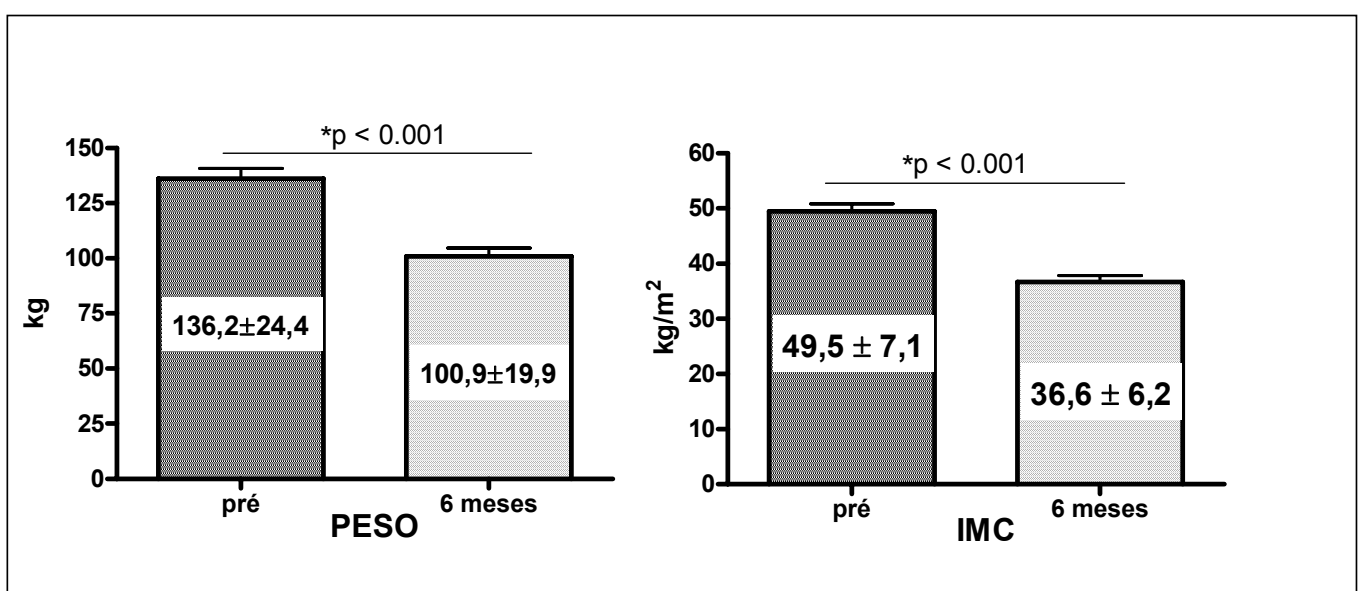

Figura 6: Dados antropométricos dos pacientes $(n=28)$ no pré-operatório e seis meses após a cirurgia. * teste t de Student.

A tabela 2 mostra os resultados dos exames laboratoriais realizados antes e após a cirurgia. Pela análise estatística dos valores obtidos antes e seis meses após a cirurgia, houve redução significativa nas concentrações séricas de glicemia, colesterol total, triglicerídeos, LDL-col e ferro e aumento na concentração sérica de cálcio após o procedimento cirúrgico. Além disto, as concentrações plasmáticas de leptina também reduziram, corroborando trabalhos prévios de outros grupos ${ }^{133}$. 
Tabela 2. Exames laboratoriais dos pacientes $(n=28)$ no pré-operatório e seis meses após a cirurgia

\begin{tabular}{lll}
\hline Parâmetro laboratorial & Pré & 6 meses \\
\hline Glicemia $(\mathrm{mg} / \mathrm{dL})$ & $90,8 \pm 12,8$ & $80,2 \pm 9,5^{*}$ \\
Colesterol total $(\mathrm{mg} / \mathrm{dL})$ & $211,8 \pm 34,8$ & $173,8 \pm 34,7^{*}$ \\
Triglicerídeos $(\mathrm{mg} / \mathrm{dL})$ & $163,7 \pm 107,1$ & $105,7 \pm 39,5^{*}$ \\
HDL-col $(\mathrm{mg} / \mathrm{dL})$ & $50,2 \pm 11,5$ & $52,9 \pm 9,9$ \\
LDL-col $(\mathrm{mg} / \mathrm{dL})$ & $132,5 \pm 31,7$ & $99,7 \pm 28,6^{*}$ \\
Cálcio iônico $(\mathrm{mg} / \mathrm{dL})$ & $4,9 \pm 0,17$ & $5,0 \pm 0,16^{*}$ \\
Magnésio $(\mathrm{mg} / \mathrm{dL})$ & $2,34 \pm 0,52$ & $2,18 \pm 0,17$ \\
Zinco $(\mu \mathrm{g} / \mathrm{dL})$ & $81,7 \pm 15,9$ & $79,3 \pm 15,5$ \\
Ferro $(\mu \mathrm{g} / \mathrm{dL})$ & $100,5 \pm 44,8$ & $87,8 \pm 31,9 \dagger$ \\
Ácido fólico $(\mathrm{ng} / \mathrm{mL})$ & $8,8 \pm 3,0$ & $9,5 \pm 4,8$ \\
Leptina $(\mathrm{ng} / \mathrm{mL})$ & $105,6 \pm 87,2$ & $29,0 \pm 19,9^{*}$ \\
\hline
\end{tabular}

Dados expressos como média \pm desvio-padrão. ${ }^{*} \mathrm{p}<0,01+\mathrm{p}=0,03$ teste t de Student.

\section{2- Parâmetros imunológicos}

\subsection{1- Ensaio de proliferação de linfócitos $T$ em presença de mitógeno}

Os resultados são apresentados como índice de estimulação (IE): razão da proliferação média ao dado estímulo pela proliferação média das células não estimuladas.

Na figura 7, a qual representa graficamente os valores do IE no pré e pós-operatório, observamos aumento significativo da proliferação de linfócitos seis meses após a cirurgia. O IE aumentou em mais de $78 \%$ dos pacientes $(n=22)$ após a cirurgia. Este aumento variou de 3,2 a $3309 \%$ (mediana: 341,2\%). 


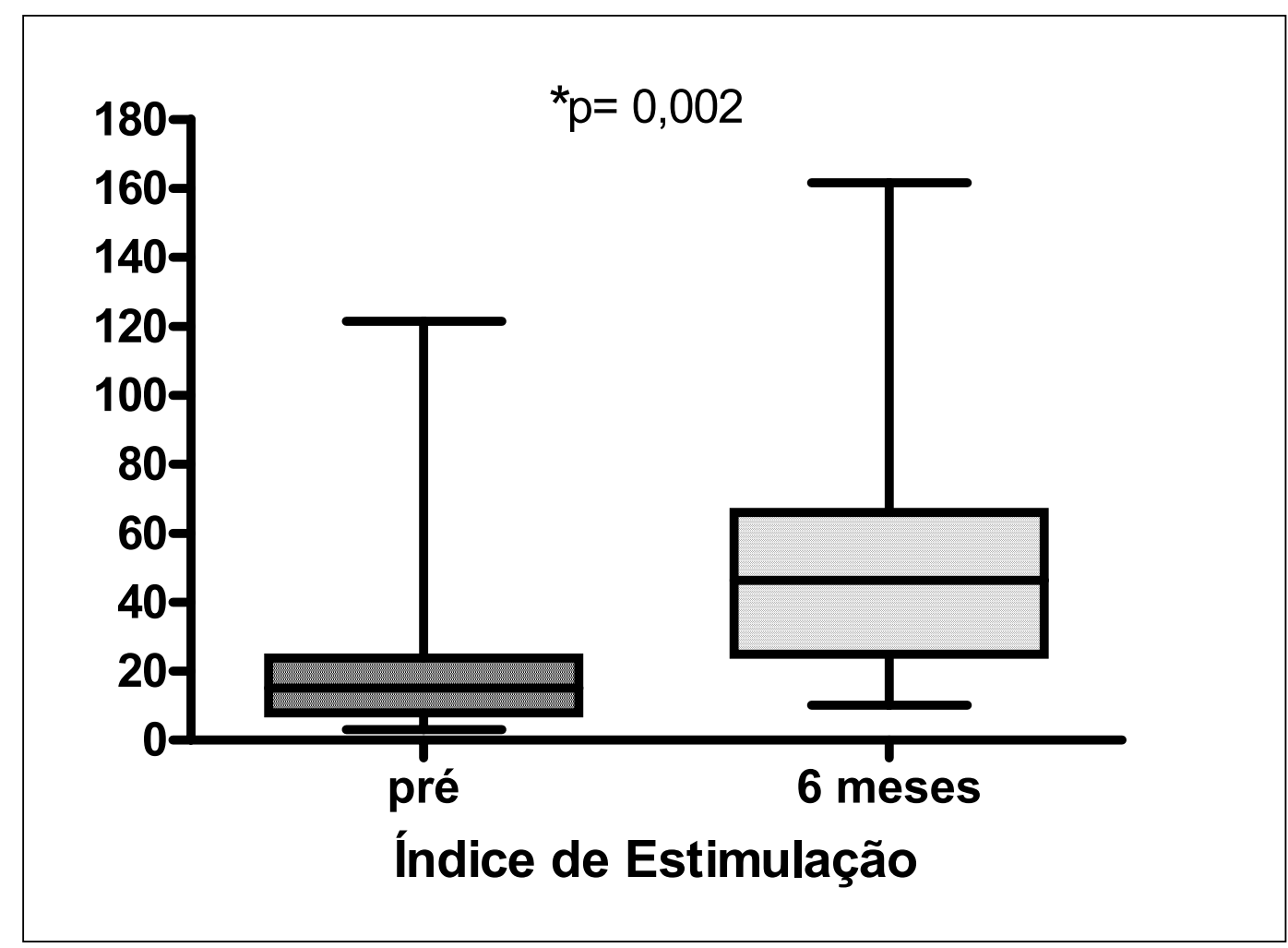

Figura 7: Expressão em "dot plot" do índice de estimulação (IE) dos pacientes $(n=28)$ no pré-operatório e seis meses após a cirurgia. O IE representa a razão da proliferação média de linfócitos T ao estímulo com $5 \mu \mathrm{g} / \mathrm{mL}$ de PHA pela proliferação média das células não estimuladas. ${ }^{*}$ teste de Wilcoxon.

\subsection{2- Produção de citocinas por células mononucleares após} estimulação com mitógeno

Foram dosadas citocinas pró e antiinflamatórias de origem linfocitária ou não, envolvidas primariamente na resposta imune adaptativa, mas também na resposta imune inata. Assim, das citocinas de padrão Th1 (IL-2, IFN- $\gamma$, IL12 e IL-18), encontramos aumento significativo nos níveis de produção de IFN- $\gamma$, IL-12 e IL-18 (Figura 8), enquanto a IL-2 apresentou uma tendência ao aumento $(p=0,07)$. As demais citocinas não apresentaram variação significativa seis meses após a cirurgia. 

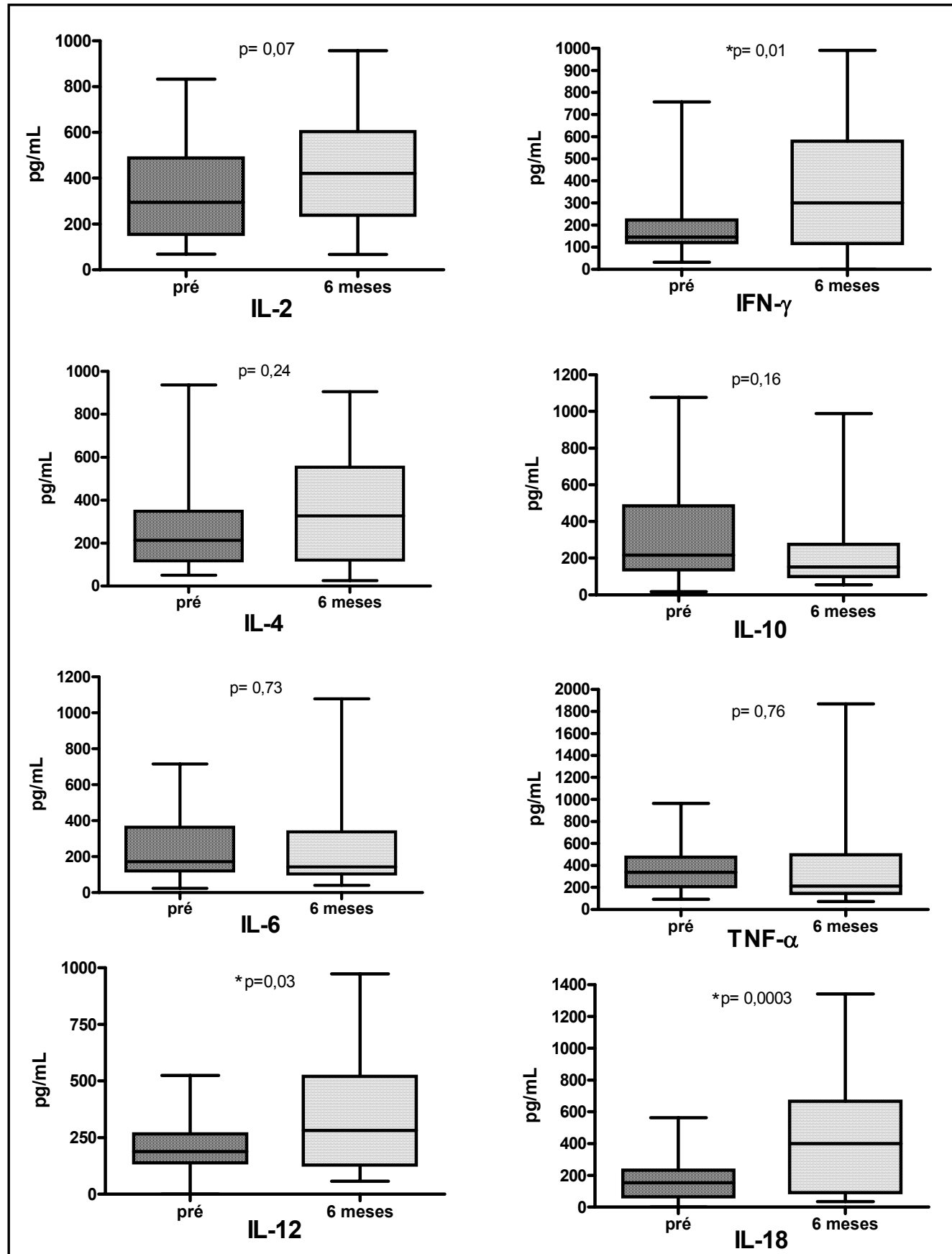

Figura 8. Expressão em "dot plot" das concentrações de citocinas produzidas por células mononucleares dos pacientes ( $n=28$, exceto para IL-2 e IL-12 cujo $n=27$ ) no pré-operatório e seis meses após a cirurgia. PBMC foram isoladas e plaqueadas com 5 $\mu \mathrm{g} / \mathrm{mL}$ of PHA. As citocinas foram medidas por ELISA nos sobrenadantes recolhidos. *Houve aumento pós-operatório nas concentrações de IFN- $\mathrm{y}$, IL-12 e IL-18. O teste de Wilcoxon foi aplicado para comparação dos dados nos dois tempos. 
Na figura 9 são apresentados os gráficos que mostram a freqüência de pacientes que apresentaram redução ou aumento, este por faixa percentual, nas concentrações das citocinas produzidas por PBMC após estímulo com PHA, que foram estudadas após seis meses da cirurgia.
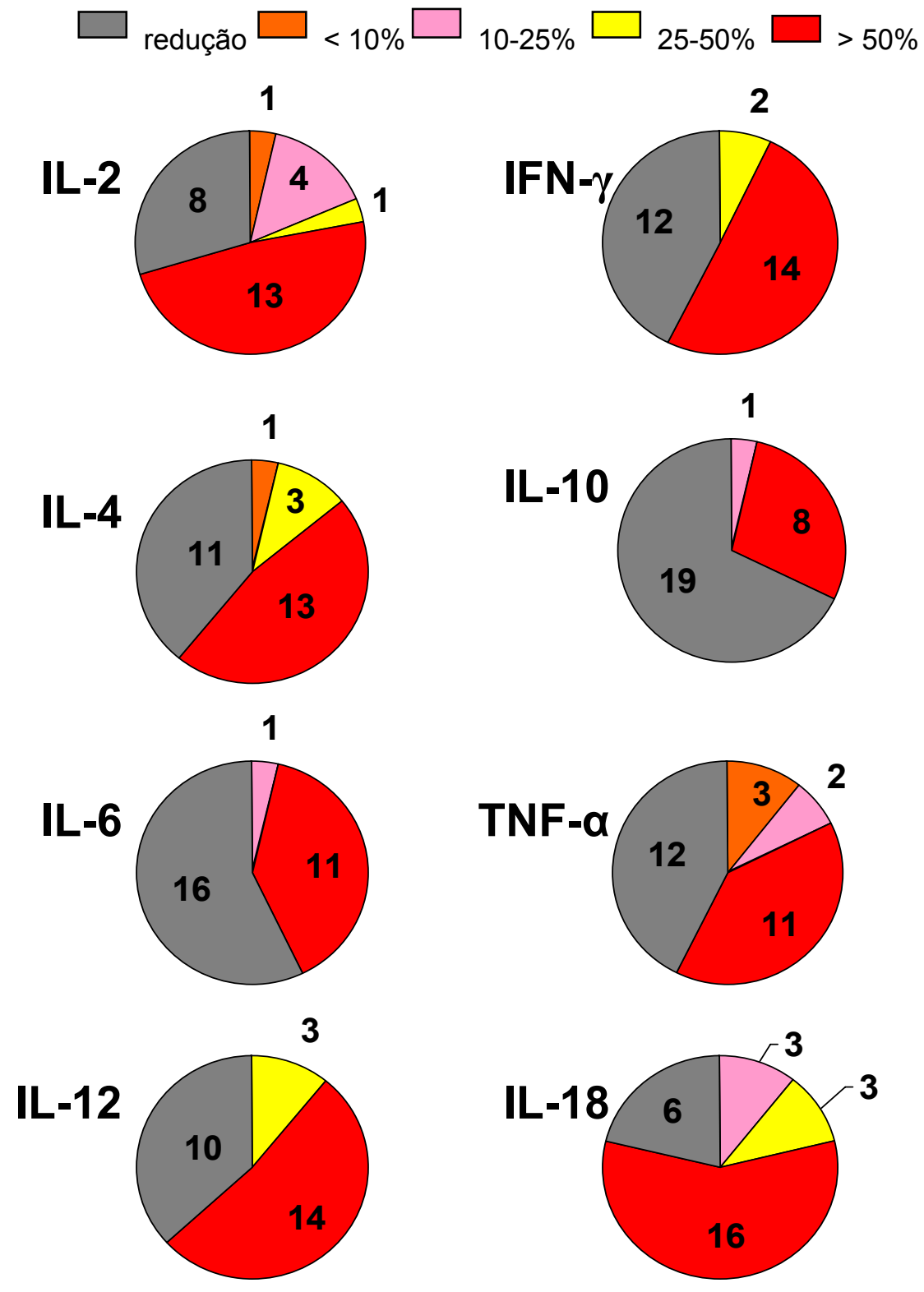

Figura 9. Número absoluto de pacientes que apresentaram redução ou aumento (por faixa percentual de aumento: $<10 \%$, entre $10-25 \%$, entre $25-50 \%$ e $>50 \%$ ) nas concentrações das citocinas produzidas por PBMC após estímulo com PHA. 
4.2.3- Fenotipagem de populações celulares mononucleares obtidas do sangue periférico por citometria de fluxo

Avaliamos populações celulares por citometria de fluxo, com o objetivo de detectar possíveis alterações nos subtipos de células $T$ e B. Os marcadores de superfície CD3, CD4, CD8 e CD19 foram avaliados em combinação com os marcadores de ativação e diferenciação CD45RA e CD45R0, CD95, CD25 e CD69. Além disto, o marcador de superfície CD56 foi utilizado para detecção das células NK. Os resultados foram expressos em porcentagem e em relação ao "gating" de linfócitos.

$\mathrm{Na}$ figura 10 estão representados os gráficos das porcentagens dos marcadores de superfície das populações celulares de linfócitos Th (CD3/CD4) e Tc (CD3/CD8), da relação entre linfócitos "naïve" e de memória (CD45RA/CD45RO) e da relação entre linfócitos efetores e células reguladoras (CD4/CD25).

Observamos que nenhuma das populações estudadas apresentou variação significativa. Entretanto, há uma tendência à redução do número de células CD4/CD25 positivas no sangue. 


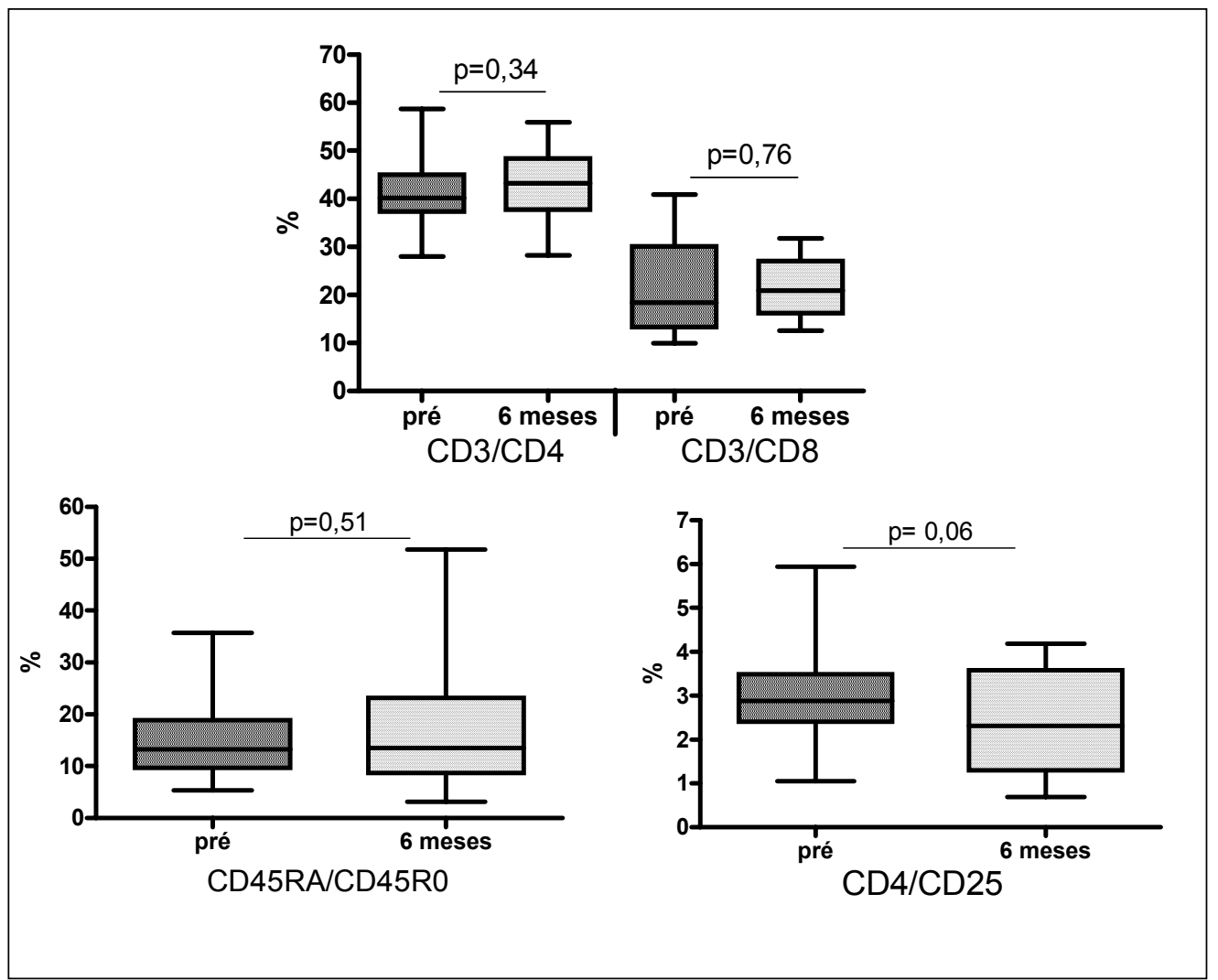

Figura 10A: Expressão em "dot plot" dos marcadores de superfície de populações celulares avaliados por citometria de fluxo no pré-operatório e seis meses após cirurgia. Os dados são representativos da porcentagem da população de linfócitos Th (CD3/CD4) (n=26) e Tc (CD3/CD8) (n=26), da relação entre linfócitos "naïve" e de memória (CD45RA/CD45RO) $(n=24)$ e da relação entre linfócitos efetores e células reguladoras $(C D 4 / C D 25)(n=23)$ medidos em sangue periférico. O teste de Wilcoxon foi aplicado para comparação dos dados nos dois tempos. 

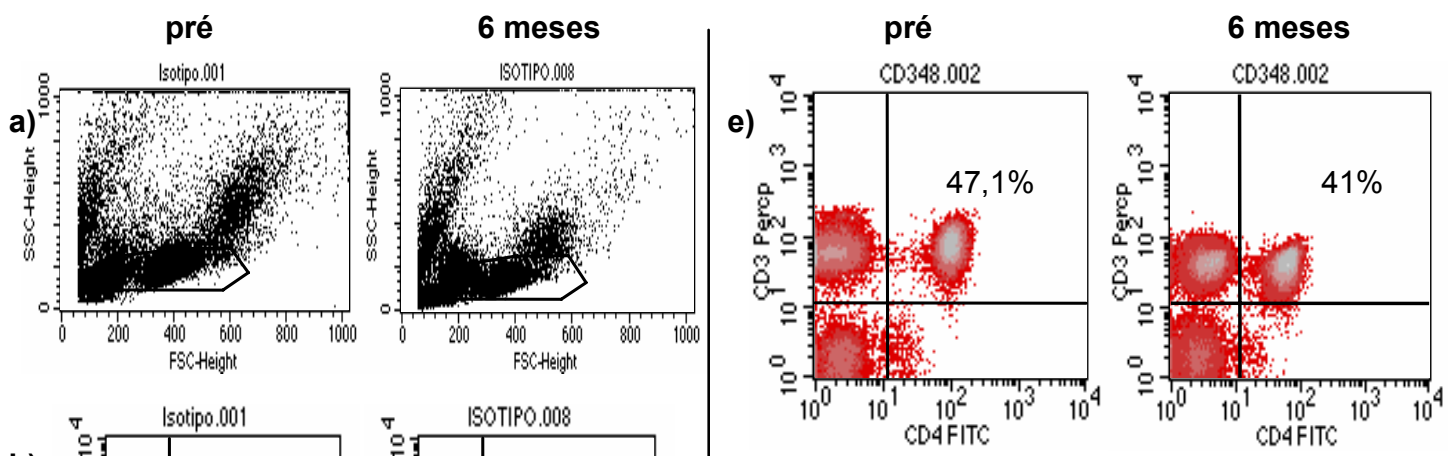

b)

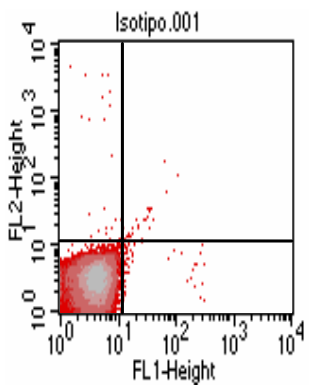

c)

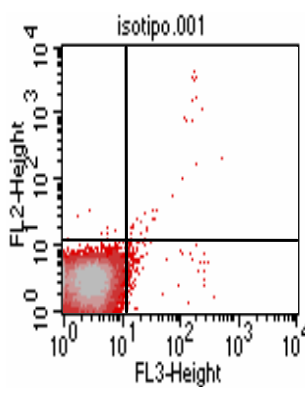

d)

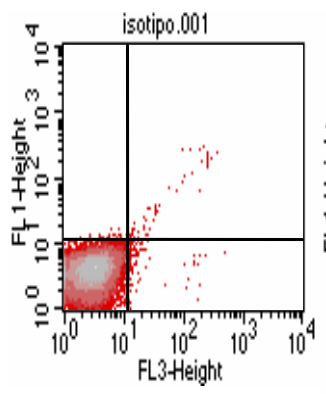

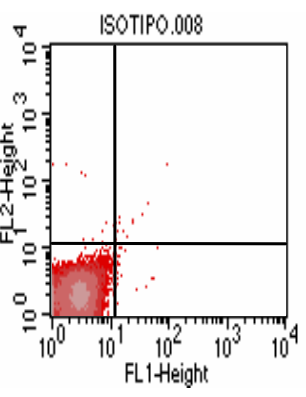
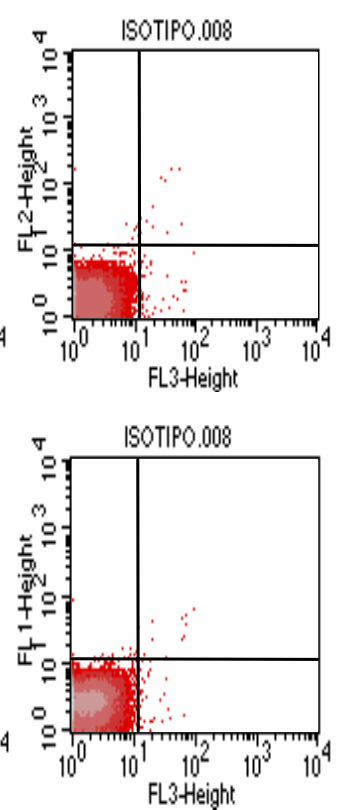
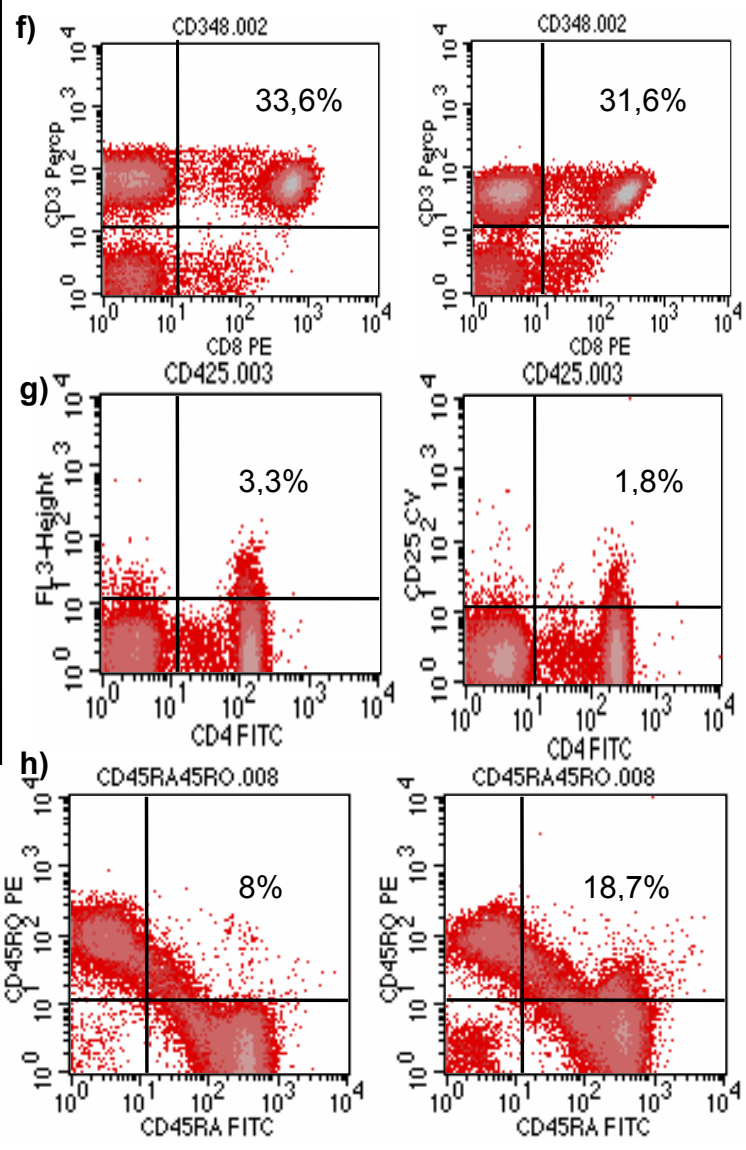

Figura 10B: Exemplo representativo da análise de fenotipagem por citometria de fluxo de células mononucleares de um paciente no pré-operatório e seis meses após a cirurgia. a) Compensação e gating de linfócitos segundo análise de tamanho (FSC) e granulosidade (SSC), utilizados para a aquisição dos dados que foram expressos em porcentagem. b, c e d) controle isotípico. e) células CD3/CD4. f) células CD3/CD8. g) células CD4/CD25. h) células CD45RA/CD45RO. 
Na figura 11 estão representados os gráficos das porcentagens dos marcadores de superfície de células NK (CD56) e de linfócitos B (CD19/CD45) e de ativação precoce de linfócito B (CD19/CD69). Não encontramos diferença entre estas porcentagens após a cirurgia.

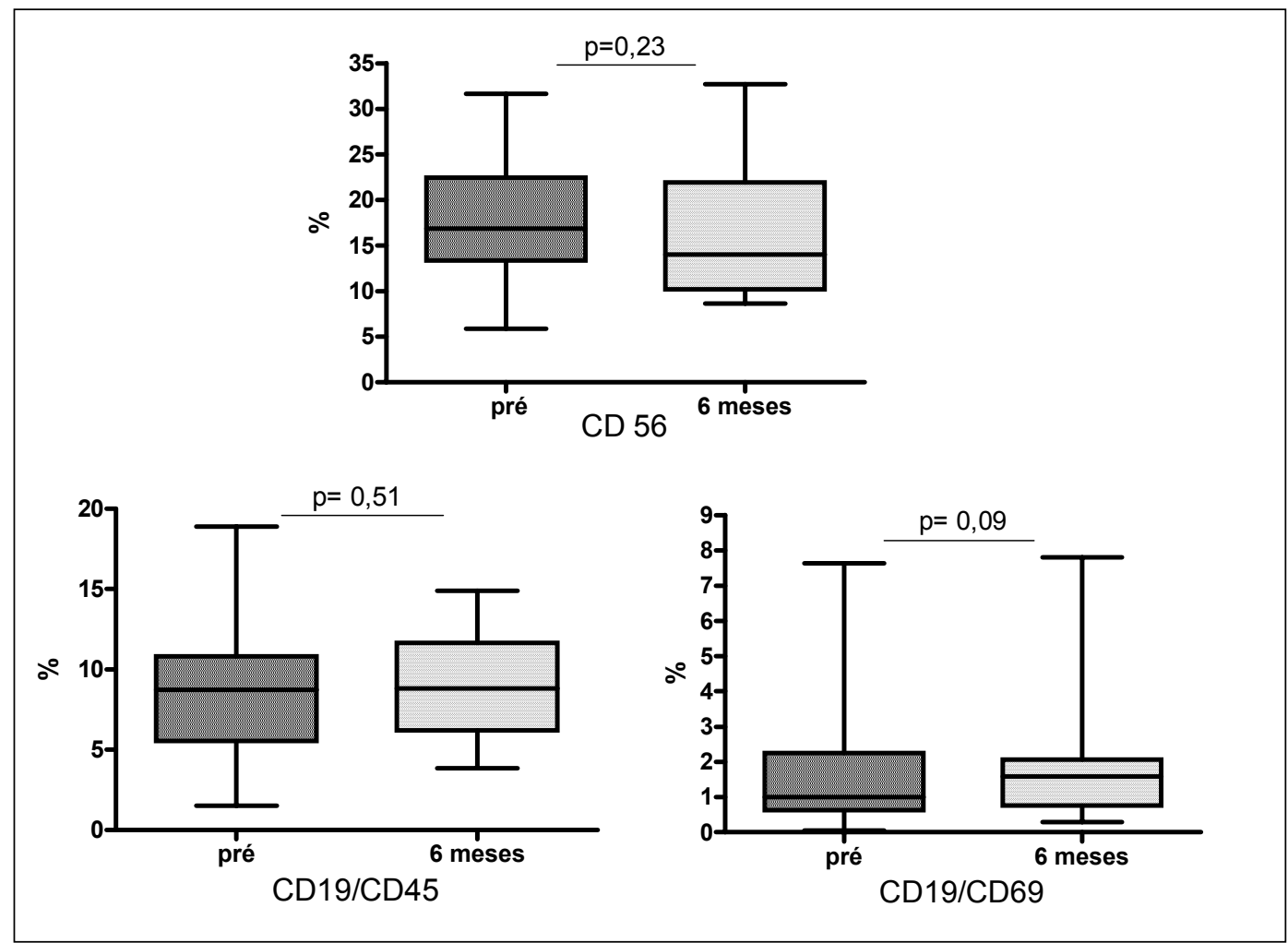

Figura 11A: Expressão em "dot plot" dos marcadores de superfície de outras populações celulares avaliados por citometria de fluxo no pré-operatório e seis meses após cirurgia. Os dados são representativos da porcentagem da população de células NK (CD56) $(n=22)$ e de linfócitos B (CD19/CD45) $(n=25)$ e de ativação precoce de linfócito B (CD19/CD69) $(n=24)$. O teste de Wilcoxon foi aplicado para comparação dos dados nos dois tempos. 
pré

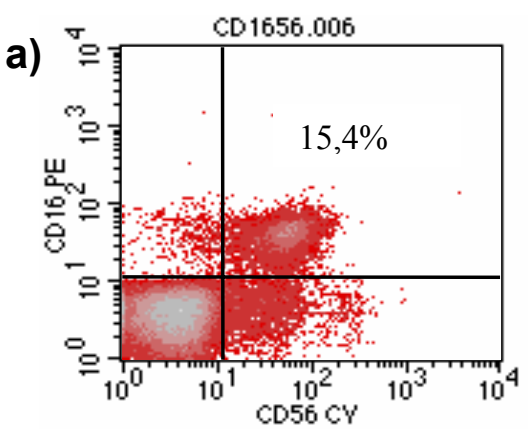

b)
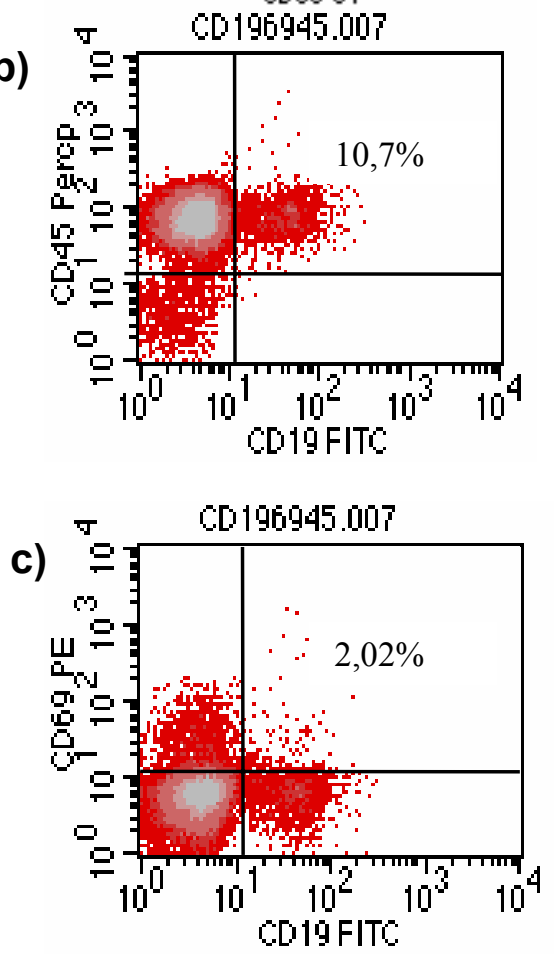

6 meses
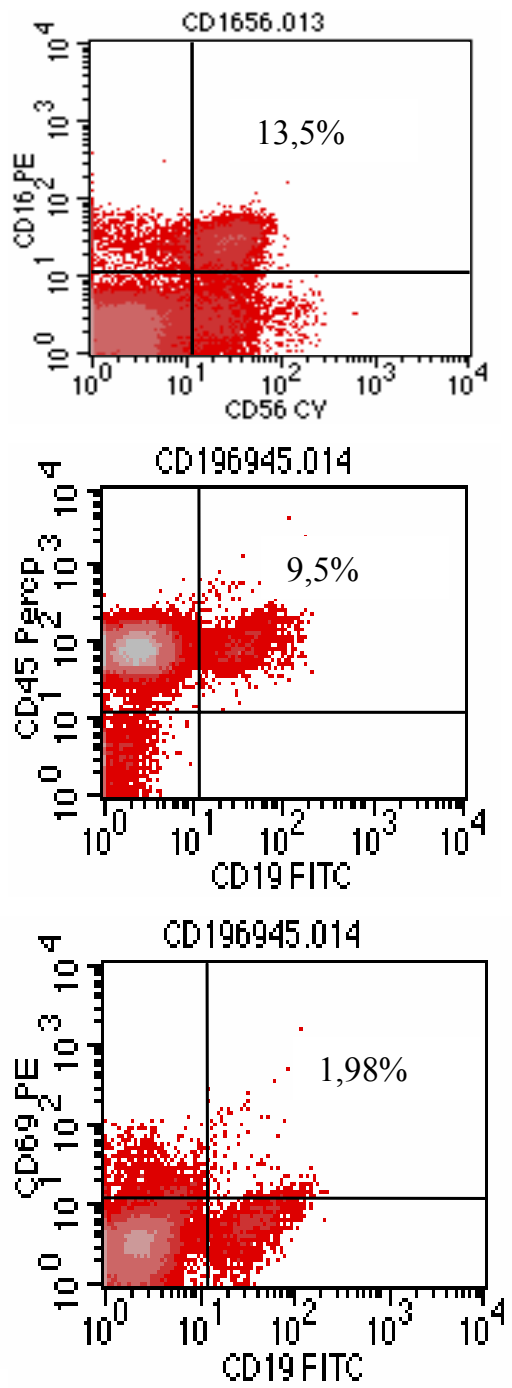

Figura 11B: Exemplo representativo da análise de fenotipagem por citometria de fluxo de células mononucleares de um paciente no pré-operatório e seis meses após a cirurgia. Compensação e gating como na figura 10B. a) células CD56. b) células CD19/CD45. c) células CD19/CD69.

Na figura 12, estão representados os gráficos das porcentagens dos marcadores de superfície associados à ativação celular: os marcadores de linfócitos $T$ ativados (CD4/CD95 e CD8/CD95), de ativação precoce de linfócito B (CD45/CD69) e marcador de linfócito naïve (CD3/CD45RA). Também não encontramos diferença entre estas porcentagens após a cirurgia. 


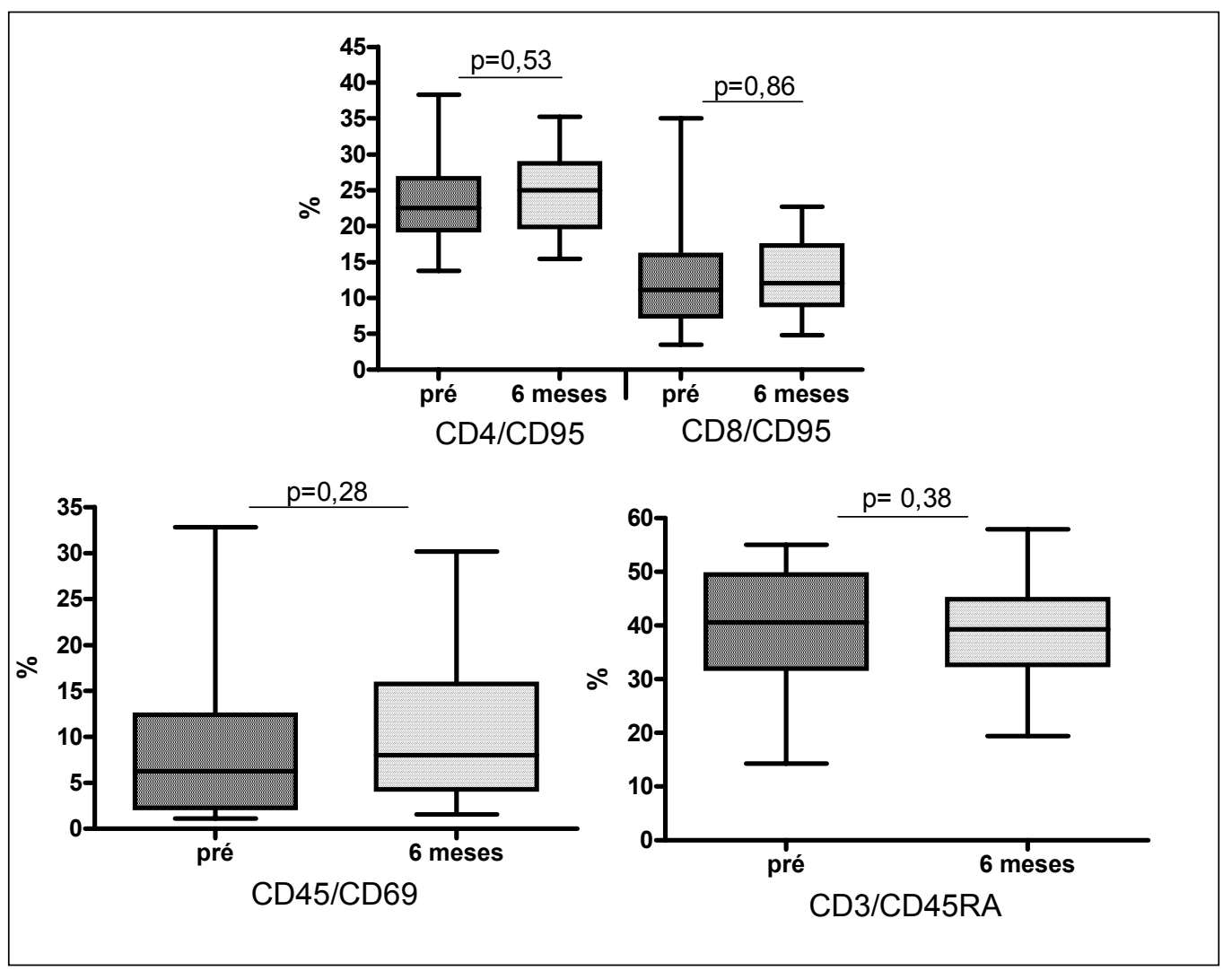

Figura 12A: Expressão em "dot plot" dos marcadores de superfície de ativação avaliados por citometria de fluxo no pré-operatório e seis meses após cirurgia. Os dados são representativos da porcentagem da população dos marcadores de linfócitos $T$ ativados (CD4/CD95 e CD8/CD95) ( $n=24$ e $n=22$, respectivamente), de ativação precoce de linfócito $B(C D 45 / C D 69)(n=23)$ e marcador de linfócito naïve (CD3/CD45RA) ( $n=17)$. O teste de Wilcoxon foi aplicado para comparação dos dados nos dois tempos. 
pré

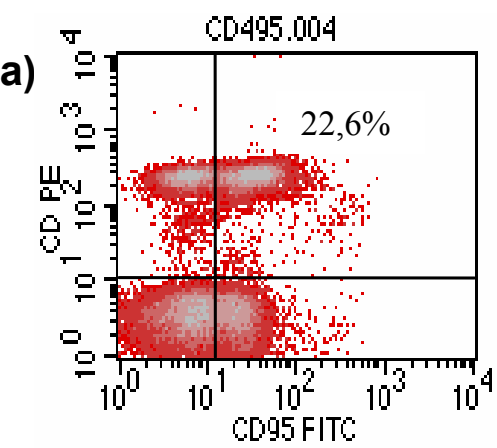

b)

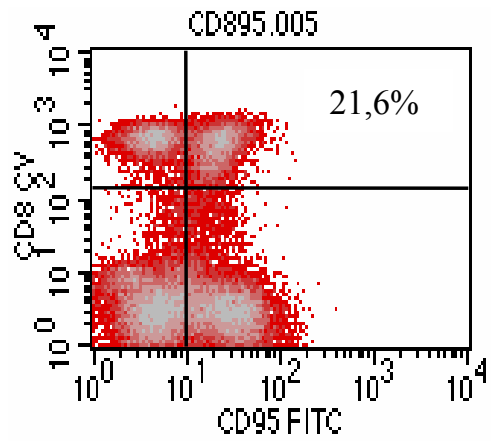

c)

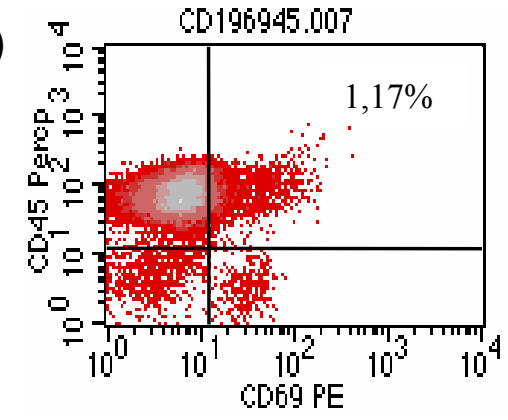

d)

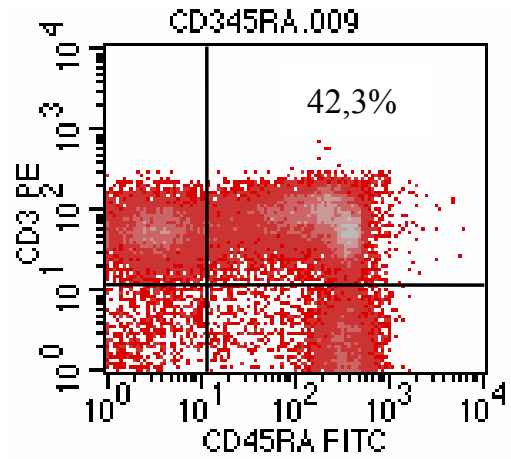

6 meses
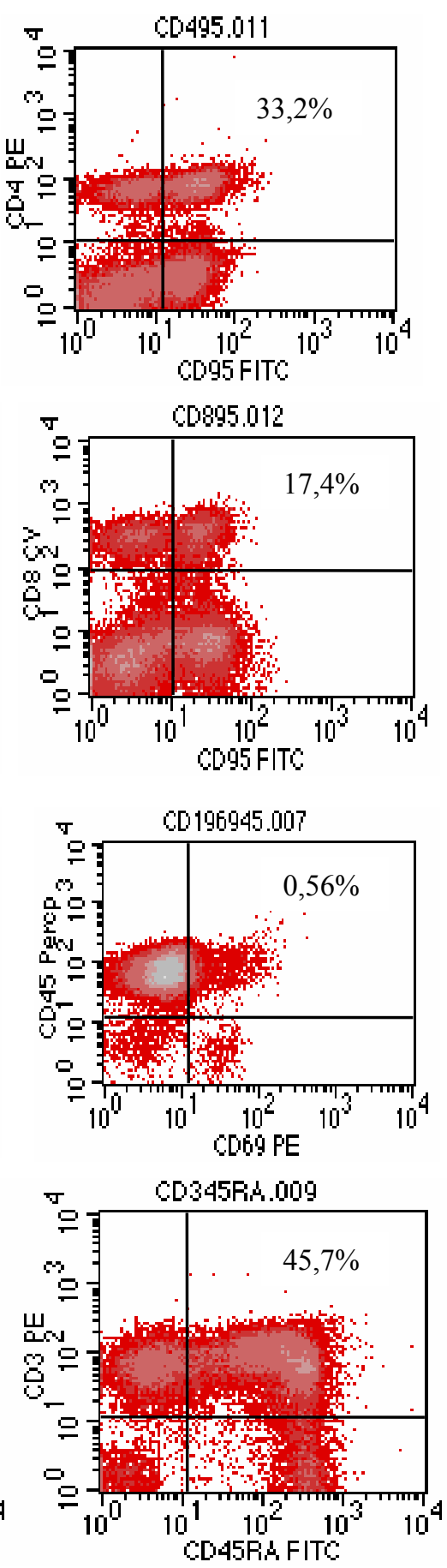

Figura 12B: Exemplo representativo da análise de fenotipagem por citometria de fluxo de células mononucleares de um paciente no pré-operatório e seis meses após a cirurgia. Compensação e gating como na figura 10B. a) células CD4/CD95. b) células CD8/CD95. c) células CD45/CD69. d) células CD3/CD45RA. 


\subsection{4- Atividade citotóxica de células NK}

Observamos aumento significativo na atividade citotóxica das células NK após seis meses da cirurgia. Comparando com os valores de percentual de lise celular obtidos de indivíduos controle, pareados por idade e sexo, de peso normal avaliados no laboratório de Imunologia, notamos que, antes do procedimento, os pacientes apresentavam redução importante da atividade citotóxica destas células. Em seis meses pós-operatório, houve recuperação da atividade citotóxica das células NK. A análise estatística comparando a porcentagem de lise específica na razão células efetoras (células NK): célula alvo (K562) de 40:1 antes e após a cirurgia resultou em uma diferença significativa (Figura 13A).

Pela análise individual dos dados, observamos aumento significativo após a cirurgia em todos os pontos da curva em cerca de $79 \%$ da amostra (22 pacientes). Na figura 13B está o gráfico com a mediana dos pontos da curva de citotoxicidade obtida dos pacientes antes e após a cirurgia e dos indivíduos controle. Notamos aumento significativo nos valores que representam o percentual de lise celular nas proporções células efetoras:células alvo 40:1, 20:1, 10:1 e 5:1. 


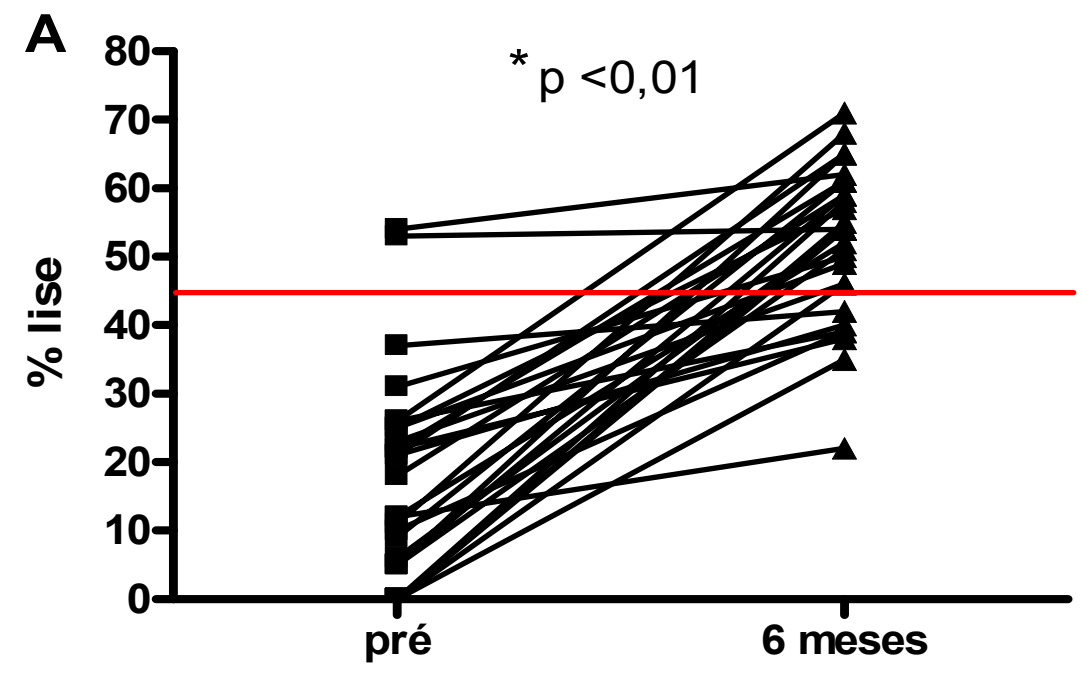

razão células NK: célula K562 = 40:1

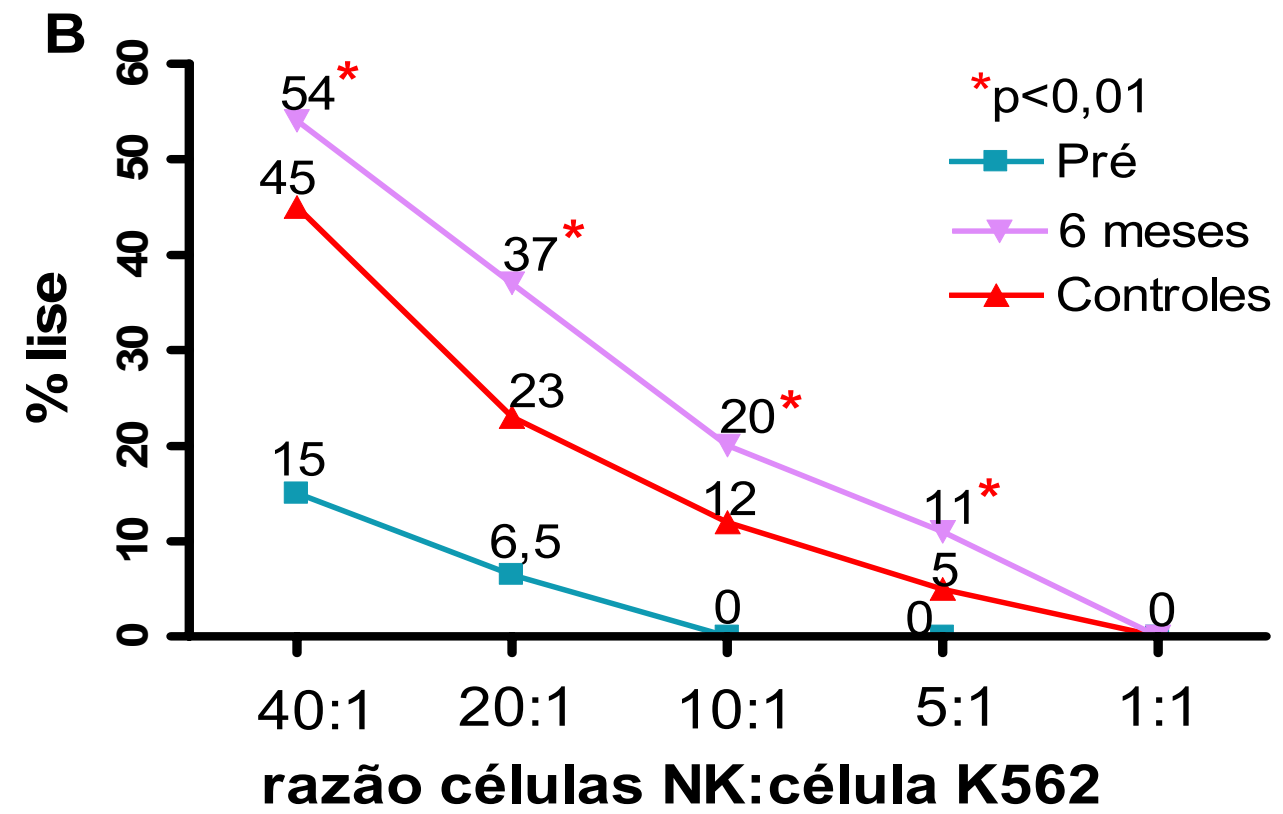

Figura 13: A atividade citotóxica das células NK dos pacientes $(n=28)$ no préoperatório e seis meses após a cirurgia. PBMC foram plaqueadas nas diferentes razões com as células alvo K562 e a citotoxicidade, expressa em porcentagem de lise, foi avaliada através da liberação de LDH, de acordo com Casuística e Métodos. Aumento na resposta citotóxica, seis meses após a cirurgia, na razão células efetoras (células NK):célula alvo (K562) de 40:1 na maioria dos pacientes (A) e em diferentes razões, de 40:1 a 1:1 (B). A linha e a curva vermelhas representam a mediana dos valores obtidos dos controles de peso normal, pareados por idade e sexo, nas respectivas razões. ${ }^{*}$ Teste de Fisher. 
5. DISCUSSÃO 
A obesidade está associada ao comprometimento do sistema imune. Achados clínicos apontam para uma maior susceptibilidade de indivíduos obesos para o desenvolvimento de doenças infecciosas e cânceres. Além disto, uma parte dos pacientes obesos apresenta alterações do metabolismo glicídico e lipídico, as quais também podem comprometer a função de linfócitos e de células NK, já que estas são células de altíssimo metabolismo, com extrema dependência de glicose para geração de energia e para glicosilação de seus receptores de superfície ${ }^{134}$ e que podem sofrer influência de lipoproteínas modificadas para a secreção de fatores vasoativos ${ }^{135}$. Ainda mais, o tecido adiposo, além de ser considerado um grande órgão endócrino, produz substâncias com diversas funções relacionadas ao sistema imune.

Tanto o ganho, como a perda de peso são eventos complexos e seus efeitos sobre a manutenção da homeostase do organismo e sobre a resposta imune podem ser variados e dependentes de diversas combinações possíveis dos múltiplos fatores envolvidos em ambos os processos. Decidimos estudar aspectos da resposta imune de pacientes com obesidade grave antes e após terem sido submetidos a um procedimento cirúrgico reconhecidamente efetivo para promoção de perda de peso significativa, a fim de avaliar o impacto da perda de peso sobre as variáveis analisadas. Em uma tentativa de diminuir as inúmeras interferências associadas com um estudo de parâmetros imunológicos, usamos como critérios de exclusão condições que reconhecidamente modificam a resposta imune, como diabetes mellitus, doenças auto-imunes, neoplasias, infecções crônicas ou uso de imunossupressores. Excluímos também pacientes acima de 60 anos, 
já que a redução da imunidade associada com o envelhecimento é bem documentada. A exclusão dos pacientes que apresentaram complicações graves após a cirurgia também se justificou por ser uma condição de viés na análise dos resultados. Apesar da dislipidemia ser considerada um fator modificador da imunidade, não excluímos pacientes portadores da condição, para que não houvesse restrição excessiva da população estudada, fato que poderia comprometer $\mathrm{o}$ valor de nossos resultados por não refletir a heterogeneidade dos pacientes que são submetidos à cirurgia.

Nosso estudo incluiu pacientes submetidos à cirurgia de DGJYR pela técnica aberta e laparoscópica. McAuliffe et al. ${ }^{123}$ observaram algumas diferenças quando analisaram pacientes submetidos a cada uma das técnicas em relação ao estado de ativação de monócitos e células dendríticas até 28 dias após DGJYR, porém somente quatro pacientes em cada grupo foram incluídos nesta análise. Não mostramos uma subanálise dos resultados nos grupos submetidos às técnicas distintas, já que apenas cinco pacientes realizaram a cirurgia por técnica laparoscópica e estes apresentaram modificações nos parâmetros estudados de forma semelhante aos submetidos à técnica aberta.

O estudo privilegiou a avaliação dos componentes da resposta imune que, pelas características clínicas de pacientes obesos e pelas modificações de estado nutricional geradas após a cirurgia, seriam aqueles mais afetados pelo excesso de peso e, conseqüentemente, por sua perda. Assim, estudamos os marcadores de populações linfocitárias e de células NK e os marcadores de ativação celular CD4/CD95, CD8/CD95, CD45/CD69 e 
CD3/CD45RA. Estudamos também a produção por PBMC das citocinas TNFa, IL-6, IL-2, IFN- $\gamma$ IL-4, IL-10, IL-12 e IL-18, as quais são importantes tanto na imunidade inata como na adaptativa.

Após seis meses da cirurgia, nossos pacientes tiveram uma perda média de $26 \%$ do peso inicial e, como esperado, observamos redução significativa nos níveis glicêmicos e lipídicos. A cirurgia bariátrica tem um reconhecido papel na melhora e reversão de comorbidades associadas com a obesidade. Em uma meta-análise da efetividade do tratamento cirúrgico da obesidade foi descrito que a proporção de pacientes que tinham diabetes no pré-operatório correspondia a cerca de $11 \%$ e que a melhora ou resolução da doença ocorreu em 64 a 100\% dos casos. Neste mesmo trabalho, a prevalência de dislipidemia observada antes da cirurgia foi de $32 \%$ e 60 a $100 \%$ tiveram melhora ou resolução após a cirurgia ${ }^{136}$. As deficiências de ferro e cálcio são frequentemente encontradas após DGJYR. A taxa de incidência de deficiência sérica de ferro observada é até superior a $50 \%$ e pode ocorrer apesar da reposição com polivitamínico ${ }^{137}$. Isto pode justificar a redução nos níveis de ferro observada em nosso estudo. A deficiência de cálcio não é sempre aparente por causa da liberação de cálcio dos ossos ${ }^{137}$. Encontramos um inesperado aumento nos níveis de cálcio iônico após a cirurgia, que pode ser explicado pela baixa variabilidade de valores obtidos, o que tornou o resultado estatisticamente significativo, porém sem relevância clinica. Corroborando a literatura, observamos queda nos níveis circulantes de leptina após a cirurgia. Os estudos sugerem que o IMC é o principal determinante da concentração plasmática de leptina em obesos e que esta 
sempre decresce após a perda de peso, independente do método de tratamento ${ }^{133,138-140}$.

Em relação aos parâmetros imunológicos avaliados após seis meses da cirurgia, não encontramos diferença após a cirurgia em relação aos marcadores de superfície celular (figuras 10 a 12). Observamos apenas uma tendência à queda na população de linfócitos Th ativados (figura 10), que pode ser indicativa de um menor grau de inflamação propiciado pela perda de peso pós-operatória. Cottam et al. ${ }^{65}$ também não observaram modificação nas populações celulares de linfócitos B e T e células NK até um ano após a cirurgia de DGJYR. Por outro lado, neste trabalho foi encontrado, no pósoperatório de um ano, queda no percentual de células T CD95 positivas, marcadoras de apoptose, e de células CD69 positivas, marcadoras de ativação celular precoce. Entretanto, uma comparação mais precisa entre os nossos dados e os deste grupo não foi possível, pois o trabalho citado não apresenta nenhum exemplo de como os parâmetros de compensação, aquisição e "gating" das populações celulares foram feitos e a análise de citometria de fluxo usando coloração fluorescente é dependente destes parâmetros, a qual é influenciada pela interpretação do indivíduo que realiza as medições.

O tecido adiposo é reconhecido como produtor de fatores próinflamatórios, como TNF- $\alpha$ e $\mathrm{IL}-6^{67}$, cujos níveis séricos parecem estar diretamente relacionados com o grau de obesidade ${ }^{142-144}$ e reduzem com a perda de peso ${ }^{118,119,142,143}$. Porém, a produção destas citocinas por células mononucleares em pacientes obesos é descrita em poucos estudos. No 
nosso trabalho, não observamos diferença entre os níveis de TNF- $\alpha$ e IL-6 produzidos em PBMC após estimulação depois de seis meses de cirurgia. O’Rourke et al. ${ }^{145}$ observaram menores níveis transcritos, basais e após estimulação com leptina, de RNA destas citocinas em PBMC em indivíduos obesos que em não obesos. A avaliação de níveis transcritos de RNA de TNF- $\alpha$ compromete a análise, pois esta citocina apresenta também regulação pós-transcripcional de sua produção ${ }^{146}$. Por outro lado, Tanaka et al. ${ }^{59}$ encontraram em pacientes obesos, além de maiores níveis séricos de TNF-a, maior produção em PBMC de TNF- $\alpha$ basal e estimulada por lipopolissacarídeos, quando comparados aos indivíduos não obesos e, após perda de peso induzida por dieta, houve redução da produção estimulada da citocina.

Verificamos um aumento significativo na proliferação de linfócitos estimulada por PHA, o que pode ser interpretado como uma melhora na capacidade dos linfócitos a reagir aos estímulos. O ensaio de proliferação de linfócitos estimulada por mitógenos representa um método simples para a detecção de defeitos em alguns aspectos da função das PBMC e a resposta alterada tem sido associada com uma variedade de deficiências imunes "in vivo"147. Também não identificamos estudos que avaliaram a proliferação de linfócitos estimulada por mitógenos antes e após a cirurgia bariátrica. Restrição energética, com conseqüente perda de peso, em ratos com sobrepeso induzido por dieta aumentou a proliferação de esplenócitos estimulada por mitógenos ${ }^{43}$. De forma semelhante, estudos em pacientes obesos mostraram que a proliferação de linfócitos estimulada por mitógenos 
foi restaurada após perda de peso por dieta ${ }^{58,59}$. Moriguchi et al. ${ }^{88}$ propuseram que a redução da proliferação de linfócitos observada na obesidade pode ser, em parte explicada, pela diminuição da captação de glicose como principal fonte de energia pelos linfócitos no estágio de proliferação. Este grupo mostrou que ratos obesos apresentam redução da expressão do transportador de glicose-1, expresso na membrana das células imunes após estimulação com mitógenos.

Como em seres humanos algumas células NK expressam poucas moléculas CD16 ou não as expressam, preferimos usar somente o marcador CD56 como expressão do número de células com possível atividade citotóxica. Também não foi nosso intuito separar as células NKT das demais, por isto não exploramos a presença de subpopulações CD3 positivas ou negativas. Não encontramos diferença entre o número de células NK seis meses após a cirurgia. Este nosso dado é concordante com o de Cottam et al. ${ }^{65}$, que também não observaram diferença no percentual de células NK circulantes nos tempos 1, 3, 6 e 12 meses após DGJYR.

Quando avaliamos a função de células NK através da citotoxicidade em células alvo K562, medida pela liberação de LDH, observamos que seis meses após a realização da cirurgia, quando os pacientes já estabeleceram um equilíbrio nutricional e perderam significativa quantidade de peso, a grande maioria destes indivíduos apresenta recuperação desta função, que estava diminuída antes da cirurgia. É importante salientar que vários pacientes passaram a apresentar níveis normais de citotoxidade seis meses após a cirurgia (figura 13). Apesar da heterogeneidade do grupo, ao 
incluirmos homens, mulheres antes e após menopausa, além de pacientes com dislipidemia e diferentes técnicas cirúrgicas, a melhora da atividade das células NK ocorreu na grande maioria da amostra, reforçando a perda de peso como fator contribuinte mais notável para a modificação deste parâmetro imunológico.

Há comprometimento da atividade citotóxica de células NK nos pacientes obesos mórbidos que foi demonstrado ao comparamos os resultados obtidos com valores da atividade em indivíduos de peso normal, pareados para idade e sexo (figura 13). Animais com obesidade induzida por dieta apresentam menor atividade citotóxica de células NK, a qual é restaurada por restrição energética ${ }^{43}$. Uma correlação negativa entre atividade citotóxica de células NK e porcentagem de gordura corporal foi observada em mulheres idosas ${ }^{148}$. Em contraste, outros trabalhos não mostraram diferença neste parâmetro entre pacientes obesos e nãoobesos $^{57,149}$. Isto pode ser explicado pelo menor grau de obesidade dos pacientes incluídos nestes últimos estudos. Em nosso estudo, somente pacientes com IMC acima de $40 \mathrm{~kg} / \mathrm{m}^{2}$ foram incluídos.

Como a citotoxicidade foi avaliada utilizando as PBMC totais e não uma seleção de células CD56+, pode-se questionar se nossas dosagens incluíram a morte celular induzida por outras células citotóxicas, especialmente linfócitos Tc. Entretanto, o fato de que as células K562 são MHC I negativas as tornam alvo preferencial das células $\mathrm{NK}$ e, portanto, o impacto da lise induzida por outras células é desprezível ${ }^{150,151}$. 
O mecanismo pelo qual o tecido adiposo direta ou indiretamente controla a função NK não pode ser estabelecido em nosso estudo, entretanto, pudemos demonstrar que ele deva estar associado com a síntese de citocinas fundamentais para o desenvolvimento e a expressão de atividade citotóxica em células NK, a saber, IFN-y, IL-12 e IL-18. Como a proporção de células NK não se alterou após a cirurgia, o aumento nestas citocinas pode explicar a melhora da atividade citotóxica. Observamos que os níveis de produção destas interleucinas, após estimulação com um mitógeno policlonal (PHA), aumentam de forma significativa seis meses após a cirurgia. Este achado é importante pois, junto com a IL-12, a IL-18 é um dos fatores primordiais no desvio da resposta imune para um padrão Th1, isto é, de células T produtoras de IL-2 e IFN- $\gamma$, e que são responsáveis pelo controle do braço celular da resposta imune. Uma diminuição na função Th1 resulta em menores níveis de IL-2 e conseqüentemente uma diminuição de função de células NK e de linfócitos T CD8, fechando assim um ciclo de retroalimentação negativa, que culmina clinicamente com uma diminuição da resposta anti-infecciosa e anti-tumoral. Identificamos somente um trabalho na literatura avaliando o efeito da perda de peso induzida por cirurgia sobre a quantificação de citocinas produzidas diretamente por células imunes. Concordantes com nosso trabalho, como já comentado, Fontana et al. ${ }^{126}$ também observaram aumento da produção de IFN- $\gamma$ um ano após DGJYR.

É bem estabelecida a influência da leptina sobre inúmeras respostas relacionadas à imunidade. Linfócitos T tratados "in vitro" com leptina reagem aumentando a produção de citocinas Th1 IFN- $\gamma$ e IL-2 e reduzindo a 
produção de citocinas Th2 IL- ${ }^{84}$. Observamos que os níveis de leptina caíram e houve aumento de citocinas envolvidas na resposta Th1, o que nos leva a questionar se a leptina poderia ter real influência nos resultados encontrados. Mito et al. ${ }^{152}$ observaram que o jejum com e sem administração de leptina induziu efeito distinto sobre alguns parâmetros imunológicos em ratos com obesidade induzida por dieta e ratos controle. O jejum em ratos controle reduziu o peso de órgãos imunes e a produção de citocinas e aumentou a proliferação estimulada de esplenócitos e estas alterações foram revertidas com a administração de leptina. Por outro lado, ratos com obesidade induzida por dieta não apresentaram alteração nos dois últimos parâmetros citados quando submetidos ao jejum, nem com a administração de leptina e a redução da atrofia tímica induzida por jejum não foi revertida com leptina. Os autores sugerem que as células imunes de ratos com obesidade induzida por dieta apresentam resistência à ação da leptina, já que alguns parâmetros imunes estão reduzidos na obesidade, apesar das altas concentrações de leptina ${ }^{152}$. Um trabalho recente verificou que o efeito estimulador da leptina sobre a atividade de células NK está ausente em ratos com obesidade induzida por dieta. Neste trabalho foi demonstrada uma menor ativação de componentes de sinalização pós-receptor de leptina e foi sugerindo que a alteração na via de ativação mediada por quinase tirosina Janus (JAK)-2 do transdutor de sinal e ativador de transcrição (STAT)-3 é o mecanismo que explica esta resistência à ação da leptina nas células $\mathrm{NK}^{153}$. Outro estudo mostrou que ratos submetidos à dieta rica em gordura exibem supressão da sinalização mediada por STAT-3 do receptor de leptina 
presente em linfócitos $T^{154}$. Portanto, estes trabalhos denotam que resistência à leptina associada à obesidade induzida por dieta pode ocorrer não só em nível hipotalâmico, mas também em células imunes.

Evidências de estudos em animais apontam que dietas ricas em gordura, particularmente gordura saturada, deprime respostas inatas e adquiridas por afetar a atividade de células imunes, como macrófagos, células dendríticas e linfócitos $T^{155}$. Uma redução na ingestão de gordura total na dieta parece aumentar a proliferação de linfócitos a estímulos ${ }^{18} \mathrm{e}$ melhorar a atividade citotóxica de células $\mathrm{NK}^{102}$. Pode ser que, com a redução do consumo total de macronutrientes imposta pela cirurgia, os pacientes tenham reduzido seu consumo proporcional de gordura e que isto seja um fator contribuinte para a melhora encontrada em alguns parâmetros imunológicos. Uma limitação de nosso estudo é a ausência da descrição da composição da dieta dos pacientes. Porém, todos pacientes reduziram sua ingestão calórica. A maioria dos estudos sugere que a restrição calórica melhora alguns parâmetros da resposta imune, como respostas de células T a mitógenos, atividade de células NK e de linfócitos Tc e produção de citocinas por células mononucleares ${ }^{156}$.

Há possibilidade de alteração nutricional induzida pela cirurgia de DGJYR e a influência do estado nutricional sobre a resposta imune é bem caracterizada. Os pacientes receberam orientação nutricional e prescrição de polivitamínico, conforme descrito em Casuística e Métodos, porém sabemos que a ingestão de nutrientes é muito variável. A grande preocupação é que indivíduos que restringem sua ingestão de macronutirentes possam 
apresentar ingestão inadequada de micronutrientes. Realizamos a dosagem de alguns micronutrientes sabidamente envolvidos na resposta imune e encontramos redução apenas nas concentrações de ferro. Pode ser que não tenha ocorrido modificação significativa, pelo fato da restrição energética não ter sido tão longa ou importante para alterar os micronutrientes e tenha sido minimizada pelo uso de polivitamínico.

O trabalho de Albanes $D^{157}$ mostrou que a incidência de tumores espontâneos em ratos é proporcional ao nível de ingestão calórica e ganho de peso resultante, sendo o peso corporal o marcador mais sensível de risco de câncer. Dados de modelos animais demonstram uma menor incidência de câncer associada com restrição calórica, o que corrobora a relação entre regulação do peso e carcinogênese ${ }^{158}$. Obesidade em humanos está associada a maior incidência de vários tipos de câncer, como adenocarcinoma de esôfago, melanoma, leucemia, mieloma múltiplo, linfoma não Hodgkin e cânceres de cólon, tireoíde, endométrio, rim, vesícula, reto, mama e pâncreas ${ }^{159}$. Entre os mecanismos fisiopatológicos propostos para explicar estas evidências epidemiológicas estão a resistência insulínica e a hiperinsulinemia resultante, o aumento da biodisponibilidade de hormônios esteróides e os fatores secretados pelo tecido adiposo que contribuem para a regulação da resposta imune, como leptina, TNF- $\alpha$ e IL-6 $6^{50,51}$. Nossos achados de que a obesidade mórbida leva a uma redução da função das células NK e, sendo estas células de primordial importância na eliminação de células tumorais, nos levam a propor que a baixa atividade citotóxica de 
células NK seja um outro possível mecanismo envolvido na gênese de tumores malignos nestes indivíduos.

Um estudo recente evidenciou que ratos com obesidade induzida por dieta apresentavam maior mortalidade que ratos magros quando infectados com o vírus Influenza, o que foi relacionado com redução na citotoxicidade de células NK e alteração na expressão das citocinas anti-virais IFN- $\alpha$ e IFN$\beta^{160}$. A redução da atividade citotóxica obeservada em nossos pacientes com obesidade mórbida também podem corroborar os estudos clínicos que indicam uma maior incidência de infecção em indivíduos com excesso de peso.

Embora nosso objetivo não tenha sido a avaliação de desfechos clínicos, como presença de tumores malignos e infecções, além do nosso tempo de observação não permitir este tipo de avaliação, é importante ressaltar as evidências descritas na literatura de uma correlação entre baixa atividade citotóxica e maior incidência de tumores e infecções. Portanto, nosso trabalho oferece uma explicação celular para os dados epidemiológicos disponíveis. Além disto, nossos resultados também mostraram que o estado funcional das células NK pode ser recuperado com a perda de peso.

Os mecanismos exatos responsáveis pelas alterações no sistema imunológico em obesos são desconhecidos, mas podem estar relacionados aos efeitos negativos das alterações nutricionais, metabólicas, endócrinas e psicológicas, associadas com a obesidade, sobre a função de células imunes. A perda de peso pode exercer efeito considerável sobre estas 
variáveis. Provavelmente a melhora do ambiente fisiológico contribui para uma melhora da função imune após a perda de peso.

A perda de peso induzida por DGJYR modifica as respostas de algumas citocinas relacionadas com a função das células NK e melhora a sua atividade. A alteração nos níveis de citocinas envolvidas com a atividade das células NK em pacientes obesos mórbidos e a conseqüente alteração da função destas células podem explicar, em parte, a propensão ao desenvolvimento de infecções e cânceres associados com a obesidade. Nossos resultados sugerem que a perda de peso induzida pela cirurgia bariátrica pode ter impacto sobre estes fatores. Estudos a longo prazo, com maior número de pacientes acompanhados após a cirurgia são necessários para confirmar esta hipótese. 
6. CONCLUSÕES 
De acordo com os resultados do presente trabalho, podemos concluir que:

1. A perda de peso induzida por DGJYR aumenta a proliferação de linfócitos T estimulada por mitógeno;

2. A perda de peso induzida por DGJYR aumenta a produção por PBMC de algumas citocinas relacionadas com a função das células NK;

3. A perda de peso induzida por DGJYR restaura a atividade citotóxica de células NK seis meses após a cirurgia. 


\section{ANEXOS}


ANEXO 1.

\section{TERMO DE CONSENTIMENTO LIVRE E ESCLARECIDO}

(Instruções para preenchimento no verso)

\section{I - DADOS DE IDENTIFICAÇÃO DO SUJEITO DA PESQUISA OU RESPONSÁVEL LEGAL}

1. NOME DO PACIENTE .

DOCUMENTO DE IDENTIDADE N ${ }^{\circ}$ SEXO : .M F

DATA NASCIMENTO: .......................

ENDEREÇO

BAIRRO:.

CIDADE

$\mathrm{N}^{\circ}$

APTO:

CEP:

TELEFONE: DDD

2.RESPONSÁVEL LEGAL

NATUREZA (grau de parentesco, tutor, curador etc.)

DOCUMENTO DE IDENTIDADE

SEXO: $M \quad F$

DATA NASCIMENTO.: .....................

ENDEREÇO:

BAIRRO:

$\mathrm{N}^{\circ}$ APTO:

CEP: TELEFONE: DDD CIDADE

\section{II - DADOS SOBRE A PESQUISA CIENTÍFICA}

1. TÍTULO DO PROTOCOLO DE PESQUISA: Avaliação da resposta imune de pacientes obesos mórbidos antes e após cirurgia bariátrica

PESQUISADOR: Cristiane Martins Moulin de Moraes

CARGO/FUNÇÃO: Médica INSCRIÇÃO CONSELHO REGIONAL Nº 113896

UNIDADE DO HCFMUSP: Endocrinologia - Obesidade

3. AVALIAÇÃO DO RISCO DA PESQUISA:

SEM RISCO

$$
\text { RISCO BAIXO }
$$

(probabilidade de que o indivíduo sofra algum dano como consequência imediata ou tardia do estudo)
RISCO MÍNIMO $\mathbf{x}$

RISCO MAIOR
RISCO MÉDIO

4.DURAÇÃO DA PESQUISA : 4 anos 


\section{III - REGISTRO DAS EXPLICAÇÕES DO PESQUISADOR AO PACIENTE OU SEU REPRESENTANTE LEGAL SOBRE A PESQUISA CONSIGNANDO:}

1. justificativa e os objetivos da pesquisa: iremos colher uma amostra do seu sangue para verificar o estado imunológico do seu organismo (ou seja, basicamente, a capacidade de combater infecções), antes da cirurgia e 1 e 6 meses após a mesma.

2. procedimentos que serão utilizados e propósitos, incluindo a identificação dos procedimentos que são experimentais: serão coletados, em jejum, $50 \mathrm{~mL}$ do seu sangue, de onde, além dos testes de imunidade, verificaremos também as taxas de glicose, colesterol, triglicerídeos e de substâncias minerais e vitamínicas.

3. desconfortos e riscos esperados: não há risco neste nosso procedimento; o desconforto está relacionado à coleta de sangue.

4. benefícios que poderão ser obtidos: você poderá ser beneficiado, porque avaliaremos o estado geral de seu organismo e, em particular, sua capacidade de prevenir infecções.

5. procedimentos alternativos que possam ser vantajosos para o indivíduo: se houver alterações, poderemos tratá-las precocemente.

\section{IV - ESCLARECIMENTOS DADOS PELO PESQUISADOR SOBRE GARANTIAS DO SUJEITO DA PESQUISA CONSIGNANDO:}

1. acesso, a qualquer tempo, às informações sobre procedimentos, riscos e benefícios relacionados à pesquisa, inclusive para dirimir eventuais dúvidas: estaremos à sua disposição, a qualquer tempo, para esclarecimentos.

2. liberdade de retirar seu consentimento a qualquer momento e de deixar de participar do estudo, sem que isto traga prejuízo à continuidade da assistência: você tem toda a liberdade de abandonar o estudo e retirar seu consentimento a qualquer momento.

3. salvaguarda da confidencialidade, sigilo e privacidade: todos os dados que forem obtidos de você serão absolutamente confidenciais.

4. disponibilidade de assistência no HCFMUSP, por eventuais danos à saúde, decorrentes da pesquisa: estaremos a sua disposição para qualquer problema que ocorrer decorrente de nosso procedimento; caso haja danos a sua saúde, a Unidade de Obesidade da Disciplina de Endocrinologia e Metabologia da DCM-1 estará disponível para sua assistência.

5. viabilidade de indenização por eventuais danos à saúde decorrentes da pesquisa: não cabe indenização, porque não há possibilidade de ocorrer dados por nosso procedimento. 
V. INFORMAÇÕES DE NOMES, ENDEREÇOS E TELEFONES DOS RESPONSÁVEIS PELO ACOMPANHAMENTO DA PESQUISA, PARA CONTATO EM CASO DE INTERCORRÊNCIAS CLÍNICAS E REAÇÕES ADVERSAS.

Dra Critiane Martins Moulin de Moraes tel: 94274535 ou 30697516

VI. OBSERVAÇÕES COMPLEMENTARES:

\section{VII - CONSENTIMENTO PÓS-ESCLARECIDO}

Declaro que, após convenientemente esclarecido pelo pesquisador e ter entendido o que me foi explicado, consinto em participar do presente Protocolo de Pesquisa

São Paulo,

de

de 
ANEXO 2.

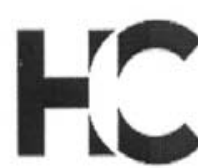

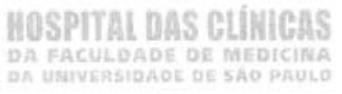

APROVAÇÃO

A Comissão de Ética para Análise de Projetos de Pesquisa - CAPPesq da Diretoria Clínica do Hospital das Clínicas e da Faculdade de Medicina da Universidade de São Paulo, em sessão de 13.10.04, APROVOU o Protocolo de Pesquisa $n^{\circ} 795 / 04$, intitulado: "Avaliação da resposta imune de pacientes obesos mórbidos antes e após cirurgia bariátrica" apresentado pelo Departamento de CLÍNICA MÉDICA, inclusive o Termo de Consentimento Livre e Esclarecido.

Pesquisador(a) Responsável: Prof. Dr. Alfredo Halpern Pesquisador(a) Executante: Dra. Cristiane Martins Moulin de Moraes CAPPesq, 13 de Outubro de 2004.

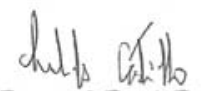

PROF. DR. EUCLIDES AYRES DE CASTILHO Presidente da Comissão de Ética para Análise de Projetos de Pesquisa

OBSERVAÇÃO: Cabe ao pesquisador elaborar e apresentar à CAPPesq, os relatórios parciais e final sobre a pesquisa (Resolução do Conselho Nacional de Saúde $n^{\circ} 196$, de 10.10.1996, inciso IX.2, letra "c")

Comissõo de Ética para Análise de Projetos de Pesquisa do HCFMUSP e da FMUSP Diretoria Clínica do Hospital das Clínicas da Faculdade de Medicina da Universidade de Sð̃o Paulo Rua Ovídio Pires de Campos, 255, $5^{\circ}$ andar - CEP 05430010 - São Paulo - SP Fone: 011 - 30696442 fax : 011 - 30696492 - e-mail : cappesq@henet.usp.br / secretoriocoppesq@hcnet.usp.br 
8. REFERÊNCIAS BIBLIOGRÁFICAS 
1. AACE/ACE Obesity Task Force. AACE/ACE position statement on the prevention, diagnosis, and treatment of obesity (1998 Revision). Endocr Pract 1998; 4: 297-350.

2. Ogden CL, Carroll MD, Curtin LR, McDowell MA, Tabak CJ, Flegal KM. Prevalence of overweight and obesity in the United States, 19992004. JAMA 2006; 295: 1549-55.

3. Sichieri R, Coitinho DC, Leão MM, Recine E, Everhart JE. High temporal, geographic, and income variation in body mass index among adults in Brazil. Am J Public Health 1994; 84: 793-8.

4. Monteiro CA, D’A Benicio MH, Conde WL, Popkin BM. Shifting obesity trends in Brazil. Eur J Clin Nutr 2000; 54: 342-6.

5. Pesquisa de Orçamentos Familiares 2002-2003: análise da disponibilidade domiciliar de alimentos e do estado nutricional no Brasil. IBGE (Instituto Brasileiro de Geografia e Estatística), 2004.

6. Berti LV. Obesidade em notícia [citado 17 de janeiro de 2008]. Disponível em: http://www.abeso.org.br/reportagens/pesquisa pop brasi obesidade morbida.htm.

7. WHO Consultation on Obesity. Obesity: preventing and managing the global epidemic. WHO Tech Rep Series n 894. Geneva, Switzerland: World Health Organization, 2000.

8. Wolf AM, Colditz GA. Current estimates of the economic cost of obesity in the United States. Obes Res 1998; 6: 97-106. 
9. Arterburn DE, Maciejewski ML, Tsevat J. Impact of morbid obesity on medical expenditures in adults. Int J Obes 2005; 29: 334-9.

10. Flegal KM, Graubard BI, Williamson DF, Gail MH. Excess deaths associated with underweight, overweight, and obesity. JAMA 2005; 293: 1861-7.

11. Abbas AK, Lichtmann AH, Pober JS. Imunologia Celular e Molecular. $4^{\mathrm{a}}$ edição. Livraria e Editora Revinter Ltda; 2003.

12. Janeway CA, Travers $P$, Walport M, Sholmchik MJ. Immunobiology: The Immune System in Health and Disease. $6^{\text {th }}$ edition. Garland Science Publishing Inc.: New York; 2005.

13. Galli SJ, Kalesnikoff J, Grimbaldeston MA, Piliponsky AM, Williams CMM, Tsai Mast cells as "tunable " effector and immunoregulatory cells: recent advances. Ann Rev Immunol 2005; 23: 749-86.

14. Abbas AK, Janeway CA. Immunology: improving on nature in the twenty-first century. Cell 2000; 100: 129-38.

15. Vivier E, Malissen B. Innate and adaptive immunity: specificities and signaling hierarchies revisited. Nat Immunol 2005; 6: 17-21.

16. Medzhitov R, Janeway CA. Innate immune recognition and control of adaptive immune responses. Semin Immunol 1998; 10: 351-3.

17. Drayton DL, Liao S, Mounzer RH, Ruddle NH. Lymphoid organ development: from ontogeny to neogenesis. Nat Immunol 2006; 7: 344-53.

18. Calder PC, Yaqoob P, Thies F, Wallace FA, Miles EA. Fatty acids and lymphocyte functions. Br J Nutr 2002; 87 Suppl 1: S31-48. 
19. Medzhitov R, Janeway CA. Innate immunity: impact on adaptive immune response. Cur Opin Immunol 1997; 9: 4-9.

20. Wood PR, Seow H-F. T cell cytokines and disease prevention. Vet Immunol Immunopat 1996; 54: 33-44.

21. Hallett WHD, Murphy WJ. Positive and negative regulation of natural killer cells: therapeutic implications. Seminars Canc Biol 2006; 16: 36782.

22. Schroder K, Hertzog PJ, Ravasi T, Hume DA. Interferon-gamma: an overview of signals, mechanisms and functions. J Leukoc Biol 2004; 75: 163-89.

23. Arai K, Lee F, Miyajima A, Miyatake S, Arai N, Yokota T. Cytokines: coordinators of immune and inflammatory responses. Annu Rev Biochem 1990; 59: 783-836.

24. Mocelin S, Panelli MC, Wang E, Nagorsen D, Marincola FM. The dual role of IL-10. Trends Immnol 2003, 24: 36-43.

25. Trinchieri G. Cytokines and cytokines receptors. Immunol Rev 2004; 2002: 5-7.

26. Wynn TA. IL-13 effector functions. Annu Rev Immunol 2003; 21: 42556.

27. Workshop I: development and differentiation of immune system: I.2I.29. Immunobiol 2003; 208: 94-104.

28. Watford WT, Moriguchi M, Morinobu A, O'Shea JJ. The biology of IL12: coordinating innate and adaptive immune responses. Cytok Growth Fact Rev 2003; 14: 361-8. 
29. Reddy P. Interleukin-18: recent advances. Curr Opin Hematol 2004; 11: 405-10.

30. Nakanishi K, Yoshimoto T, Tsutsui H, Okamura H. Interleukin-18 regulates both Th1 and Th2 responses. Annu Rev Immunol 2001; 19: 423-74.

31. Orange JS, Ballas ZK. Natural killer cells in human health and disease. Clin Immunol 2006; 118: 1-10.

32. Raulet $\mathrm{DH}$. Interplay of natural killer cells and their receptors with the adaptive immune response. Nat Immunol 2004; 5: 996-1002.

33. Biron CA, Nguyen KB, Pien GC, Cousens LP, Salazar-Mather TP. Natural killer cells in antiviral defense: function and regulation by innate cytokines. Annu Rev Immunol 1999; 17: 189-220.

34. Cerwenka H, Wolf G, Mischinger HJ, Cerwenka A, Demel U, Tilz GP. Natural killer cell deficiency and severe wound infection after thyroid surgery. Eur J Surg 2001; 167: 792-4.

35. Whiteside TL, Herberman RB. Role of human natural killer cells in health and disease. Clin Diagn Lab Immunol 1994; 1: 125-33.

36. Ogata K, An E, Shioi Y, Nakamura K, Luo S, Yokose N, Minami S, Dan K. Association between natural killer cell activity and infection in immunologically normal elderly people. Clin Exp Immunol 2001; 124 : $392-7$.

37. Nagatomi R. The implication of alterations in leukocyte subset counts on immune function. Exerc Immunol Rev 2006; 12: 54-71. 
38. Imai K, Matsuyama S, Miyake S, Suga K, Nakachi K. Natural cytotoxic activity of peripheral-blood lymphocytes and cancer incidence: an 11year follow-up study of a general population. Lancet 2000; 356: 17959.

39. Ghiringhelli F, Ménard C, Martin F, Zitvogel L. The role of regulatory $T$ cells in the control of natural killer cells: relevance during tumor progression. Immunol Rev 2006; 214: 229-38.

40. Martí A, Marcos A, Martínez JA. Obesity and immune function relationships. Obes Rev 2001; 2: 131-40.

41. Sedletskii lul, Mirchuk KK, Koreshkin IA. The immune status of patients with obesity. Vrachebnoe Delo 1990; 9: 71-3.

42. Lamas O, Martinez JA, Marti A. T helper lymphopenia and decreased mitogenic response in cafeteria diet-induced obese rats. Nutr Res 2002; 22: 496-507.

43. Lamas O, Martinez JA, Marti. Energy restriction restores the impaired immune response in overweight (cafeteria) rats. J Nutr Biochem 2004; 15: 418-25.

44. Katagiri K, Arakawa S, Kurahashi R, Hatano Y. Impaired contact hypersensitivity in diet-induced obese mice. J Dermatol Sci 2007; 46: 117-26.

45. Gottschlich MM, Mayes T, Khoury JC, Warden GD. Significance on nutritional, immunologic, hormonal, and clinical outcome parameters in burns. J Am Diet Assoc 1993; 93: 1261-8. 
46. Cantürk Z, Cantürk NZ, Cetinarslan B, Utkan NZ, Tankun I. Nosocomial infections and obesity in surgical patients. Obes Surg 1999; 9: 229-34.

47. Bamgbade OA, Rutter TW, Nafiu OO, Dorie P. Postperative complications in obese and nonobese patients. World J Surg 2007; 31: 556-60.

48. Fasol R, Schindler M, Schumacher B, Schlaudraff K, Hannes W, Seitelberger R, Schlosser V. The influence of obesity on perioperative morbidity: restropective study of 502 aortocoronary bypass operations. J Thorac Cardiovasc Surg 1992; 40: 126-9.

49. Weber DJ, Rutala WA, Samsa GP, Santimaw JE, Lemon SM. Obesity as a predictor of poor antibody response to hepatitis B plasma vaccine. JAMA 1985; 254: 3187-9.

50. Calle EE, Kaaks R. Overweight, obesity and cancer: epidemiological evidence and proposed mechanisms. Nat Rev Cancer 2004; 4: 57991.

51. Ceschi M, Gutzwiller F, Moch H, Eichholzer M, Probst-Hensch NM. Epidemiology and pathophysiology of obesity as cause of cancer. Swiss Med Wkly 2007; 137: 50-6.

52. Kim R, Emi M, Tanabe K. Cancer immunoediting from immune surveillance to imune escape. Immunology 2007; 121: 1-14.

53. Hussain SP, Hofseth LJ, Harris CC. Radical causes of cancer. Nat Rev Cancer 2003; 3: 276-85. 
54. Kaaks R, Lukanova A. Energy balance and cancer: the role of insulin and insulin-like growth factor-I. Proc Nutr Soc 2001; 60: 91-106.

55. Nieto FJ, Szklo M, Folsom AR, Rock R, Mercuri M. Leukocyte count correlates in midlle-aged adults: the Atherosclerosis Risk in Communities (ARIC) Study. Am J Epidemiol 1992; 136: 525-37.

56. Nieman DC, Nehlsen-Cannarella SL, Henson DA, Butterworth DE, Fagoaga OR, Warren BJ, Rainwater MK. Immune response to obesity and moderate weight loss. Int J Obes 1996; 29: 353-60.

57. Nieman DC, Henson DA, Nehlsen-Cannarella SL, Ekkens M, Utter AC, Butterworth DE, Fagoaga OR. Influence of obesity on immune function. J Am Diet Assoc 1999; 99: 294-9.

58. Tanaka S, Inoue S, Isoda F, Waseda M, Ishihara M, Yamakawa T, Sugiyama A, Takamura Y, Okuda K. Impaired immunity in obesity: suppressed but reversible lymphocyte responsiveness. Int J Obes 1993; 17: 631-6.

59. Tanaka S, Isoda F, Ishihara $\mathrm{Y}$, Kimura M, Yamakawa T. T lymphopaenia in relation to body mass index and TNF- $\alpha$ in human obesity: adequate weight reduction can be corrective. Clin Endocrinol $2001 ; 54: 347-54$.

60. Chandra RK, Kutty KM. Immunocompetence in obesity. Acta Paediatr Scand 1980; 69: 25-30.

61. Krishnan EC, Trost L, Aarons S, Jewell WR. Study of function and maturation of monocytes in morbidly obese individuals. J Surg Res 1982; 33: 89-97. 
62. Palmblad J, Hallberg D, Engsted L. Polymorphonuclear (PMN) function after small intestinal shunt operation for morbid obesity. $\mathrm{Br} \mathrm{J}$ Haematol 1980; 44: 101-8.

63. Adami GF, Grffanti Bártoli F, Traverso E, Scopinaro N. Evaluation in vivo, with delayed hypersensitivity skin tests, of cell mediated immunity in patients with severe obesity. Minerva Medica 1980; 71: 1769-72.

64. Cottam DR, Schaefer PA, Shaftan GW, Velcu L, Angus LD. Effect of surgically-induced weight loss on leukocyte indicators of chronic inflammation in morbid obesity. Obes Surg 2002; 12: 335-42.

65. Cottam DR, Schaefer PA, Shaftan GW, Angus LD. Dysfunctional immune-privilege in morbid obesity: implications and effect of gastric bypass surgery. Obes Surg 2003; 13: 49-57.

66. Fhühbeck G, Gómez-Ambrosi J, Muruzábal FJ, Burrell MA. The adipocyte: a model for integration of endocrine and metabolic signaling in energy metabolism regulation. Am J Physiol Endocrinol Metab 2001; 280: E827-47.

67. Lyon CJ, Law RE, Hsueh WA. Minireview: adiposity, inflammation, and atherogenesis. Endocrinology 2003; 144: 2195-200.

68. Cousin B, Munoz O, Andre M, Fontanilles AM, Dani C, Cousin JL, Laharrague $\mathrm{P}$, Casteilla $\mathrm{L}$, Pénicaud L. A role for preadipocytes as macrophage-like cells. FASEB J 1999; 14: 305-12.

69. Weisberg SP, McCann D, Desai M, Rosenbaum M, Leibel RL, Ferrante Jr AW. Obesity is associated with macrophage accumulation in adipose tissue. J Clin Invest 2003; 112: 1796-808. 
70. Yudkin JS, Kumari M, Humphries SE, Mohamed-Ali V. Inflammation, obesity, stress and coronary heart disease: is interleukin- 6 the link? Atherosclerosis 2000; 148: 209-214.

71. Hotamisligil GS, Shargill NS, Spiegelman BM. Adipose expression of tumor necrosis factor- $\alpha$ : direct role in obesity-linked insulin resistance. Science 1993; 259: 87-91.

72. Choy LN, Spiegelman BM. Regulation of alternative pathway activation and C3a production by adipose cells. Obes Res 1996; 4: 521-32.

73. Cianflone K. Acylation stimulating protein and the adipocyte. J Endocrinol 1997; 155: 203-6.

74. Considine RV, Sinha MK, Heiman ML, Kriauciunas A, Stephens TW, Nyce MR, Ohannesian JP, Marco CC, McKee LJ, Bauer TL, Caro JF. Serum immunoreactive-leptin concentrations in normal-weight and obese humans. N Engl J Med 1996; 334: 292-5.

75. Faggioni $\mathrm{R}$, Feingold $\mathrm{KR}$, Grunfeld $\mathrm{C}$. Leptin regulation of the immune response and the immunodeficiency of malnutrition. FASEB J 2001; 15: $2565-71$.

76. Wauters $M$, Considine RV, Van Gaal LF. Human leptin: from an adipocyte hormone to an endocrine mediator. Eur J Endocrinol 2000; 143: 293-311.

77. Matarese G, Moschos S, Mantzoros CS. Leptin in immunology. J Immunol 2005; 173: 3137-42.

78. Mikhail AA, Beck EX, Shafer A, Barut B, Gbur JS, Zupancic TJ, Schweitzer AC, Cioffi JA, Lacaud G, Ouyang B, Keller G, Snodgrass 
HR. Leptin stimulates fetal and adult erythroid and myeloid development. Blood 1997; 89: 1507-12.

79. Santos-Alvarez J, Goberna R, Sanchez-Margalet V. Human leptin stimulates proliferation and activation of human circulating monocytes. Cell Immunol 1999; 194: 6-11.

80. Loffreda S, Yang SQ, Lin HZ, Karp CL, Brengman ML, Wang DJ, Klein AS, Bulkley GB, Bao C, Noble PW, Lane MD, Diehl AM. Leptin regulates proinflammatory immune responses. FASEB J 1998; 12: 5765.

81. Sanchez-Margalet V, Martin-Romero C, Santos-Alvarez J, Goberna R, Najib S, Gonzalez-Yanes C. Role of leptin as an immunomodulator of blood mononuclear cells: mechanisms of action. Clin Exp Immunol 2003; 133: 11-9.

82. Mattioli B, Straface E, Quaranta MG, Giordani L, Viora M. Leptin promotes differentiation and survival of human dendritic cells and licenses them for Th1 priming. $\mathrm{J}$ Immunol 2005; 174: 6820-8.

83. Zhao Y, Sun R, You L, Gao C, Tian Z. Expression of leptin receptors and response to leptin stimulation of human natural killer cell lines. Biochem Biophys Res Commun 2003; 300: 247-52.

84. Lord GM, Matarese G, Howard JK, Baker RJ, Bloom SR, Lechler RI. Leptin modulates the T-cell immune response and reverses starvationinduced immunosuppression. Nature 1998; 394: 897-901. 
85. Martin-Romero C, Santos-Alvarez J, Goberna R, Sanchez-Margalet V. Human leptin enhances activation and proliferation of human circulating T lymphocytes. Cell Immunol 2000; 199: 15-24.

86. Chan JL, Matarese G, Shetty GK, Raciti P, Kelesidis I, Aufiero D, De Rosa V, Perna F, Fontana S, Mantzoros CS. Differential regulation of metabolic, neuroendocrine, and immune function by leptin in humans. PNAS 2006; 103: 8481-6.

87. Tanaka S, Isoda F, Yamakawa T, Ishihara M, Sekihara H. T lymphopenia in genetically obese rats. Clin Immunol Immunopathol 1998; 86: 219-225.

88. Moriguchi S, Kato M, Sakai K, Yamamoto S, Shimizu E. Decreased mitogen response of splenic lymphocytes in obese Zucker rats is associated with the decreased expression of glucose transporter 1 (GLUT-1). Am J Clin Nutr 1998; 67: 1124-9.

89. Chandra RK. Cell-mediated immunity in genetically obese (C57BL/6J ob/ob) mice. Am J Clin Nutr 1980; 33: 13-6.

90. Hick RW, Gruver AL, Ventevogel MS, Haynes BF, Sempowski GD. Leptin selectively augments thymopoiesis in leptin deficiency and lipopolysaccharide-induced thymic atrophy. J Immunol 2006; 177: 16976.

91. Macia L, Delacre M, Abboud G, Ouk TS, Delanoye A, Verwaerde C, Saule P, Wolowezuk I. Impairment of dendritic cell functionality and steady-state number in obese mice. J Immunol 2006; 177: 5997-6006. 
92. Faggioni R, Moser A, Feingold KR, Grunfeld C. Reduced leptin levels in starvation increase susceptibility to endotoxic shock. Am J Pathol 2000; 156: 1781-7.

93. Takahashi N, Waelput W, Guisez Y. Leptin is an endogenous protective protein against the toxicity exerted by tumor necrosis factor. J Exp Med 1999; 189: 207-12.

94. Ozata M, Ozdemir IC, Licinio J. Human leptin deficiency caused by a missense mutation: multiple endocrine defects, decreased sympathetic tone, and immune system dysfunction indicate new targets for leptin action, greater central than peripheral resistance to the effects of leptin, and spontaneous correction of leptin-mediated defects. J Clin Endocrinol Metab 1999; 84: 3686-95.

95. Farooqi IS, Matarese G, Lord GM, Keogh JM, Lawrence E, Agwu C, Sanna V, Jebb SA, Perna F, Fontana S, Lechler RI, DePaoli AM, O'Rahilly S. Beneficial effects of leptin on obesity, $T$ cell hyporesponsiveness, and neuroendocrine/metabolic dysfunction of human congenital leptin deficiency. J Clin Invest 2002; 110: 1093-103.

96. Chandra RK. Nutrition and the immune system: an introduction. Am J Clin Nutr 1997; 66 (suppl): 460S-3S.

97. Field CJ. Use of $T$ cell function to determine the effect of physiologically active food components. Am J Clin Nutr 2000; 71 (suppl): 1720S-5S. 
98. Cunningham-Rundles S, McNeeley DF, Moon A. Mechanisms of nutrient modulation of the immune response. J Allergy Clin Immunol 2005; 115: 1119-28.

99. Stallone DD. The influence of obesity and its treatment on the immune system. Nutr Rev 1994; 52: 37-50.

100. de Pablo MA, Alvarez de Cienfuegos G. Modulatory effects of dietary lipids on immune system functions. Immunol Cell Biol 2000; 78: 31-9.

101. Verwaerde C, Delanoye A, Macia L, Tailleux A, Wolowczuk I. Influence of high-fat feeding on both naive and antigen-experienced T-cell immune response in D010.11 mice. Scand J Immunol 2006; 64: 45766.

102. Barone J, Hebert JR, Reddy MM. Dietary fat and natural-killer-cell activity. Am J Clin Nutr 1989; 50: 861-7.

103. Miller WC, Lindeman AK, Wallace J, Niederpruem M. Diet composition, energy intake and exercise in relation to body fat in men and women. Am J Clin Nutr 1990; 52: 426-30.

104. Wing EJ, Stanko RT, Winkelstein A, Adibi SA. Fasting-enhanced immune effector mechanisms in obese subjects. Am J Med 1983; 75: 91-6.

105. McMurray RW, Bradsher RW, Steele RW, Pilkington NS. Effect of prolonged modified fasting in obese persons on in vitro markers of immunity: lymphocyte function and serum effects on normal neutrophils. Am J Med Sci 1990; 299: 379-85. 
106. Kelley DS, Daudu PA, Branch LB, Johnson HL, Taylor PC, Mackey B. Energy restriction decreases number of circulating natural killer and serum levels of immunoglobulins in overweight women. Eur $\mathrm{J}$ Clin Nutr 1994; 48: 9-18.

107. Scanga CB, Verde TJ, Paolone AM, Andersen RE, Wadden TA. Effects of weight loss and exercise training on natural killer cell activity in obese women. Med Sci Sports Exerc 1998; 30: 1666-71.

108. Field CJ, Gougeon R, Marliss EB. Changes in circulating leukocytes and mitogen responses during very-low-energy all-protein reducing diets. Am J Clin Nutr 1991; 54: 123-9.

109. Choban PS, Jackson B, Poplawski S, Bistolarides P. Bariatric surgery for morbid obesity: why, who, when, how, where, and then what? Cleve Clin J Med 2002; 69: 897-903.

110. Herron DM. The surgical management of severe obesity. The Mount Sinai J Med 2004; 71: 63-71.

111. Griffen WO, Bivins BA, Bell RM. The decline and fall of the jejunoileal bypass. Surg Gynecol Obstet 1983; 157: 301-8.

112. Hallberg D, Nilsson BS, Backman L. Immunologic function in patients operated on with small intestinal shunts for morbid obesity. Scand $\mathrm{J}$ Gastroenterol 1976; 11: 41-8.

113. Tustin AW, Kaiser AB, Bradsher RW, Herrington JL. Unusual fungal infections following jejunoileal bypass surgery. Arch Intern Med 1980; 140: 643-5. 
114. Adami GF, Civalleri D, Gianetta E, Friedman D,Scopinaro N. In vivo evaluation of immunological status after biliopancreatic bypass for obesity. Int J Obes 1985; 9: 171-5.

115. Hanusch-Enserer U, Cauza E, Spak M, Dunky A, Rosen HR, Wolf H, Prager R, Eibl MM. Acute-phase response and immunological markers in morbid obese patients and patients following adjustable gastric banding. Int J Obes Relat Metab Disord 2003; 27: 355-61.

116. Dixon JB, O'Brien PE. Obesity and the white blood cell count: changes with sustained weight loss. Obes Surg 2006; 16: 251-7.

117. van Dielen FM, Buurman WA, Hadfoune M, Nijhuis J, Greve JW. Macrophage inhibitory factor, plasminogen activator inhibitor-1, other acute phase proteins, and inflammatory mediators normalize as a result of weight loss in morbidly obese subjects treated with gastric restrictive surgery. J Clin Endocrinol Metab 2004; 89: 4062-8.

118. Kyzer S, Binyamini J, Chaimoff C, Fishman P. The effect of surgically induced weight reduction on the serum levels of the cytokines: interleukin-3 and tumor necrosis factor. Obes Surg 1999; 9: 229-34.

119. Hu MG, Zheng CZ, Ke CW, Yin K, Li JH, Hu B, Wu YF, Cao P, Zou DJ, Zhang J. Effect of weight loss induced by laparoscopic adjustable gastric banding on immunity of morbid obesity [resumo]. Zhonghua Wai Ke Za Zhi 2005; 43: 309-12.

120. Stocker DJ. Management of the bariatric surgery patient. Endocrinol Metab Clin North Am 2003; 32: 437-57. 
121. Alvarez-Leite JI. Nutrient deficiencies secondary to bariatric surgery. Curr Opin Clin Nutr Metab Care 2004; 7: 569-75.

122. Manco M, Fernadez-Real JM, Equitani F, Vendrell J, Mora MEV, Nanni $G$ et al. Effect of massive weight loss on inflammatory adipocytokines and the innate immune system in morbidly obese women. J Clin Endocrinol Metab 2007; 92: 483-90.

123. McAuliffe PF, Efron PA, Scumpia PO, Uchida T, Mutschlecner SC, Rout WR, Moldawer LL, Cendan JC. Varying blood monocyte and dendritic cell responses after laparoscopic versus open gastric bypass surgery. Obes Surg 2005; 15: 1424-31.

124. Vilarrasa N, Vendrell J, Sánchez-Santos R, Broch M, Megia A, Masdevall C, Gómez N, Soler J, Pujol J, Bettónica C, Aranda H, Gómez JM. Effect of weight loss induced by gastric bypass on proinflammatory interleukin-18, soluble tumour necrosis factor-alpha receptors, C-reactive protein and adiponectin in morbidly obese patients. Clin Endocrinol 2007; 67: 679-86.

125. Cottam DR, Schaefer PA, Fahmy D, Shaftan GW, Angus LD. The effect of obesity on neutrophil Fc receptors and adhesion molecules (CD16, CD11b, CD62L). Obes Surg 2002; 12: 230-5.

126. Fontana L, Eagon JC, Colonna M, Klein S. Impaired mononuclear cell immune function in extreme obesity is corrected by weight loss. Rejuvenation Res 2007; 10: 41-6. 
127. Ahren S, Mansson RL Gingerich PJ, Havel. Regulation of plasma leptin in mice: influence of age, high-fat diet, and fasting. Am J Physiol Regul Integr Comp Physiol 1997, 273: R113-20.

128. Nijhuis J, van Dielen FMH, Buurman WA, Greve JWM. Leptin in morbidly obese patients: no role for treatment of morbid obesity but important in the postoperative immune response. Obes Surg 2004; 14 : 476-83.

129. Chan JL, Bullen J, Stoyneva V, Depaoli AM, Addy C, Mantzoros CS. Recombinant methionyl human leptin administration to achieve high physiologic or pharmacologic leptin levels does not alter circulating inflammatory marker levels in humans with leptin sufficiency or excess. J Clin Endocrinol Metab 2005; 90: 1618-24.

130. Shuster MH, Vazquez JA. Nutritional concerns related to Roux-en-Y gastric bypass: what every clinician needs to know. Crit Care Nurs $Q$ 2005; 28: 227-60.

131. Dietary Reference Intakes [on line]. Dietary Guidance: Food and Nutrition Information Center of United States, Department of Agriculture. National Academy of Sciences; 2004. Disponível em: http://www.iom.edu/Object.File/Master/21/372/0.pdf.

132. Korzeniewski C, Callewaert DM. An enzyme-release assay for natural cytotoxicity. J Immunol Methods 1983; 64: 313-20.

133. Kotidis EV, Koliakos GG, Baltzopoulos VG, loannidis KN, Yovos JG, Papavramidis ST. Serum ghrelin, leptin and adiponectin levels before 
and after weight loss: comparison of three methods of treatment--a prospective study. Obes Surg 2006; 16: 1425-32.

134. Rudd PM, Elliott T, Cresswell P, Wilson IA, Dwek RA. Glycosylation and the immune system. Science 2001; 291: 2370-6.

135. Mol MJ, Demacker PN, Stalenhoef AF. The role of modification of lipoproteins and of the immune system in early atherogenesis. Neth $\mathrm{J}$ Med 1993; 43: 83-90.

136. Maggard MA, Shugarman LR, Suttorp M, Maglione M, Sugerman HJ, Livingston EH, Nguyen NT, Li Z, Mojica WA, Hilton L, Rhodes S, Morton SC, Shekelle PG. Meta-analysis: surgical treatment of obesity. Ann Intern Med 2005; 142: 547-59.

137. Shah M, Simha V, Garg A. Review: long-term impact of bariatric surgery on body weight, comorbidities, and nutritional status. J Clin Endocrinol Metab 2006; 91: 4223-31.

138. Geloneze B, Tambascia MA, Pareja JC, Repetto EM, Magna LA, Pereira SG. Serum leptin levels after bariatric surgery across a range of glucose tolerance from normal to diabetes. Obes Surg 2001; 11: 693-8.

139. Zabrocka L, Raczynska S, Goyke E, Sledzinski Z, Swierczynski J. BMI is the main determinant of the circulating leptin in women after vertical banded gastroplasty. Obes Res 2004; 12: 505-12.

140. Toornvliet AC, Pijl H, Frölich M, Westendorp RG, Meinders AE. Insulin and leptin concentrations in obese humans during long-term weight loss. Neth J Med 1997; 51: 96-102. 
141. Parkes E. Nutritional management of patients after bariatric surgery. Am J Med Sci 2006; 331: 207-13.

142. Bastard JP, Jardel C, Bruckert E, Blondy P, Capeau J, Laville M, Vidal $\underline{\mathrm{H}}$, Hainque $\mathrm{B}$. Elevated levels of interleukin 6 are reduced in serum and subcutaneous adipose tissue of obese women after weight loss. J Clin Endocrinol Metab 2000; 85: 3338-42.

143. Ziccardi P, Nappo F, Giugliano G, Esposito K, Marfella R, Cioffi M, D'Andrea F, Molinari AM, Giugliano D. Reduction of inflammatory cytokine concentrations and improvement of endothelial functions in obese women after weight loss over one year. Circulation 2002; 105: 804-9.

144. Mohamed-Ali V, Goodrick S, Rawesh A, Katz DR, Miles JM, Yudkin JS, Klein S, Coppack SW. Subcutaneous adipose tissue releases interleukin-6, but not tumor necrosis factor-alpha, in vivo. J Clin Endocrinol Metab 1997; 82: 4196-200.

145. O'Rourke RW, Kay T, Lyle EA, Traxler SA, Deveney CW, Jobe BA, Roberts Jr CT, Marks D, Rosenbaum JT. Alterations in peripheral blood lymphocyte cytokine expression in obesity. Clin Exp Immunol 2006; 146: 39-46.

146. Anderson P. Post-transcriptional regulation of tumor necrosis factor $\alpha$ production. Ann Rheum Dis 2000; 59 (suppl I): i3-i5.

147. Lopez-Botet M, Fontan G, Garcia Rodriguez MC, de Landazuri MO. Relationship between IL 2 synthesis and the proliferative response to 
PHA in different primary immunodeficiencies. J Immunol 1982; 128: 679-83.

148. Nieman DC, Henson DA, Gusewitch G, Warren BJ, Dotson RC, Butterworth DE, Nehelsen-Cannarella SL. Physical activity and immune function in elderly women. Med Sci Sports Exerc 1993; 25: 823-31.

149. Dovio A, Caramello V, Masera RG, Sartori ML, Saba L, Tinivella M, Prolo P, Termine A, Avagnina P, Angeli A. Natural killer cell activity and sensitivity to positive and negative modulation in uncomplicated obese subjects: relationships to leptin and diet composition. Int J Obes 2004; 28: 894-901.

150. Zamai L, Zauli G, Bavelloni A, Marmiroli S, Cataldi A, Weber G, Vitale M. Tiazofurin induces a down-modulation of ICAM-1 expression on K562 target cells impairing NK adhesion and killing. Cell Immunol 1995; 164: 100-4.

151. Nagatake H, Watanabe N, Kobayashi $\mathrm{Y}$. Granule exocytosis in a cultured human natural killer cell-rich population induced by K562 target cells and by PMA/A23187. Cell Immunol 1995; 161: 295-8.

152. Mito N, Yoshino H, Hosoda T, Sato K. Analysis of effect of leptin on immune function in vivo using diet-induced obese mice. $\mathrm{J}$ Endocrinol 2003; 180: 167-73.

153. Nave H, Mueller G, Siegmund B, Jacobs R, Stroh T, Schueler U, Hopfe M, Behrendt P, Buchenauer T, Pabst R, Brabant G. Resistance of JAK-2 dependent leptin signaling in NK cells- a novel mechanism of 
NK cell dysfunction in diet-induced obesity. Endocrinology 2008; 149: 3370-8.

154. Papathanassoglou E, El-Haschimi K, Li XC, Matarese G, Strom T, Mantzoros C. Leptin receptor expression and signaling in lymphocytes: kinetics during lymphocyte activation, role in lymphocyte survival, and response to high fat diet in mice. $\mathrm{J}$ Immunol 2006; 176: 7745-52.

155. Wolowczuk I, Verwaerde C, Viltart O, Delanoye A, Delacre M, Pot B, Grangette C. Feeding our immune system: impact on metabolism. Clin Dev Immunol 2008; 639803: 1-19.

156. Dixit VD. Adipose-immune interactions during obesity and caloric restriction: reciprocal mechanisms regulating immunity and health span. J Leukoc Biol 2008; 84: 1-11.

157. Albanes D. Total calories, body weight and tumor incidence in mice. Cancer Res 1987; 47: 1987-92.

158. Hursting SD, Lavigne JA, Berrigan D, Perkins SN, Barrett JC. Calorie restriction, aging, and cancer prevention: mechanisms of action and applicability to humans. Annu Rev Med. 2003; 54: 131-52.

159. Renehan AG, Tyson M, Egger M, Heller RF, Zwahlen M. Body-mass index and incidence of cancer: a systematic review and meta-analysis of prospective observational studies. Lancet 2008; 371:569-78.

160. Smith AG, Sheridan PA, Harp JB, Beck MA. Diet-induced obese mice have increased mortality and altered immune responses when infected with influenza virus. J Nutr 2007; 137: 1236-43. 